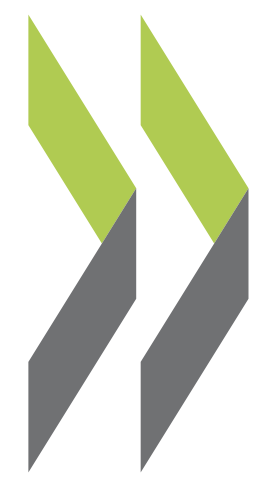

OECD Economics Department Working Papers No. 1136

Long-term Patterns of Trade and Specialisation

Asa Johansson, Eduardo Olaberría 
Organisation de Coopération et de Développement Économiques

Organisation for Economic Co-operation and Development

04-Jul-2014

ECONOMICS DEPARTMENT

English - Or. English

LONG-TERM PATTERNS OF TRADE AND SPECIALISATION

ECONOMICS DEPARTMENT WORKING PAPERS No. 1136

By Åsa Johansson and Eduardo Olaberria

OECD Working Papers should not be reported as representing the official views of the OECD or of its member countries. The opinions expressed and arguments employed are those of the author(s).

Authorised for publication by Jean-Luc Schneider, Deputy Director, Policy Studies Branch, Economics Department.

All Economics Department Working Papers are available through OECD's internet website at www.oecd.org/eco/workingpapers

JT03360166

Complete document available on OLIS in its original format

This document and any map included herein are without prejudice to the status of or sovereignty over any territory, to the delimitation of international frontiers and boundaries and to the name of any territory, city or area. 
ECO/WKP(2014)32

OECD Working Papers should not be reported as representing the official views of the OECD or of its member countries. The opinions expressed and arguments employed are those of the author(s).

Working Papers describe preliminary results or research in progress by the author(s) and are published to stimulate discussion on a broad range of issues on which the OECD works.

Comments on Working Papers are welcomed, and may be sent to OECD Economics Department, 2 rue André-Pascal, 75775 Paris Cedex 16, France, or by e-mail to eco.contact@oecd.org

This document and any map included herein are without prejudice to the status of or sovereignty over any territory, to the delimitation of international frontiers and boundaries and to the name of any territory, city or area.

\section{(c) OECD (2014)}

You can copy, download or print OECD content for your own use, and you can include excerpts from OECD publications, databases and multimedia products in your own documents, presentations, blogs, websites and teaching materials, provided that suitable acknowledgment of OECD as source and copyright owner is given. All requests for commercial use and translation rights should be submitted to rights@oecd.org 


\section{ABSTRACT/RÉSUME}

\section{Long-term patterns of trade and specialisation}

This paper presents descriptive evidence of specialisation trends and investigates empirically their causes and consequences, analysing the role of policies in this process. Then, based on the insights from the backward looking analysis, it draws global trade and specialisation scenarios up to 2060, taking into account international spillovers. The paper highlights that comparative advantage in terms of factor endowments matters for trade specialisation, although framework and trade policies also play a role. For instance, tariffs on intermediate inputs are found to adversely affect trade with this adverse effect found to have increased over time, likely reflecting expanding global supply chains magnifying the impact of tariffs. The forward-looking analysis suggests that over the next 50 years, the geographical centre of trade will continue to shift from OECD to non-OECD regions, reflecting faster growth in these countries. Multilateral global trade liberalisation could raise world trade by $15 \%$ by 2060 relative to the status quo, whereas regional liberalisation among a core group of OECD countries only would raise world trade by $4 \%$ due to trade diversion.

\section{JEL classification codes: F13; F14; F17; F43; F60.}

Keywords: Long-term trade and specialisation patterns, trade liberalisation, trade policy, intermediate input tariffs, global value chains.

$* * * * * * * * * * * * * * *$

\section{Profils des échanges mondiaux et de la spécialisation}

Ce rapport présente des données descriptives concernant les tendances en matière de spécialisation et examine empiriquement ses causes et conséquences tout en analysant le rôle des politiques publiques à cet égard. À partir des enseignements tirés de l'analyse rétrospective, il établit ensuite des scénarios d'échanges mondiaux et de spécialisation jusqu'en 2060 en tenant compte des retombées internationales qu'ils pourraient avoir. Le rapport souligne que la spécialisation commerciale dépend de l'avantage comparatif que représente la dotation en facteurs de production, bien que les politiques générales et les politiques commerciales aient aussi leur importance. Par exemple, les droits de douane prélevés sur les biens intermédiaires s'avèrent préjudiciables aux échanges, cet effet s'accentuant au fil des ans. Cette évolution témoigne vraisemblablement du fait que le développement des chaînes d'approvisionnement mondiales amplifie l'incidence des droits de douane. L'analyse prospective laisse supposer qu'au cours des cinquante prochaines années, le centre géographique des échanges s'éloignera encore des pays de l'OCDE au profit de pays d'autres régions dont la croissance s'accélèrera. La libéralisation des échanges mondiaux multilatéraux pourrait entrâner une augmentation des échanges mondiaux de 15 \% d'ici 2060 par rapport à la situation actuelle tandis que la hausse induite par la libéralisation régionale dans un groupe composé des grands pays de l'OCDE ne serait que de $4 \%$ en raison de la réorientation des courants d'échanges.

Classification JEL : F13; F14; F17; F43; F60.

Mots-clés : Profils des échanges et de la spécialisation à long terme, libéralisation des échanges, droits de douanes sur les biens intermédiaires, chaînes de valeur mondiales. 


\section{TABLE OF CONTENTS}

LONG-TERM PATTERNS OF TRADE AND SPECIALISATION ..................................................... 6

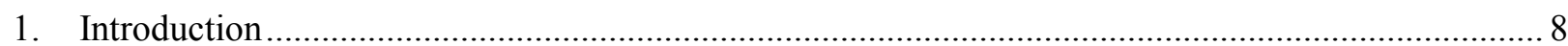

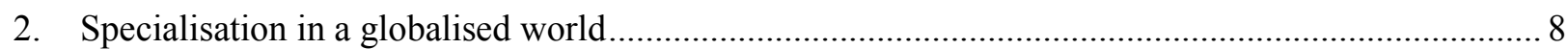

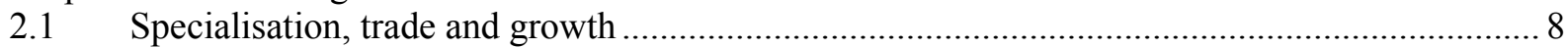

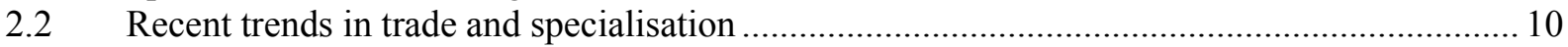

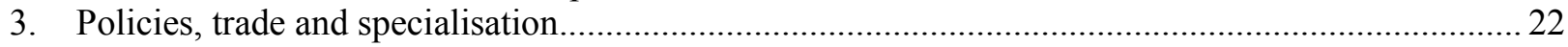

3.1 Unbundling of production can magnify the adverse effect of tariffs ........................................2 23

3.2 Sound public institutions can enhance trade in industries with long value chains....................24

3.3 Financial development can alleviate cash constraints and facilitate trade and growth.............26

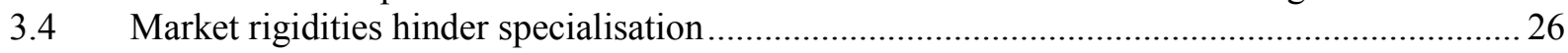

3.5 Raising skills can facilitate knowledge-intensive specialisation and affect inequality ............27

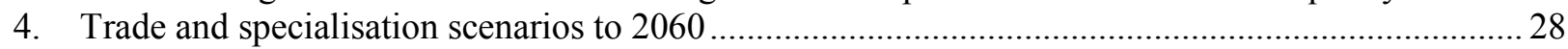

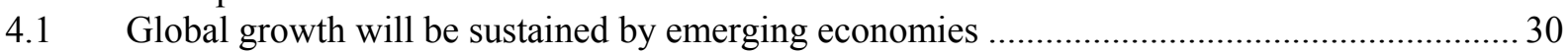

4.2 Continuing globalisation over the next half century ........................................................... 31

4.3 Globalisation and income convergence will influence trade and industrial specialisation....... 32

4.4 Income convergence will influence wage inequality among and within countries....................34

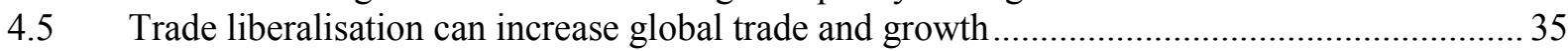

4.6 The speed of up-skilling in emerging economies influences trade and specialisation.............. 42

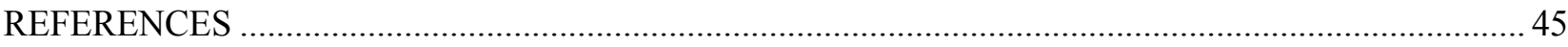

APPENDIX 1: DETERMINANTS OF TRADE IN VALUE-ADDED .................................................. 51

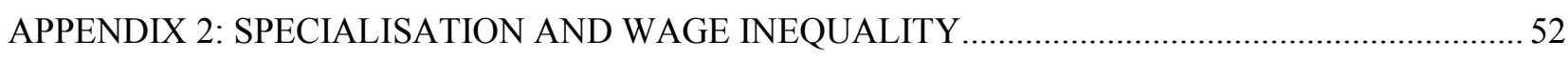

APPENDIX 3: POLICY ASSUMPTIONS IN THE BASELINE ............................................................ 54

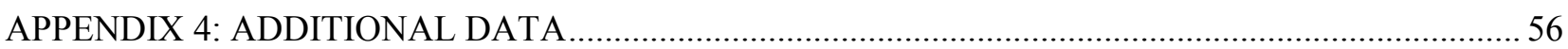

\section{Tables}

Appendix Table 1. Determinants of gross exports and value-added exports ........................................ 51

Appendix Table 2. Determinants of gross exports and value-added exports ...................................... 53

\section{Figures}

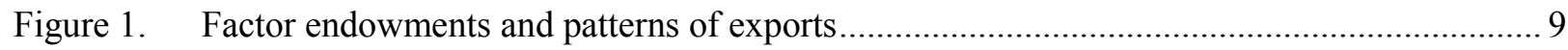

Figure 2. Trade has increased rapidly in China and India ................................................................ 11

Figure 3. Value-added in gross exports varies across countries and industries................................. 13

Figure 4. The number of foreign production stages in the supply chain varies across industries ........ 14

Figure 5. Final demand developments implied that demand for high-skill labour rose across most ... 17

Figure 6. Contribution of broad sectors to the change in demand for skills, 1995-2008, \% .............. 17

Figure 7. Change in number of jobs due to technology, trade and consumption, 1995-2008 (thousands) ${ }^{1}$

Figure 8. Proximate determinants of the change in number of jobs by skills in electronics and market services 
Figure 9. Impact of specialisation and supply of skills on wage gaps between skilled and unskilled

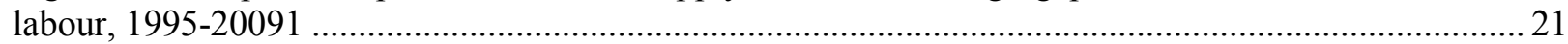

Figure 10. Cuts in tariffs on key intermediate inputs boost trade in the same and in downstream

industry ${ }^{1}$

Figure 11. Policies and institutions influence trade......................................................................2

Figure 12. Policies and institutions influence industrial value-added shares ...................................2 27

Figure 13. Major changes in the composition of world output over the next 50 years ..................... 30

Figure 14. The geographical distribution of trade will shift.......................................................... 31

Figure 15. A growing share of trade will occur between different non-OECD countries.................. 32

Figure 16. The relative importance of different countries in specific industries are expected to

change ${ }^{1}$

Figure 17. Industrial structure is set to change in emerging economies......................................... 34

Figure 18. Unevenly distributed increases in trade in liberalisation scenarios, 2060....................... 37

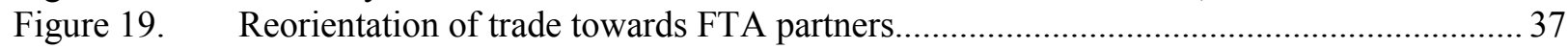

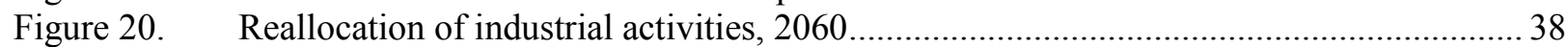

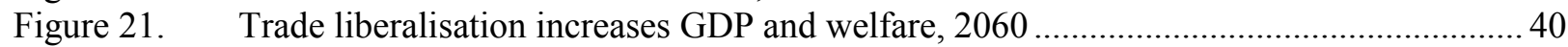

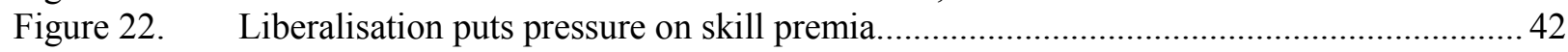

Figure 23. Effects on trade of lower up-skilling in emerging economies, 2060 ............................. 43

Figure 24. Slower up-skilling in emerging economies slows down their restructuring towards higher

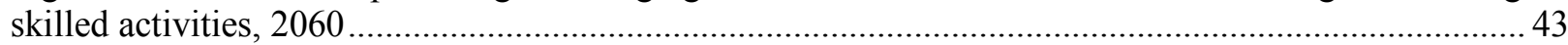

Appendix Figure 1: Trade shares in selected industries, 2010 and 2060 ............................................ 56

\section{Boxes}

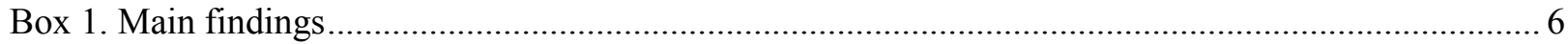

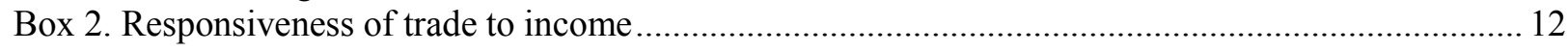

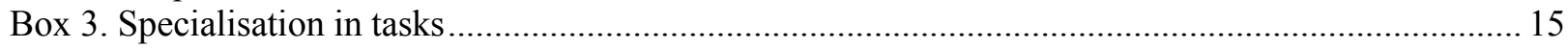

Box 4. Demand for different skills within a global supply chain...................................................... 16

Box 5. Empirical approach used to study wage gaps between skilled and unskilled workers .................. 21

Box 6. Empirical approaches for identifying determinants of specialisation ...........................................22

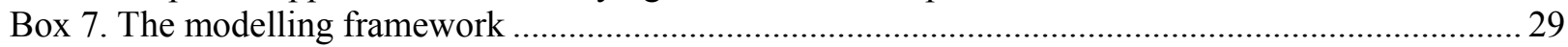

Box 8. Assumptions in the alternative trade policy scenarios ................................................................. 36 


\title{
LONG-TERM PATTERNS OF TRADE AND SPECIALISATION
}

\author{
By \\ Åsa Johansson and Eduardo Olaberria ${ }^{1}$
}

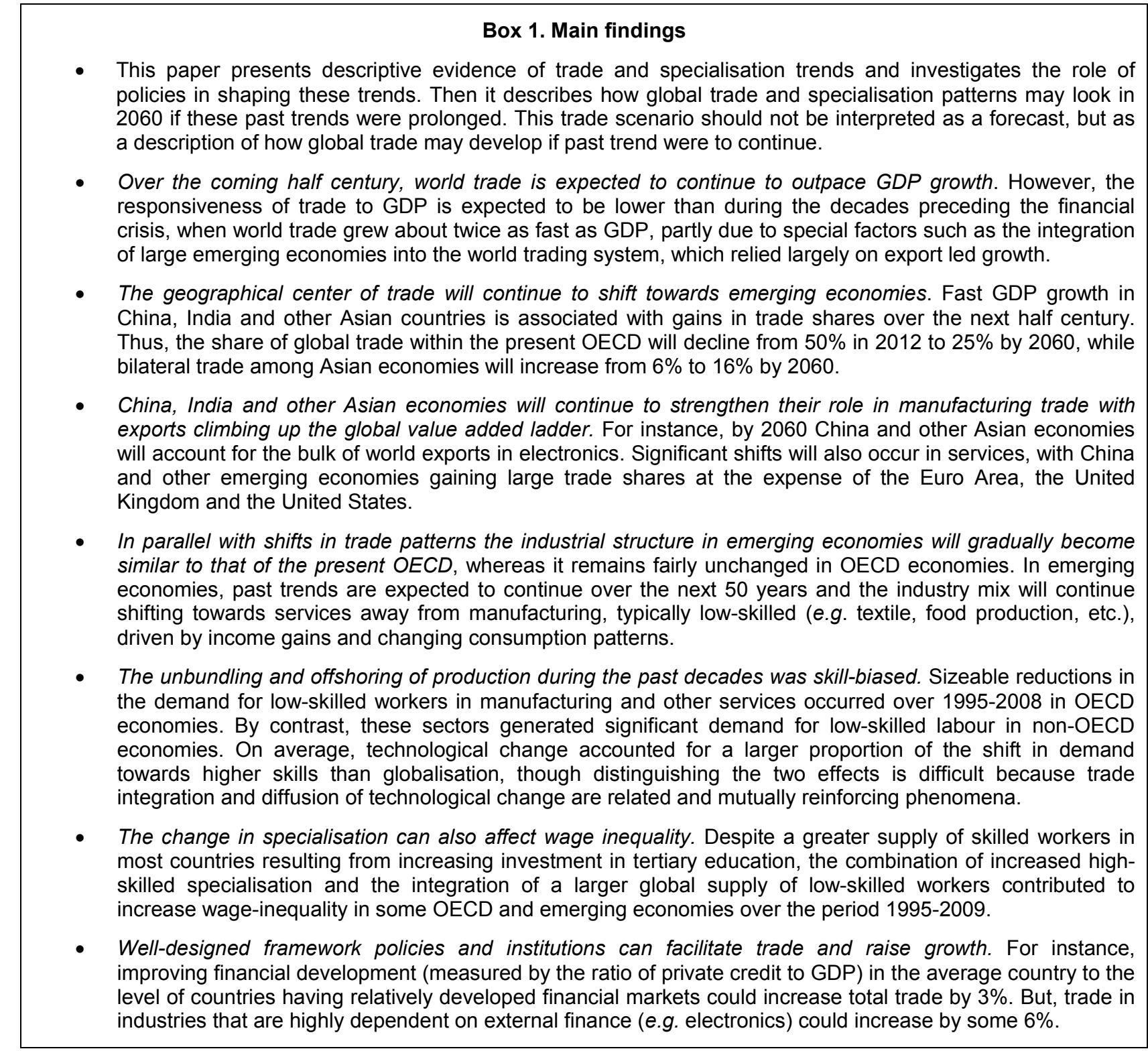

1. Asa Johansson and Eduardo Olaberria work at the OECD Economics Department. The authors would like to thank Jean Château, Jorgen Elmeskov, Giuseppe Nicoletti, Frank van Tongeren, Dave Turner and JeanLuc Schneider for their valuable comments and suggestions and Sarah Michelson for excellent editorial support. The paper has also benefited from comments by members of Working Party No. 1 of the OECD Economic Policy Committee. This paper has benefitted from collaborative work with the Centre d'Etudes Prospectives et d'Informations Internationales (CEPII) and the Trade and Agricultural Directorate at the OECD. 
- $\quad$ Policies that try to promote trade and growth of specific industries by tariffs or quotas can cause waste and be increasingly counter-productive in the context of trade integration and expanding value chains. For instance, tariffs can raise the cost of intermediate inputs affecting relative productivity and reducing trade. This effect is particularly strong in industries characterised by long global supply chains, such as electronics and the auto industry.

- Gradually removing tariffs, regulatory barriers in services and agricultural support, as well as reducing transaction costs on goods (e.g. costs of handling at customs) could increase global trade and GDP over the next 50 years. Specific scenarios of regional or partial multilateral liberalisation among a core group of OECD countries could, respectively, raise trade by $4 \%$ and $15 \%$ and GDP by $0.6 \%$ and $2.8 \%$ by 2060 relative to the status quo, with the effects on GDP being larger if the feedback of increased openness for technological diffusion is taken into account. However, the gains would be distributed unevenly across countries. Regional liberalisation would bring greater gains to members of the free-trade agreement, notably OECD countries, rather than to non-members, due to trade diversion.

- Investment in education is crucial for trade and high-skill specialisation patterns over the coming decades. In fact, slower educational upgrading in key emerging economies (i.e. China, India and Indonesia) than expected in the baseline scenario could reduce world exports by $2 \%$ by 2060 , with decreases ranging between $6-11 \%$ in China, India and Indonesia. Lower up-skilling in emerging economies would also slowdown the restructuring towards higher value-added activities in these emerging economies. 


\section{Introduction}

1. Global trade is undergoing rapid change through a fragmentation of production processes and the integration of emerging economies into the global market. These trends are affecting trade and industrial specialisation, demand for skills and relative wages, bringing benefits and creating new policy challenges. This paper presents descriptive evidence of specialisation trends and investigates empirically their causes and consequences, analysing the role of policies in this process. Then, based on the insights from the backward looking analysis, it draws global trade and specialisation scenarios up to 2060, taking into account international spillovers.

2. The paper is structured as follows. Section 2 sketches a framework linking trade, specialisation, growth and wages of different categories of workers. It then discusses key stylised trade and specialisation trends and their implications for economic performance, including demand for skills and inequality developments. Section 3 explores the role that public policies have in influencing trade and industrial structure. Based on the insights from previous sections, Section 4 draws future specialisation scenarios relying on a detailed multi-country sectoral general equilibrium trade model calibrated on the OECD longterm projections for the world economy. Finally, scenarios based on alternative trade policy and skill developments are also explored.

\section{Specialisation in a globalised world}

\subsection{Specialisation, trade and growth}

3. Trade can increase growth and raise aggregate welfare in various ways:

- It induces a more efficient allocation of resources across firms and sectors and this reallocation generates efficiency gains. It also raises competitive pressures, and thereby reduces $\mathrm{x}$ inefficiencies and stimulates innovation (Aghion and Howitt, 1998).

- It facilitates access to larger international markets, bringing about economies of scale and generating technological and knowledge spillovers with positive implications for growth (e.g. River-Batiz and Romer, 1991, Dalum et al., 1999).

- It enables countries to specialise in a narrow range of goods and labour to specialise in certain tasks in which the country has a comparative advantage leading to higher productivity growth in the form of learning and scale effects (e.g. Krugman, 1980).

4. However, the benefits of trade are not equally distributed across and within countries. Trade encourages countries to specialise and since different goods and activities are associated with different technological and learning opportunities, those that specialise in dynamic and innovative industries are in a better position to achieve sustained economic growth than others (Grossman and Helpman, 1991; Hausmann et al., 2007; Amable, 2000).

5. The products in which countries specialise are determined in part by the availability of inputs used in the manufacture of different products and access to different technologies. For example, for a given technology, specialisation is driven by differences in relative factor endowments (i.e. Heckscher-Ohlin; OECD, 2011a). Indeed, estimates suggest, for instance, that a country that is capital rich (i.e. at the $75^{\text {th }}$ percentile of the cross-country distribution of capital per worker) will export around $12 \%$ more of all products when compared with a country at the median position of capital per worker (Figure 1A). But, exports of products that are capital-intensive (such as chemicals and plastics) can increase by around $25 \%$ (Figure 1B and Johansson et al., (2014) and Box 6). 
Figure 1. Factor endowments and patterns of exports

A. Effect of a change in factor endowments on total exports ${ }^{1}$

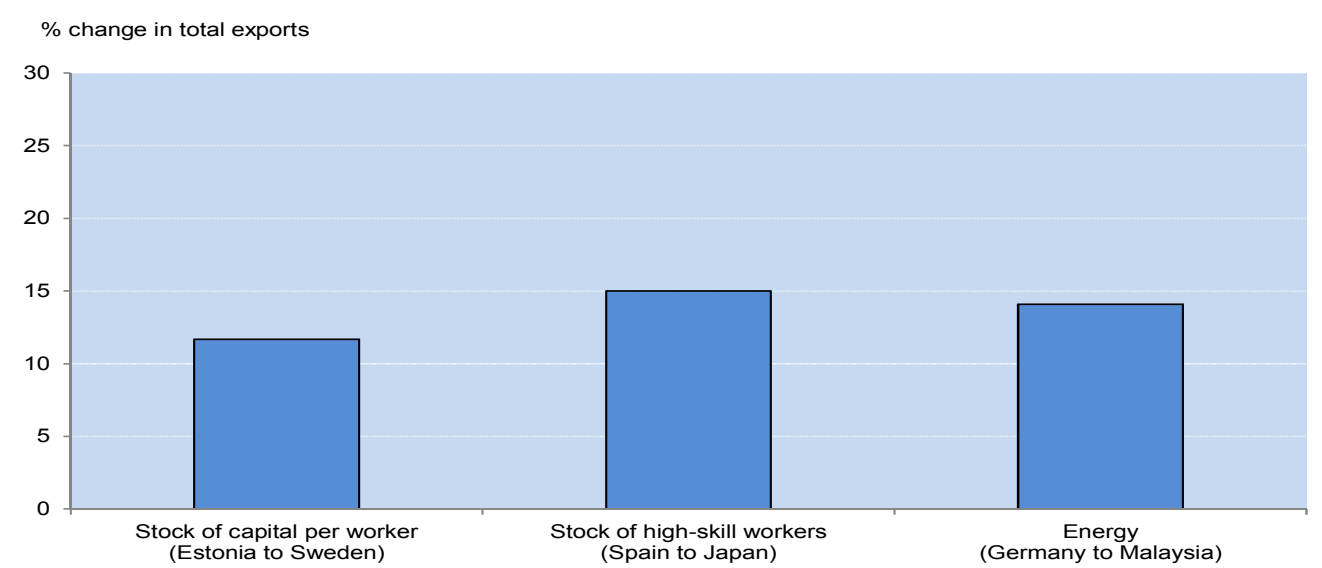

B. Effect of a change in factor endowments on exports of goods that are intensive in such factors ${ }^{1,2}$

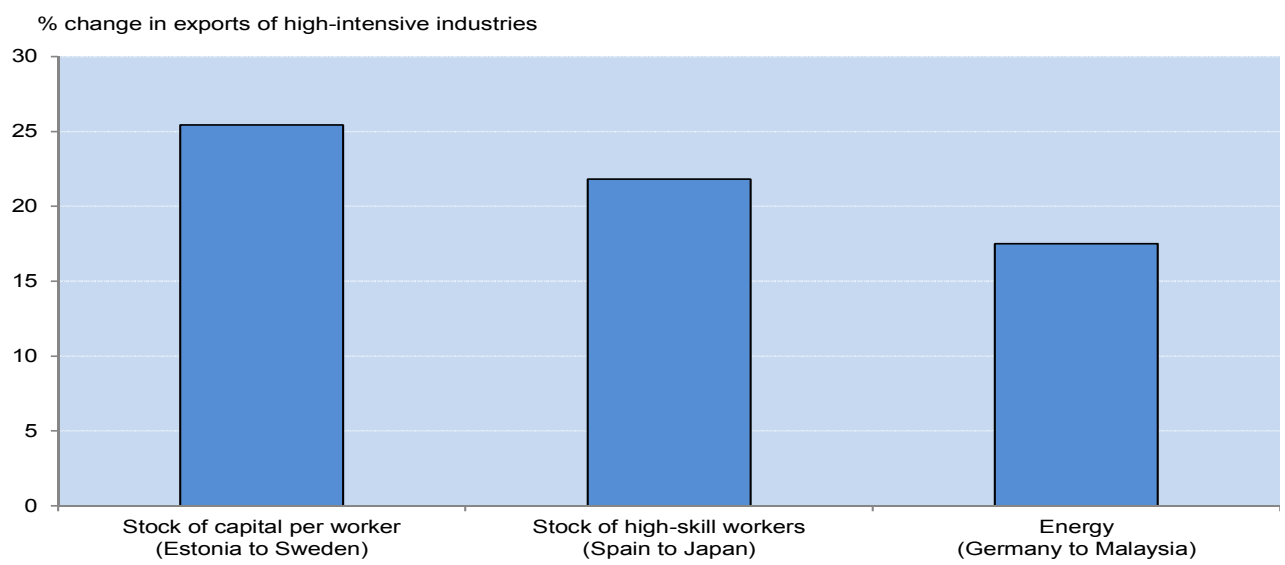

1. For each factor of production the figures show the percentage difference in gross exports between the country at the $75^{\text {th }}$ percentile of the cross-country distribution of the relevant production factor among the countries included in the sample and the country at the median level of the cross-country distribution of the factor. The size of the change in the stock of capital per worker corresponds to a move from the level in Estonia to the level in Sweden, the change in human capital corresponds to a move from the level in Spain to the level in Japan, and the change in energy to a move from the level in Germany to the level in Malaysia.

2. In this figure products are termed intensive if they are at the $90^{\text {th }}$ percentile of intensity in the distribution of the specific factor endowment.

Source: OECD calculations.

6. Besides factor endowments, public policies and institutions can influence trade and specialisation:

- They can affect trade and specialisation by altering the incentives for accumulation of production factors and technological innovation.

- Since industries differ in their need for well-functioning institutions and regulations to support production, cross-country differences in institutional settings will influence competitiveness by affecting relative productivity (Chor, 2010; Nunn and Trefler, 2013). For instance, well- 
functioning financial markets matter relatively more for industries that require external financing for investment than for other industries.

- Specific industrial and trade policies (e.g. tariffs) can facilitate growth of domestic industries by enabling the development of economies of scale. But they can create trade diversion by changing relative prices and influence specialisation and trade.

- Domestic policies and institutions create spill-overs to trading partners by changing countries' relative productivity in producing different goods (e.g. Helpman and Itskhoki, 2010). Domestic policies also affect trading partners via income and demand effects (Felbermayr et al., 2009). Finally, in an integrated global value chain, changes in policies that affect relative productivity generate cross-country spillovers by affecting the whole chain of suppliers through production linkages (Koopman et al., 2010; OECD, 2012b).

7. Changes in specialisation patterns can have implications for inequality by shifting the demand from one factor of production to another, leading to changes in relative wages across and within skill categories. By implication, public policies can influence the wage gap between skilled and un-skilled workers at home and abroad. For instance, policies that enhance access to higher education for a wider group of individuals can mitigate a rising wage gap in an environment characterised by increasing demand for high-skilled workers. Such policies could also generate spillovers to foreign countries by affecting relative wages of skilled to unskilled and trade patterns across countries.

\subsection{Recent trends in trade and specialisation}

8. Over the past decades economic integration increased and world trade intensified. World trade grew faster than world GDP, particularly after 1990, indicating that the responsiveness of trade to GDP increased - some studies suggest that the elasticity rose to above 3 after mid-1980s from around 1.5 in the earlier years (Freund, 2009; Box 2). The surge in world trade was partly driven by the integration of China and India into world markets. The growth of trade was significantly higher in China and India than globally and in OECD countries (Figure 2). This rapid growth in trade was matched by a shift in market shares in world trade from OECD economies towards some emerging economies. Over 1985 to 2008, China's share in world exports of goods increased from $2 \%$ to nearly $10 \%$ and India's market share doubled, though from low initial levels, whereas it more than halved in some OECD countries (e.g. Japan and the United Kingdom). 
Figure 2. Trade has increased rapidly in China and India

A. Annual growth of exports of goods and services and annual growth in world GDP (5-year moving averages), \%

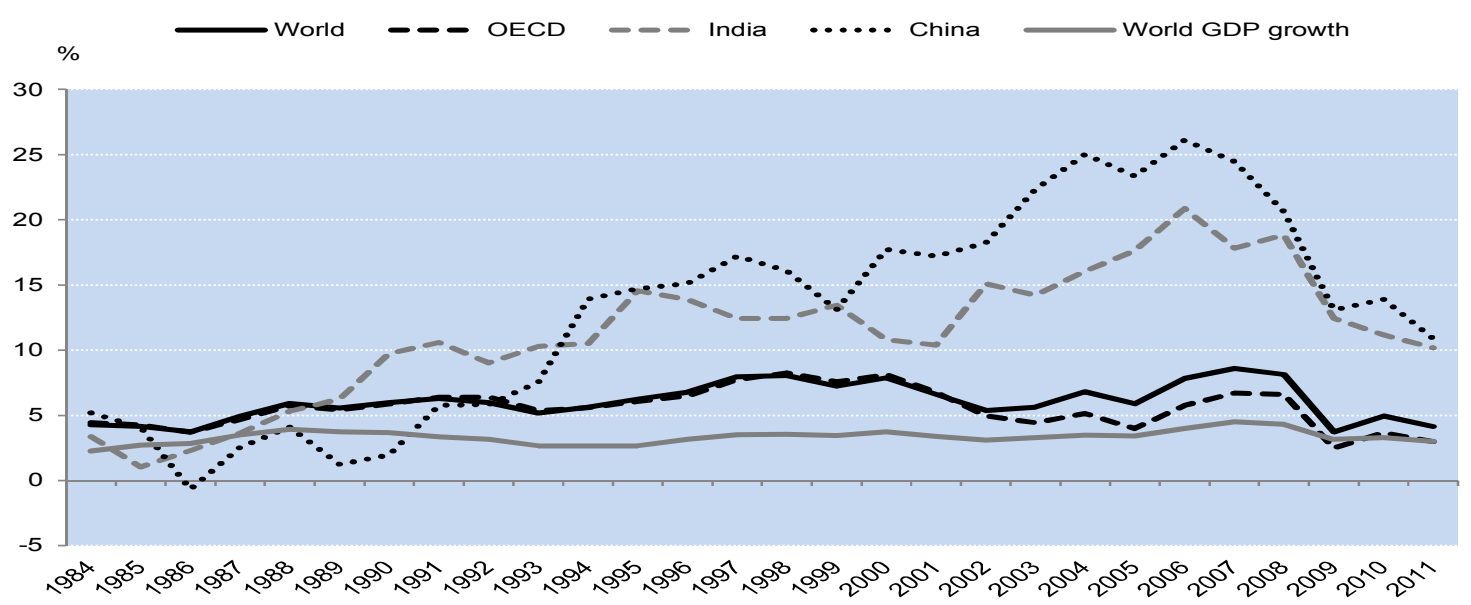

B. Market share in world exports, 1985 and $2008, \%$

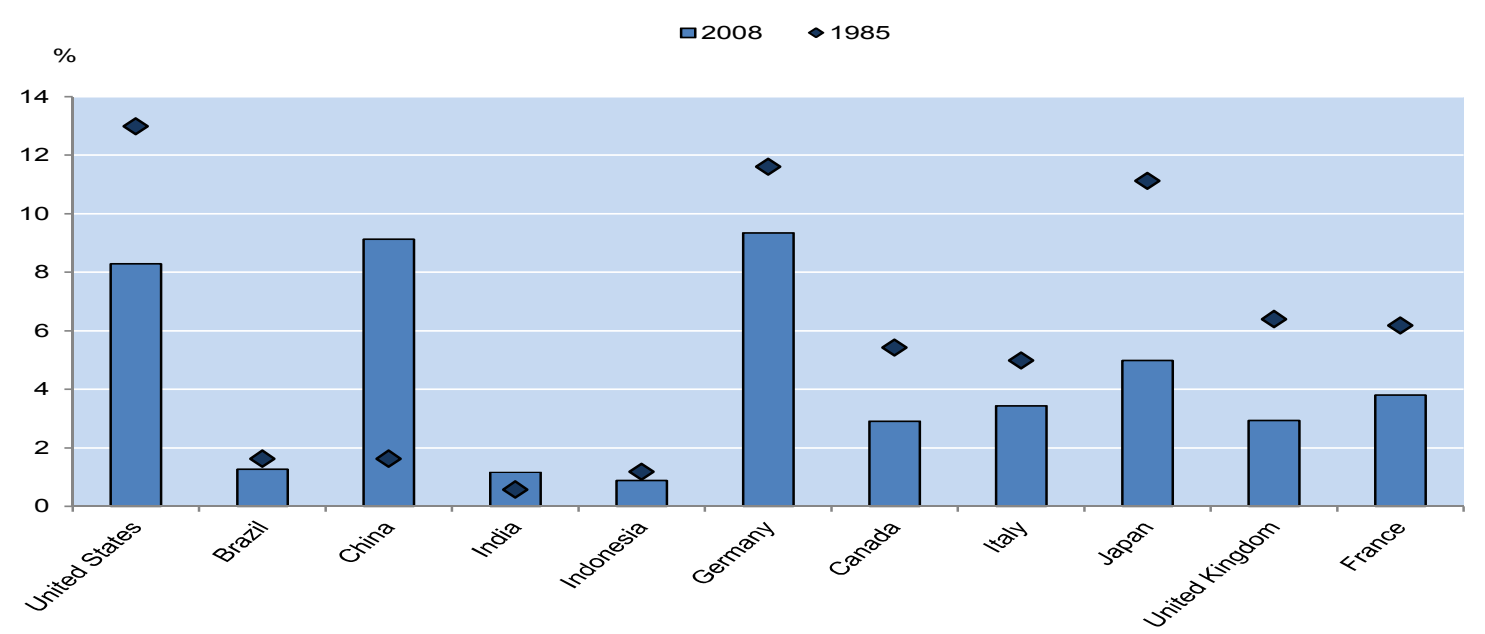

Source: World Bank development indicators and OECD Trade indicators database.

9. One major event contributing to the rapid increase in trade during the last decade was the opening up of China's market to international trade following its membership in WTO in 2001, with associated reductions in trade barriers. Generally, the easing of trade barriers and technological improvements in transportation and communication facilitated trade integration (OECD, 2003; OECD, 2005; Hummels, 2007). ${ }^{2}$ Since the early 1990 s regional trade agreements have become increasingly prevalent with many countries having signed bilateral or multilateral trade agreements. Indeed, evidence shows that countries export on average about $65 \%$ more to countries with which they have a trade agreement than to other countries and after controlling for other influences (See Johansson et al., 2014 for details). ${ }^{3}$ In parallel with

2. Transportation costs are typically estimated to be higher than tariffs (Andersson and van Wincoop, 2004; Moïse and Bris, 2013), but due to data limitations it is difficult to measure them directly for a large set of countries. Recent OECD data on maritime transport costs suggest that they vary widely among commodities and trade routes and are particularly high for some agricultural products (Korniek and Sourdin, 2010).

3. The estimated impact of regional trade agreements on trade may be upward biased due to endogeneity problems (e.g. Egger et al., 2011), thus the magnitude of the results should be interpreted with caution. 
the implementation of trade agreements, tariffs were reduced in both developed and developing countries with a positive effect on trade. Estimates suggest that, when tariffs on goods are cut by 5 percentage points, trade increases by around 7\% (see Johansson et al., 2014). A recent OECD study found that policies aimed at facilitating trade by reducing hurdles in international trade procedures (e.g. formalities and procedures, fees and charges, advance rulings, etc.) can boost gross trade (Moïse et al., 2011).

\section{Box 2. Responsiveness of trade to income}

The relationship between trade and GDP has been the focus of an intense debate in recent years. Between 1970 and 2008, the share of world trade in world GDP increased significantly (Figure below). A more rapid growth in trade than GDP indicates that the responsiveness of trade with respect to income is greater than one. There are different hypotheses for the high responsiveness of trade to GDP heading up to the financial crisis, notably:

- Integration of emerging economies: Integration of large emerging economies (e.g. China) into the world trading system, which relied largely on export led growth, temporarily increased the trade-to-GDP elasticity.

- Global value chains: Ongoing geographical fragmentation of production chains with increased sourcing of foreign intermediate inputs increased global trade (Escaith et al, 2010).

During the recent financial crisis, the responsiveness of trade to GDP dropped sharply. It recovered after 2009 but remained flat over the past two years. A series of hypotheses for the slowing in the responsiveness prevail:

- Temporary shocks: Natural disasters in Japan and Thailand, as well as tensions between Japan and China, have been restricting trade growth after the crisis.

- Increased protectionism: Tariff, non-tariff measures and anti-dumping actions were included in some stimulus packages to favour domestic goods and services. However, evidence suggests that these changes did not play a large role for the trade slow-down (Bems, Johnson and Yi, 2012).

- Trade credit: Some studies found that the lack of credit adversely affected trade volumes during the crisis (Chor and Manova 2012; Bems, Johnson and Yi, 2012), while others found no evidence of this (Levchenko et al., 2010; Behrens et al., 2011). Even though supply of trade credit from Europe was reduced after the crisis, this was partly substituted by credit from other regions.

- Composition of demand: Trade in durable goods fell more than services during the crisis, and since GDP consists mostly of services the decrease in trade was greater than the one in GDP (Bussiere et al., 2011; Bricongne et al., 2012; Eaton et al., 2011; Borchert and Mattoo, 2009). The recovery has seen stronger growth in services than in trade-intensive sectors, contributing to the slowdown in the responsiveness of trade to GDP.

Responsiveness of trade to GDP, 1970-2060

Ratio of world trade in goods and services to world GDP, \%

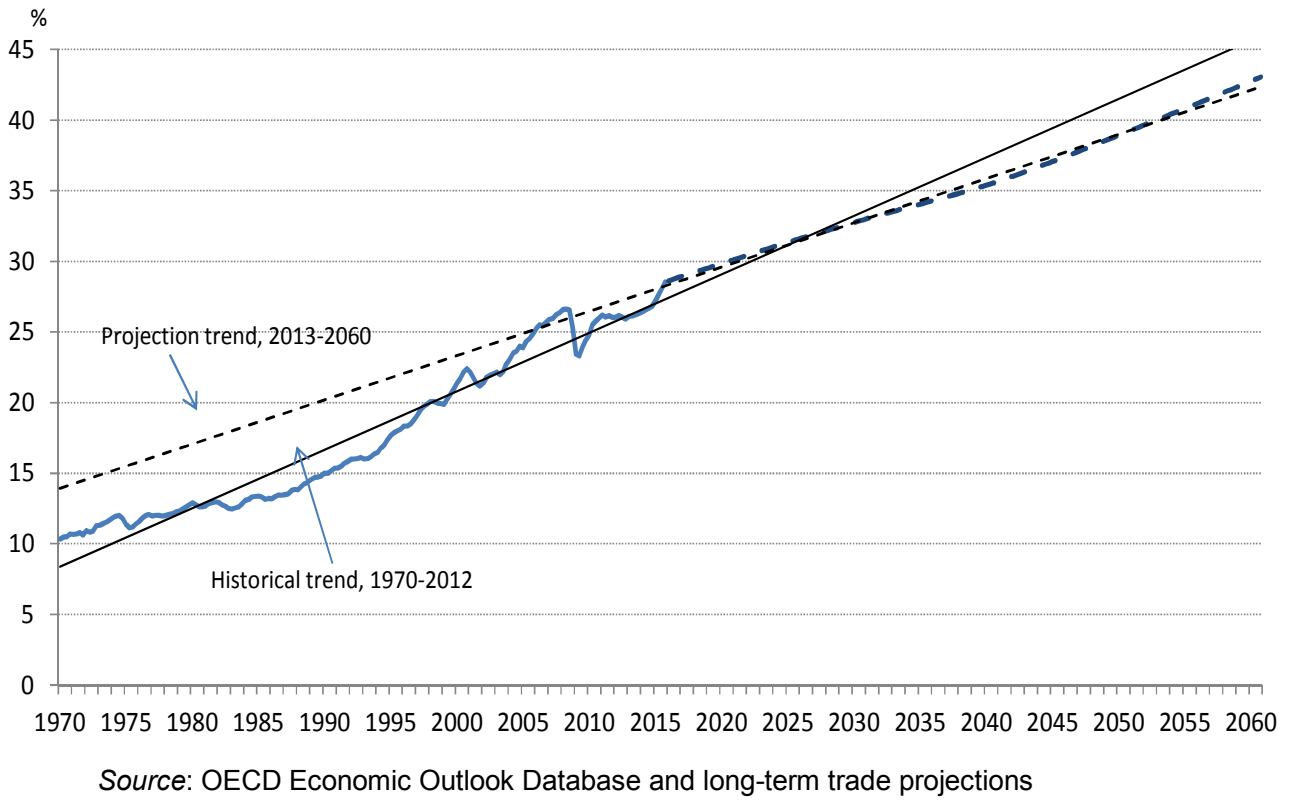


Looking ahead in the scenario presented in Section 4, world trade as a ratio of world GDP is expected to grow at a slower pace over the next 50 years when compared with its pace over 1970-2007 (see Figure above). This implies a lower responsiveness of trade to GDP than in the period 1970-2007. This partly reflects that world growth over the next half century is expected to be less export-led and partly because the intensity of fragmentation of global value chains is hypothesised to slow down as there are likely physical limits on how much a product can be fragmented (Fontagné and Fouré, 2013).

\subsubsection{The changing nature of specialisation}

10. In parallel with increasing trade in final goods, trade in intermediate inputs steadily grew over the past decade, reflecting intensified internationalisation of production. The sourcing of intermediate inputs from foreign countries increased in the supply chains of many industries, thereby reducing the domestic value-added content of exports. Imports of intermediate inputs represent more than $50 \%$ of trade in goods and around $70 \%$ of trade in services (Miroudot et al., 2009) and, in many countries, an increasing share of the intermediate foreign imports ends up in the production of final goods exports. As a consequence, the contribution of domestic factor inputs to exports has decreased in most countries, particularly in smaller (more open) economies as compared with larger or resource rich economies (Figure 3).

Figure 3. Value-added in gross exports varies across countries and industries

Share of domestic value added in gross exports across countries 1995 and 2009, \%

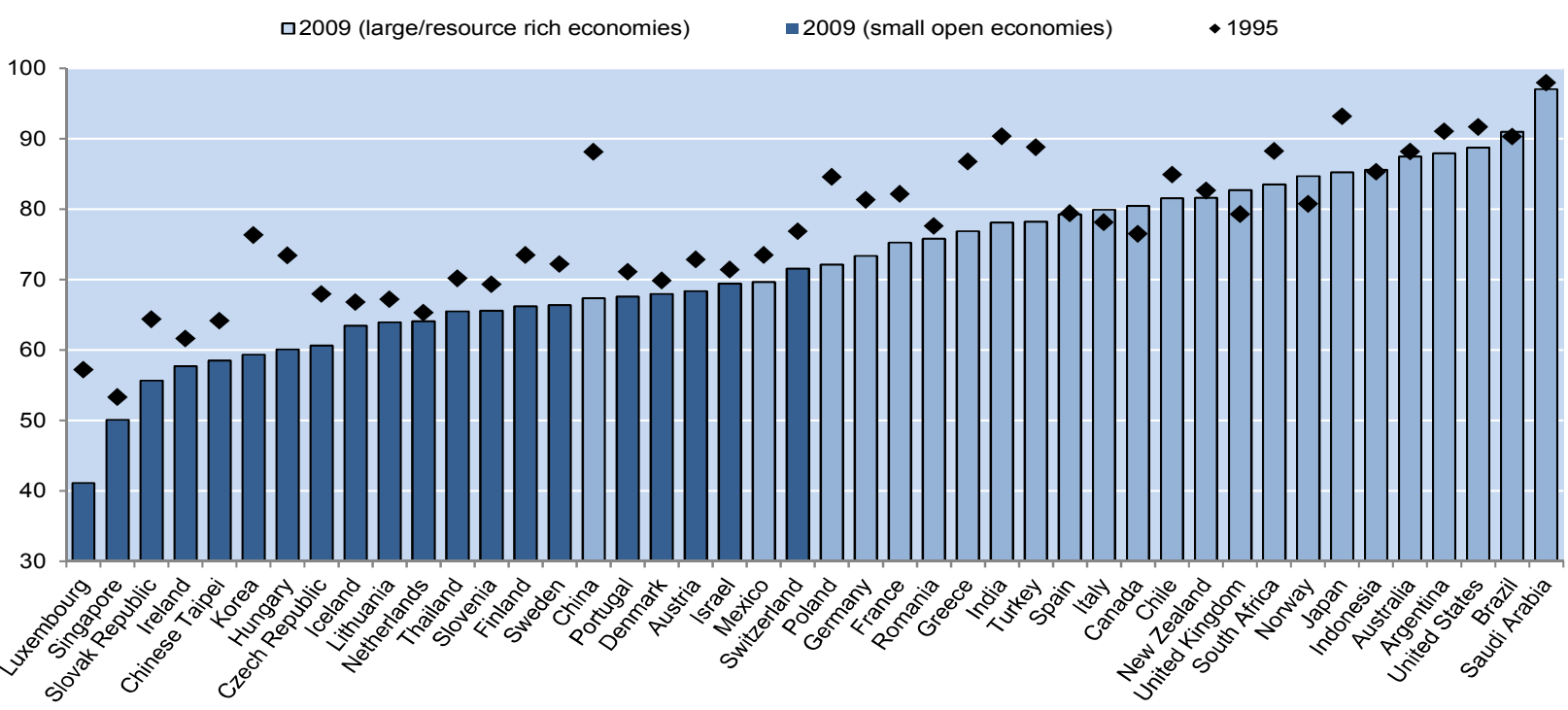

Source: OECD-WTO TiVA Database.

11. Differences in value-added content of exports across countries reflect cross-country differences in the sectoral composition of trade. On average across countries, value creation tends to be higher in services than in manufacturing, reflecting a lower content of foreign intermediate inputs in services than in manufacturing production (Figure 4A). By implication the degree of international fragmentation of manufacturing is greater than in services. In fact, the length of the value chain (measured by the number of production stages), particularly the foreign part of the supply chain, is longer in industries such as communication and electronics, motor vehicles, basic metals and textiles as compared with wholesale and retail trade and other business services (Figure 4B). 
Figure 4. The number of foreign production stages in the supply chain varies across industries

A: Domestic value added in gross export in electronics and business services, 2009

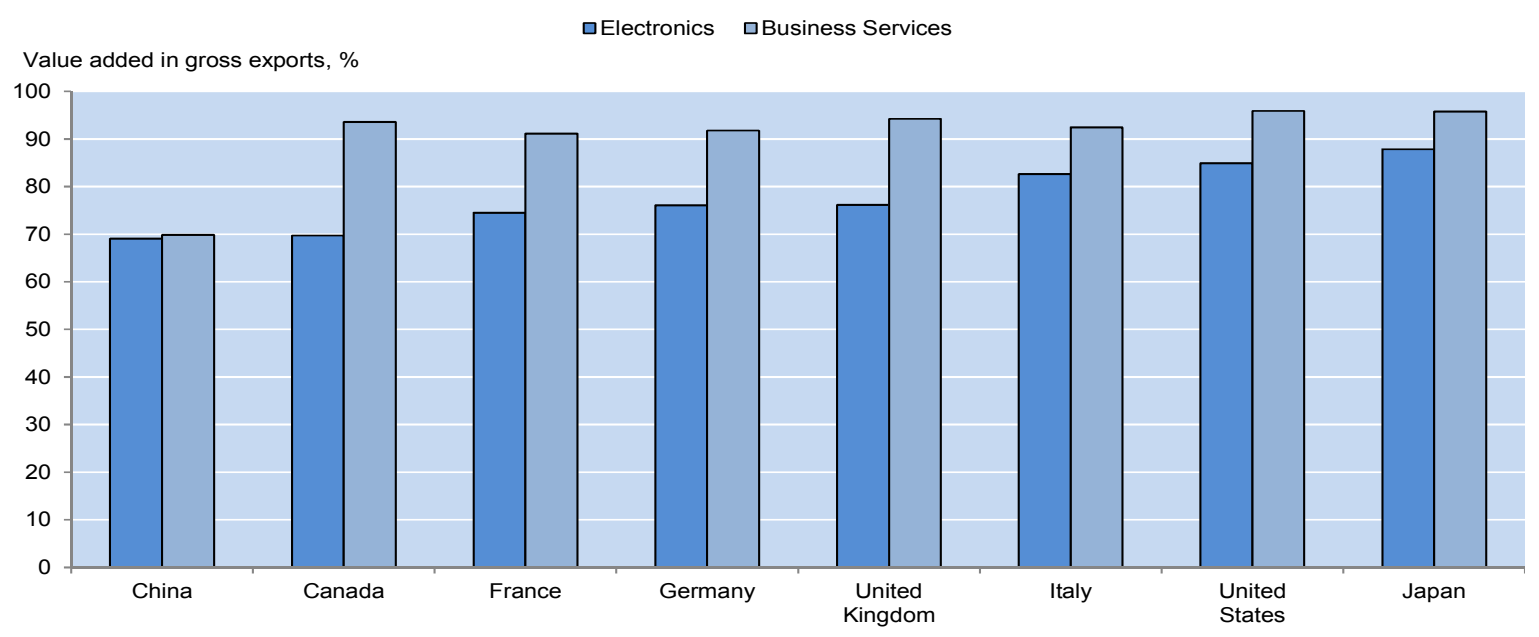

B: The length of the production chain across industries ${ }^{1}$

Average across 58 economies

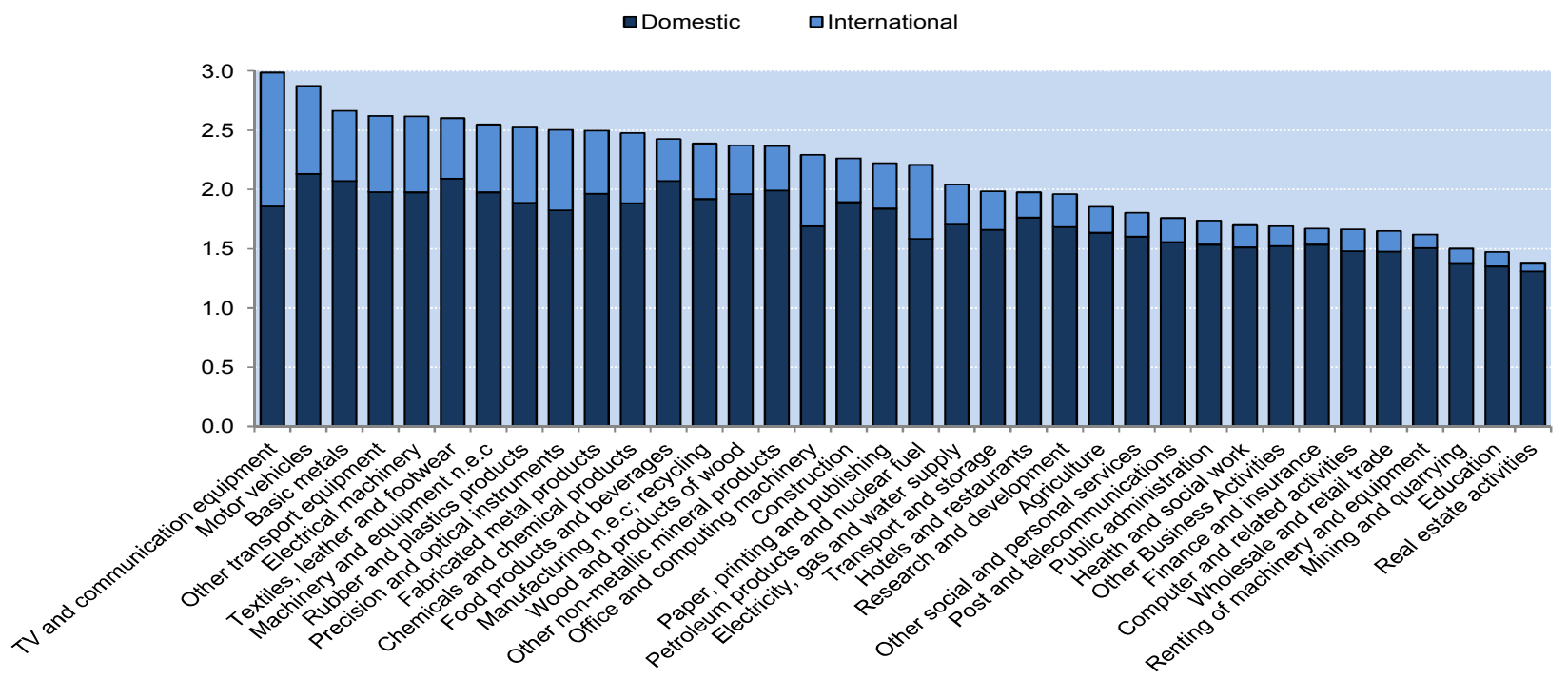

1. The minimum value of the index is 1 when no intermediate inputs are used to produce a final good or service (total production). International denotes the foreign part of the value chain, while domestic denotes the home part of the value chain. The index calculates backward linkages in the production relying on input-output tables that link trade and production internationally (for details on the method see OECD 2012a).

Source: OECD-WTO TiVA Database and OECD (2012a).

12. The increasing importance of global value chains has led to new ways of considering the production process in terms of specialisation in tasks and business functions rather than in specific products (e.g. Grossman and Rossi-Hansberg, 2006; 2008; Baldwin and Robert-Nicoud, 2010; Lanz et al., 2011). Two countries can specialise in the same industry, but they may do it at different stages of the production chain (e.g. upstream or downstream) or in different functions. Thus, the ability of a country to create value-added from trade not only depends on the structure of trade, but increasingly on its 
comparative advantage in tasks within the supply chain that are associated with high value-added. Recent studies suggest that most of the value is created in upstream (innovation, R\&D, design, etc.) and downstream (marketing, branding, logistics, etc.) activities, while pure manufacturing and assembly stages typically add little value (OECD, 2012a). To a certain extent, the shift to reallocate tasks geographically has been facilitated by the development of ICT (Lanz et al., 2011). Therefore, this phenomenon is likely to be encouraged by rising investment in certain types of knowledge-based capital.

13. Unfortunately, cross-country trade data on tasks or functions are not available ít is, therefore, difficult to empirically analyse specialisation in tasks (Box 3). Nonetheless, the implications of the global integration of production networks for skill demand can be analysed on the basis of available data (see below).

\section{Box 3. Specialisation in tasks}

There is little evidence on the determinants of specialisation in tasks and the extent of trade in task, mainly due to lack of cross-country comparable data. Existing studies have found that between $20-30 \%$ of all jobs in major developed economies could potentially be offshored based on how easily the activities performed in a particular occupation can be digitized (Lanz et al., 2011). Based on occupational data for the United States, a recent OECD study created an indirect measure of the tasks content of different occupations by using cluster-analysis to group tasks performed within an occupation. The task content of occupations was then matched with country data on occupations by industry. Based on this measure, the study found evidence that fragmentation of production occurs at the task level. Specifically, the study showed that exposure to trade (measured by import penetration) influences the composition of tasks within an industry, with the effect being stronger for service than goods trade. However, the estimated magnitude of the effect of trade is modest. One possible explanation for these results is that there are economies of scope in bundling tasks and that in a number of industries and occupations firms prefer to assign workers multiple tasks to ensure problem solving and facilitate product innovation, a feature that is hard to capture in empirical analysis (Lanz et al., 2011). More generally, the results need to be interpreted with caution given the indirect measure of task and the limited country coverage.

One insight from the literature on "trade-in-tasks" is that task specialisation is also likely driven by comparative advantage. For instance, regardless of the product, skill-intensive tasks or production stages (e.g. research and innovation, design, marketing, etc.) tend to be localised in skill-intensive countries (see Section 2.2.2).

\subsubsection{Implications for skills}

14. The fragmentation of production in the past decades may have implications for the demand of different types of skills across countries reflecting both the relocation of business activities and trade in tasks. In an integrated global supply chain, firms relocate part of the production process to countries where the availability and costs of the production factors are most favourable to these specific activities. Countries tend to carry out activities within a specific supply chain in which the local value-added content is intensive in their relatively abundant factor or skill, and this has consequences for the distribution of demand for different skills across countries. Here, the changing demand for labour over the past decade (characterised by skill type and sector of employment) was quantified, for a given output level, by means of a structural decomposition, based on the modelling of the input-output structure of the world economy (Los et al., 2014). The decomposition takes into account that the demand for a final good produced in one country does not only induce the need for different skills in the country of completion, but also in various industries in other countries that are providers of intermediate inputs (see Box 4 and Los et al., 2014). 


\section{Box 4. Demand for different skills within a global supply chain}

To assess changes in the demand for jobs characterised by skill type (i.e. low-, medium- and high-skilled) ${ }^{1}$ and sector of employment, as well as the relative importance of the proximate drivers (i.e. technology, trade and consumption) of these changes, a structural decomposition technique was used in 11 key countries and regions, including both advanced and emerging economies, for the period 1995-2008.

The changing structure of employment was analysed based on a modelling of the input-output structure of the world economy using the recently released World Input-Output Table (see Los et al., 2014). Output is the result of the interplay between final demand for final consumer products and capital goods and the intermediate inputs required to produce these final products. The World Input-Output Table is used to estimate the (gross) output level of all industries in each country required to meet final demand (i.e. consumption and investment demand) for a specific product group in a specific country of completion. Once these output levels are determined, information about the labour requirements per unit of output given in the World Input-Output Table can be used to estimate the employment levels by skills associated with the specific final demand level studied. If the employment levels associated with final demand for all products in all countries of completion are estimated in this way, these will exactly sum actual labour inputs in each of the industries in each of the countries.

The demand for different skills in each country depends on i) technological characteristics - that is the quantity of factor inputs to produce one unit of final good in the supply chain, ii) trade - the source of intermediate inputs in the production of the final good, and iii) the composition of consumption. ${ }^{2}$ For instance, technological progress within a supply chain results, all else equal, in lower demand for labour in this supply chain. A change in the source of intermediate inputs in the production of the final good from domestic to foreign suppliers is matched by a reallocation of labour across countries. A change in consumers' composition of consumption towards one specific final good away from another final good induces changes in the demand for labour within these supply chains. If technical progress, geographical fragmentation of production or changing consumer preferences are skill-biased they will in turn have implications for the amount of skilled versus unskilled labour employed in each sector and country.

The decomposition is demand driven meaning that the level and composition of consumption and investment demand drives total output volumes. Hence, the analysis does not take into account the effects of changes in the supply of skills and associated skill premia (general equilibrium effects) on the change in demand for different skills. Nonetheless, this method allows for highlighting compositional effects of demand for different skills across industries, and can be informative about potential tensions between the demand for and supply of different skills across countries.

1. Low-skill refers to completed primary and/or lower-secondary education (ISCED 1 and 2); medium-skill refers to completed uppersecondary and/or non-tertiary education (ISCED 3 and 4); and high-skill refers to completed tertiary education (ISCED 5 and 6 ).

2. Changes in investment demand and its structure are included in the consumption effect.

15. One stark trend that emerges over the period 1995-2008 from this decomposition is a comparatively stronger increase in the demand for high and medium-skilled than for low-skilled workers (Figure 5). The increase in the demand for high-skilled workers was notably strong in some emerging economies, but this partly reflects an increase in demand from an initially low level. By contrast, the demand for low-skilled workers was in general weaker than total labour demand. It declined in several OECD countries, particularly in Japan, France and the United Kingdom, while it remained broadly unchanged or slightly increased in some emerging economies. 
Figure 5. Final demand developments implied that demand for high-skill labour rose across most countries over 1995-2008

\% change in demand for skill types over 1995-2008 relative to the level of the specific skill in 1995

口Low-skill ロMedium-skill घHigh-skill • Total

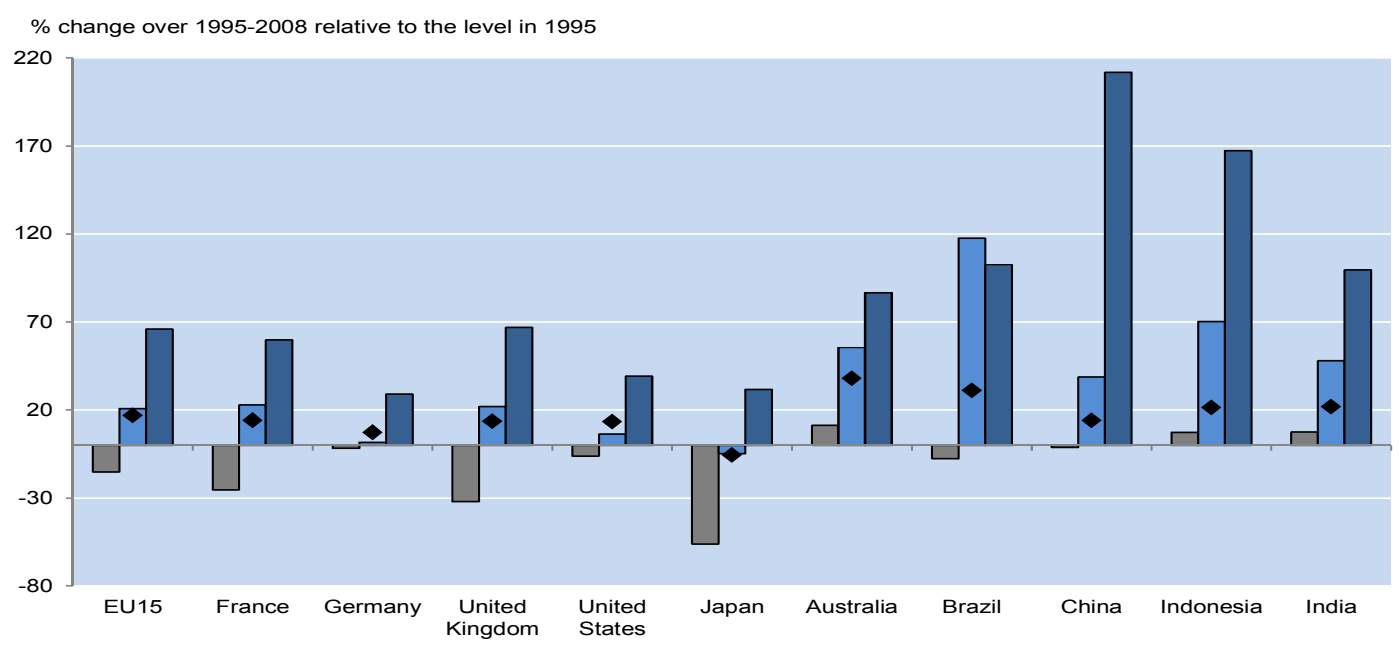

Source: Los et al., 2014.

16. In comparing OECD and emerging economies a contrasting picture emerges also at the sectoral level. While the decline in demand for low-skilled labour over 1995-2008 in OECD economies was to a large extent driven by a reduction in the demand for low-skilled labour within manufacturing or services (other than business services), these sectors contributed to creating low-skill jobs in emerging economies where the decline in low-skilled demand originated from natural resource sectors (Figure 6). The sizeable increase in demand for high-skilled labour was mainly driven by an increase in demand for high-skill workers in services, albeit in some countries (e.g. China, India, and France) manufacturing also added to high-skill demand.

Figure 6. Contribution of broad sectors to the change in demand for skills, $1995-2008, \%$

Contribution of broad sectors to the change in demand for different skills
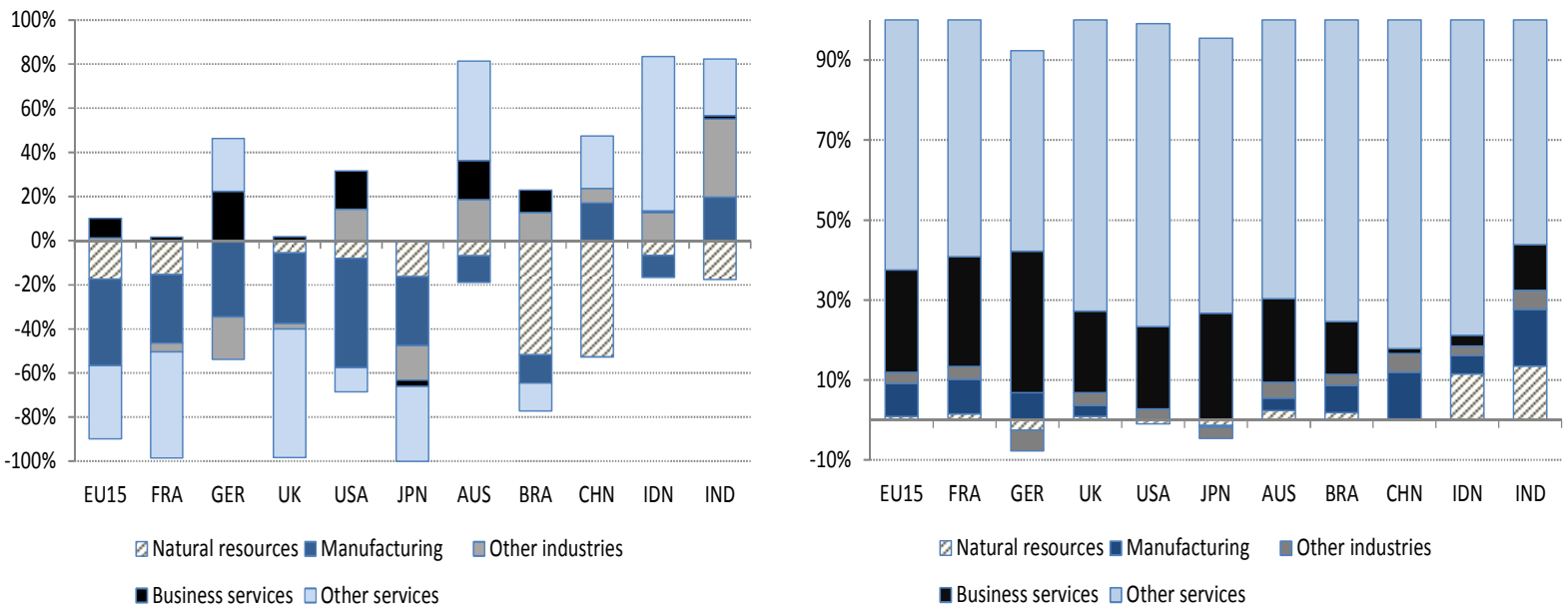

Source: Los et al. 2014. 


\subsubsection{Technology, trade and changing consumer preferences influence the demand for skills}

17. One explanation for the declining demand of lower skills in advanced economies focuses on the integration into the world market of less-developed economies, which are relatively abundant in lowskilled workers, and the accompanying outsourcing of production from richer to lower-income countries (e.g. Feenstra and Hanson, 1996). However, these trade models cannot explain the generalised increase in the demand for higher skills (and wage differentials) across both advanced and emerging economies (Feenstra and Hanson, 1996; Van Reenen, 2011; Kierzenkowski and Koske, 2012). Instead, the increasing demand for high-skilled labour is often attributed to the introduction of new technologies and a shift in the production technology that favours skilled over unskilled labour by increasing its relative productivity and, therefore, its relative demand (e.g. Katz and Murphy, 1992; Autor et al., 1998; Greenwood, 1999; Acemoglu and Autor, 2011). Skill-bias technological change and trade are related since trade may induce skill-biased technological change, while technological change may enable trade. This makes it difficult to fully disentangle their effects on demand for skills (Autor et al., 2003; Acemoglu, 2003). Finally, changing consumer preferences and consumption patterns can shift the demand for different types of goods and affect demand for skills across countries (Los et al., 2014).

18. Results from the structural decomposition of world output bring the following insights on the relative importance of these three forces:

- Consumption, including changes in its structure increased demand for all skill categories (Figure 7). While consumption tends to have increased the demand for high-to-medium skilled labour relatively more than that for low-skilled in OECD economies, the opposite happened in emerging economies. The extent to which this trend will continue is uncertain, given the likely shifts in consumption towards services in emerging economies.

- Technological change played a key role in explaining the fall in demand for low and mediumskilled workers (Figure 8). The types of jobs lost differ across advanced countries. In the United States about $85 \%$ of the jobs lost due to technology were medium-skilled, while in European countries (EU-15) most of the lost jobs were instead low-skilled. By contrast technological change resulted in an increased demand for high-skilled workers in OECD economies.

- Trade effects were comparatively smaller than those in consumption and technology, and had opposite effects on skill demand in OECD and emerging economies. As a result of trade, the latter experienced increased demand for low-to medium-skilled jobs, and the former experienced a fall in demand for these skills. Sectors that are more open to trade and integrated in long supply chains tend to see comparatively greater reallocation effects. Electronics industries in European countries lost around 2300000 low to medium-skilled jobs over 1995-2008 and out of those nearly $50 \%$ were lost due to trade related changes, while in market services only $20 \%$ of low to medium skilled job losses were due to trade (Figure 8). Similarly, China experienced relatively larger trade-induced increases in demand for low-to medium skilled workers in the electronics sector than in market services. ${ }^{4}$

4. These findings are consistent with studies highlighting that offshoring triggers a specialisation in activities in which routine tasks within manufacturing industries are reallocated from higher-income (high wage) to lower-income (low-wage labour intensive) countries (e.g. Baldwin 2006). 
Figure 7. Change in number of jobs due to technology, trade and consumption, 1995-2008 (thousands) ${ }^{1}$

A: OECD countries

口Technology

-Trade aConsumption - Total

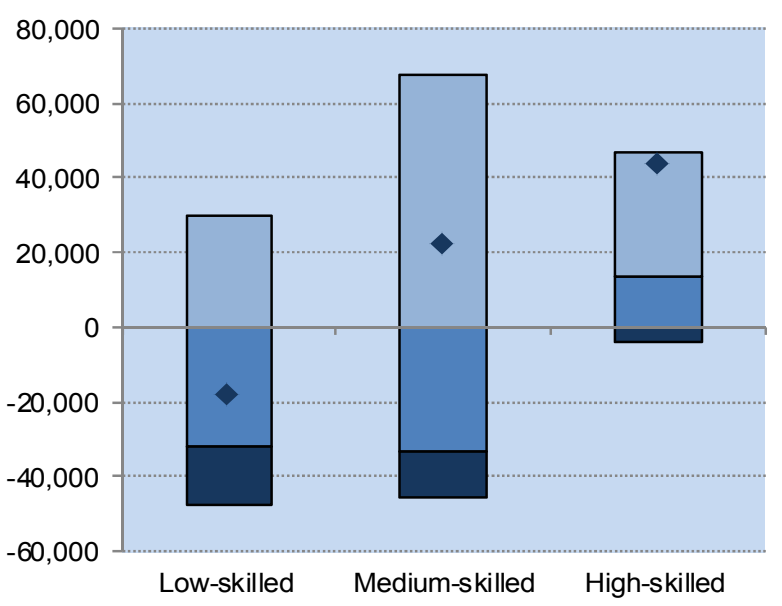

B: Emerging economies

口Technology $\mathbf{a}$ Trade $\square$ Consumption • Total

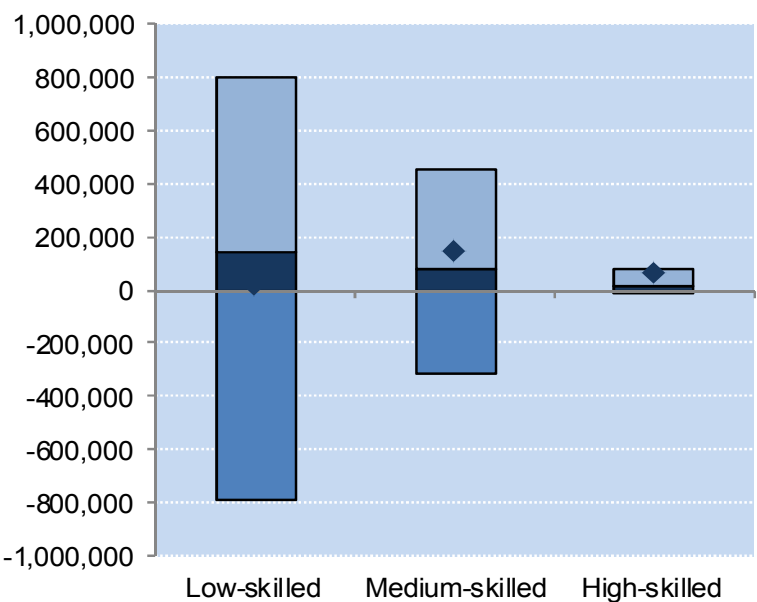

1. Advanced economies include EU-15, the United Kingdom, The United States, Japan and Australia while emerging economies include India, Indonesia, Brazil and China.

Source: Los et al. 2014.

Figure 8. Proximate determinants of the change in number of jobs by skills in electronics and market services

A. Electronics, 1995-2008 (thousands)

EU-15

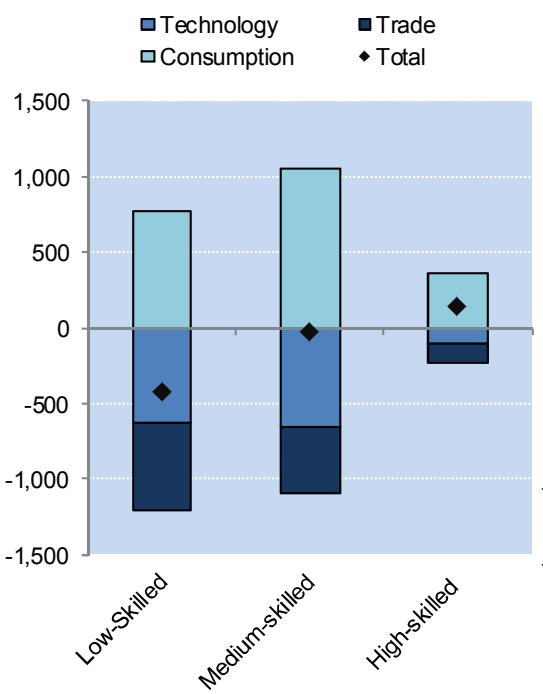

The United States

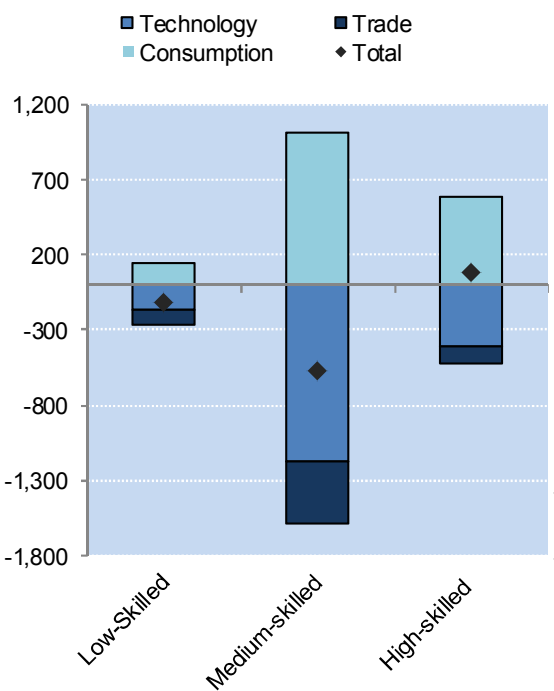

China

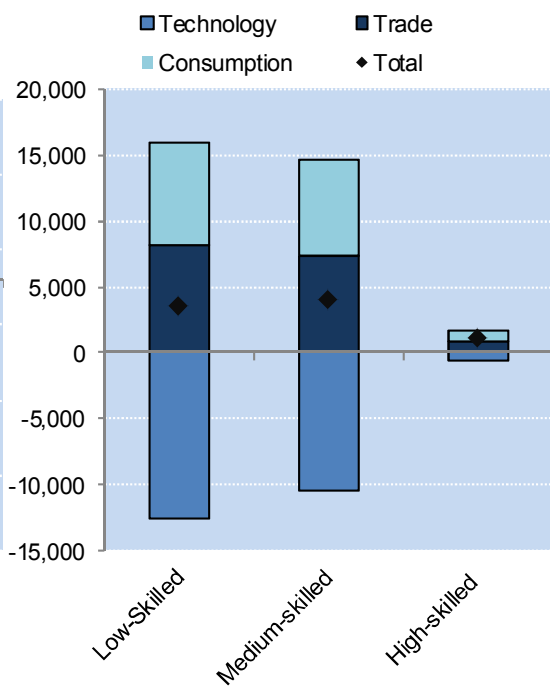


B. Market services, 1995-2008 (thousands)
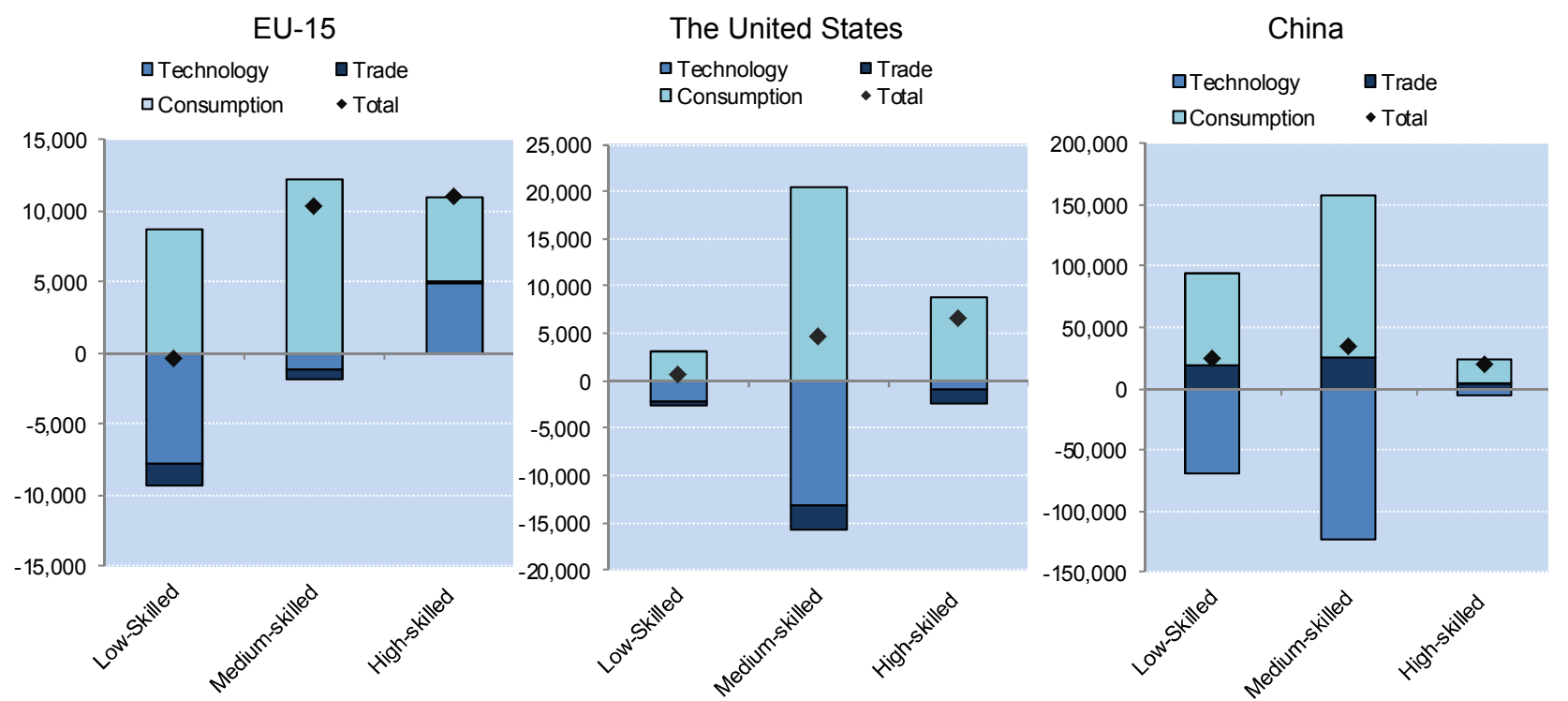

Source: Los et al. 2014.

\subsubsection{Implications for wage inequality}

19. A shift in the demand of labour towards higher skills can contribute to raise wage inequality, especially when this is not matched by a sufficiently rapid increase in the supply of skilled workers. In parallel with the tendency for labour demand to shift towards higher skills, some OECD countries in fact saw a rise in labour income inequality between the mid-1990s and the mid-2000s measured as the ratio of the $90^{\text {th }}$ to $10^{\text {th }}$ percentile of labour earnings (Koske et al., 2012). An increase in inequality also occurred in some non-OECD emerging economies measured as the ratio of hourly labour compensation of high-skilled relative to low-skilled workers. By contrast, in several countries inequality remained broadly unchanged or it even declined, consistent with earlier studies.

20. The findings from the structural decomposition suggest that skill-biased technological change is one key factor behind the steady demand for better-educated workers, in line with existing empirical studies (e.g. Katz and Murphy 1992; Autor et al., 1998). Other studies also highlight the structural transformation from manufacturing to services as an important force behind the increase in the wage premium in the United States (e.g. Blum 2008; Mollick 2012). Drawing on this literature, OECD evidence shows that specialisation contributes to explain cross-country differences in wage gaps between skilled and unskilled workers, after controlling for other influences notably the supply of skilled workers and a proxy for technological change (see Box 5; Johansson and Olaberría, 2014). Parallel evidence also shows that skill-biased technological change is a major determinant of the widening of the ratio between the $90^{\text {th }}$ and $10^{\text {th }}$ percentiles of labour earnings (Braconier et al., 2014). Within countries, specialisation in high-skilled industries is associated with a widening of the wage gap between skilled and unskilled labour, while specialisation in low-skilled industries is associated with a narrowing of the wage gap. Consistent with existing evidence (e.g. OECD, 2011b), an increase in the supply of skilled workers is found to mitigate the wage gap between skilled and unskilled labour as well as between the $90^{\text {th }}$ and $10^{\text {th }}$ percentiles of labour earnings (Braconier et al., 2014).

21. As illustrated in Figure 9 the estimates suggest, for example, that the increase in the value-added share of the four industries most intensive in high-skilled labour observed in China from 1995 to 2009 widened the wage gap between skilled and unskilled labour by $4 \%$. At the same time, the decrease in the 
value-added share of the four industries most intensive in low-skilled labour further widened the wage gap by $30 \%$. The relative increase in the supply of skilled labour over 1995-2009 was not sufficient to offset the widening of the wage gap between skilled and unskilled labour resulting from the rise in demand for skilled labour.

Figure 9. Impact of specialisation and supply of skills on wage gaps between skilled and unskilled labour, 1995-2009

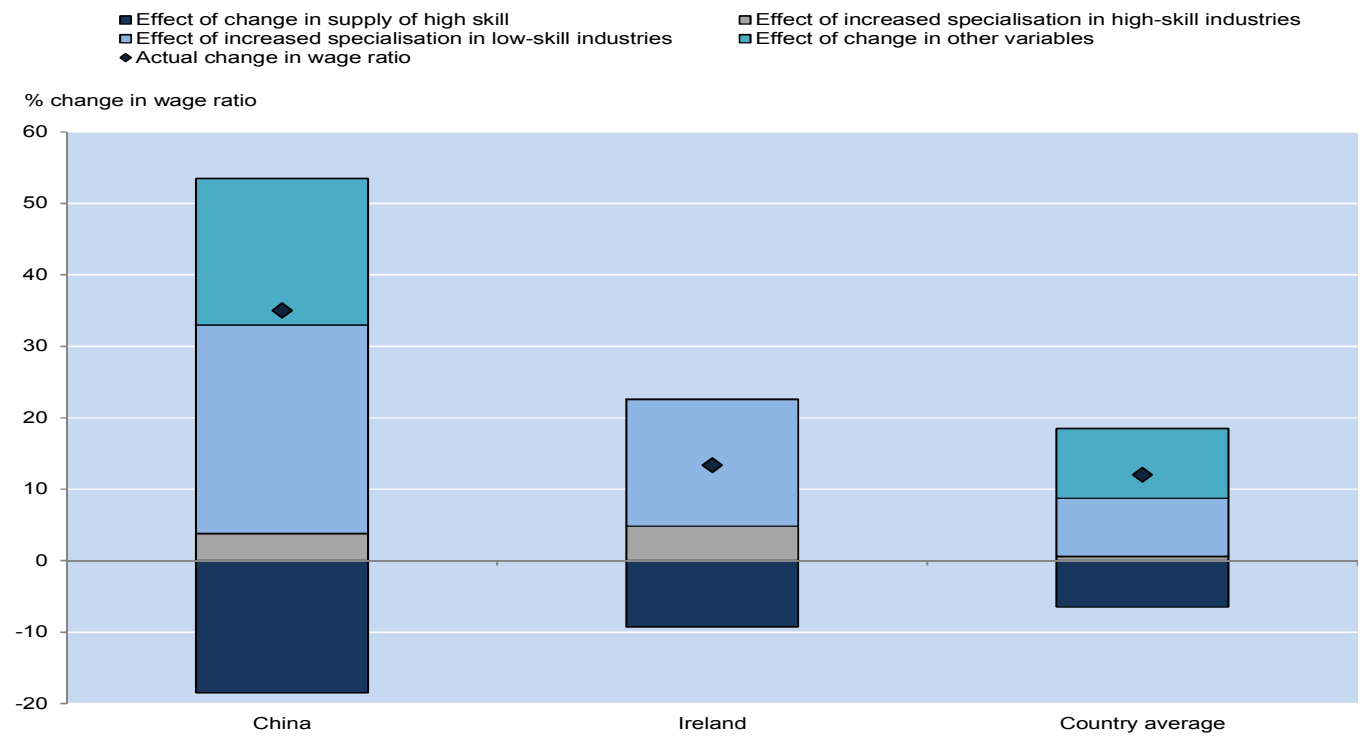

1. The bar shows the decomposition of the contribution to the change in the wage gap between skilled and unskilled labour over 1995-2009 of changes in the supply of high-skill labour, the demand for high-skill workers, the demand for low-skill workers and other variables. The triangle shows the actual change in the wage gap between skilled and unskilled labour over the estimation period 1995-2009. High-skilled (low-skilled) specialisation is measured as the sum of value added of the four industries that are the most intensive in the use of high-skilled (low-skilled) labour as percent of total value added (see Johansson and Olaberría, 2014 for details).

Source: OECD estimates.

\section{Box 5. Empirical approach used to study wage gaps between skilled and unskilled workers}

The econometric specification examining the distributional consequences of skill-biased-specialisation uses annual cross-country, time-series data on value added and wages by skill level from the World Input-Output Database (WIOD) covering 35 OECD and non-OECD countries over 1995 to 2009. The empirical analysis exploits the variation over time to examine how changes in wage gaps between skilled and unskilled workers are related to changes in specialisation in industries that demand more high-skilled workers. The following fixed-effects specification is used:

$$
\log \left(\text { Wage Gap }_{i t}\right)=\alpha+\beta S B S_{i t}+\rho \text { StockHK } K_{i t}+\varphi \operatorname{Trade}_{i t}+\gamma \operatorname{Tech}_{i t}+\delta C V_{i t}+\theta_{i}+\theta_{t}+\varepsilon_{i t}
$$

where Wage Gap is measured by the ratio of hourly compensation of high-skilled workers to low-skilled workers. The explanatory variables include: SBS is an index of skill-biased specialisation measured as the weighted sum of industry value-added where the weight is the share of high-skilled labour in total labour in that industry; StockHK is the stock of high skills measured as the share of the population with tertiary education; Trade is a measure of trade openness; Tech is an indicator of technological progress measured by total factor productivity; $C V$ is a set of control variables including the share of female employment, the growth of GDP (to capture cyclical fluctuations in aggregate demand) and institutional variables identified as relevant for relative wage outcomes in earlier OECD studies such as employment protection (see OECD 2011b). Equation 1 is estimated by a fixed-effects model with country-specific effects and year-specific effects to capture common global shocks and business cycle effects. The dependent variable and most explanatory variables are logarithm-transformed (see Appendix 2). 


\section{Policies, trade and specialisation}

22. Policies and institutions can influence trade and specialisation. The main justification behind policy attempts to affect specialisation by supporting specific industries is the presence of externalities, scale effects or market failures preventing an efficient allocation of resources such as labour and capital (e.g. Harrison and Rodriguez-Clare, 2009). A key caveat is that any policy involving "picking winners" is difficult to implement. Given this difficulty, industrial policies often cause waste (e.g. some activities would have been undertaken even in the absence of policies), lock in inefficient activities and encourage rent-seeking. This section focuses on a subset of policies that the existing literature has identified as important drivers of bilateral trade including trade policies (e.g. tariffs), financial development, product and labour market regulations (Nunn and Trefler, 2013; Nicoletti et al., 2003). As a background to the long-run scenarios drawn in Section 4, it discusses and explores empirically the impact of these policies on trade and specialisation controlling for other influences including factor endowments and gravity forces discussed in Section 2 (see Box 6). The evidence discussed in this section is based on measures of gross exports and on value added share of industries. ${ }^{5}$

\section{Box 6. Empirical approaches for identifying determinants of specialisation}

The empirical research underlying the findings in this paper uses both country- and industry-level data to explore the channels through which factor endowments and policies affect trade and specialisation. Two sets of analyses are undertaken. The first study, based on gross exports and imports, exploits trade data covering 20 manufacturing industries and 54 high- and low-income countries (see Johansson et al., 2014 for details). The second analysis focuses on the industry value-added (as a share of GDP) using data from the World Input-Output Database (WIOD) covering 40 high- and low-income countries and 27 industries, including manufactures and services. Since data come from different sources, the sample of countries differs across the analyses (Johansson and Olaberria 2014 for details). However, both analyses include OECD and emerging economies.

The empirical analysis uses yearly data over the period 1995-2008. It ends in 2008 to avoid the great disruption to trade created by the crisis, and starts in 1995 because, although economic globalisation had been building up over many decades before 1995, the pattern of globalisation has changed in important ways since the mid-1990s. As argued by Haskel et al., (2012), at least three significant changes affected trade patterns since the mid-990s. First, policy barriers to trade were reduced significantly, at the multilateral level, after the 1994 Uruguay Round; many regional trade agreements were created (e.g. NAFTA, Mercosur) and, in 2001, China joined the World Trade Organization (WTO). Second, natural barriers to trade significantly declined with the creation of the internet, driving the cost of invoice and data to almost zero. Third, the growth of GDP and demand of emerging countries accelerated in the mid-1990s, particularly in China, India, Russia and Brazil.

To explore the links between policies and aggregate trade the empirical approach uses the standard gravity equation to which factor endowments and policies are added:

$$
\text { GExp }_{i j t}=\alpha+\gamma \text { Gravity }_{i j t}+a_{1} \text { End }_{i t}+a_{2} \text { Pol }_{i t}+a_{3} \text { End }_{j t}+a_{4} \text { Pol }_{j t}+\theta_{i}+\theta_{j}+\theta_{t}+\varepsilon_{i j t}
$$

where GExp represents gross exports; $i$ denotes exporter, $\mathrm{j}$ importer and $t$ time. Gravity is a combination of variables that affect the cost of trade including common border, common language, distance, GDP of exporter and importer and the presence of a regional trade agreement. End is a set of factor endowments at the country-level such as capital per worker, energy and stock of human capital. Finally, the regression includes fixed effects for exporter $\Theta_{\mathrm{i}}$, importer $\Theta_{\mathrm{j}}$ and time $\Theta_{\mathrm{t}}$. The exporter and importer fixed effects capture unobserved country-specific characteristics that are not correlated with industry characteristics (e.g. cultural factors). The time fixed effects captures unobserved time-variant effects that are common to all countries and industries, such as business cycles or waves of deregulation.

5. The increasing importance of foreign intermediate inputs in trade implies that measures of specialisation based on gross exports do not necessarily reflect the underlying comparative advantage of a country (Koopman et al., 2010). One way to better capture this advantage is to rely on measures of the value-added content of exports. But, empirical analysis suggests that the determinants of gross exports and exports in value added are broadly the same qualitatively and quantitatively (see Appendix 1). 
To explore the links between policies and the composition of trade, the empirical approach follows a methodology that is increasingly being used in the literature (e.g. Chor, 2010, Kowalski, 2011 and Nunn and Trefler, 2013). The main assumption is that industries differ in the factors and institutional conditions needed for production, and countries differ in their ability to provide for these industry-specific requirements. Therefore, the country variables - factor endowments and policies - are interacted with industry characteristics (e.g. share of capital in production, dependence on external finance, input variety, etc.). For instance, the country level measure of stock of human capital is interacted with an index of the intensity with which each industry employs high-skill workers. The regression also includes endowments and policies of the importer to analyse potential spillover effects among trading partners, and the endowments and policies by themselves - without the interaction - to analyse potential common effects across industries. Specifically, for the analysis on the determinants of gross exports the regression is:

$$
\text { GExp }_{i j s t}=\alpha+\gamma \text { Gravity }_{i j t}+\beta_{1} \text { End }_{i t} * \text { Int }_{s}+\beta_{2} \text { Pol }_{i t} * \text { Sensit }_{s}+\beta_{3} \text { End }_{j t} * \text { Int }_{s}+\beta_{4} \text { Pol }_{j t} * \text { Sensit }_{s}+\theta_{i}+\theta_{j}+\theta_{s}+\theta_{t}+\varepsilon_{i j s t}
$$

Equation 2 differs from equation 1 in that GExp now represents gross exports by industry indexed by $s$ and the inclusion of sector-specific endowments which are created by the interaction between End at the country-level and the intensity $(I n t)$ with which the industry employs the endowment. Similarly, Pol denotes the policy and institutional variables including financial development, institutional quality, labour and product market regulations and taxes. The sector-specific policies are created by the interaction between $\mathrm{Pol}$ at the country-level and the sensitivity (Sensit) the industry has with respect to the policy, with sensitivity measured in different ways depending on the policy (e.g. the need of external finance, the variety of intermediate inputs, labour intensity, profitability etc.) Finally, this regression also includes fixed effects by industry $\Theta_{\mathrm{s}}$ which captures unobserved industry characteristics such as how tradeable the goods are or changes in relative prices between industries that are common in all countries.

The empirical strategy is similar for the analysis of the determinants of production specialisation measured by industry value-added as a share of GDP (VAShare). The regression in this case is:

$$
\text { VAShare }_{i s t}=\alpha+\beta_{1} \text { End }_{i t} * \text { Int }_{s}+\beta_{2} \text { Pol }_{i t} * \text { Sensit }_{s}+\theta_{i}+\theta_{s}+\theta_{t}+\varepsilon_{i s t}
$$

\subsection{Unbundling of production can magnify the adverse effect of tariffs}

23. Frequent justifications for tariffs are that they can allow domestic industries to grow by enabling the development of economies of scale, which promotes efficiency (e.g. infant industry argument); they can prevent "dumping" in the home country of foreign goods at a price below cost; and, in some countries, particularly emerging economies, they constitute an important source of government revenue. However, tariffs generally have an adverse effect on trade and aggregate welfare since they distort production and raise consumer prices. As a revenue source, other taxes may be more efficient than tariffs. For instance, since tariffs influence both production and consumption decisions they create larger inefficiencies than consumption taxes (Emran and Stiglitz, 2005). Tariffs can also influence trade patterns and the industrial structure by raising the cost of intermediate inputs. ${ }^{6}$ Apart from imposing costs on firms, intermediate input tariffs can limit the access to more varieties and to high quality intermediate inputs and, thereby further reduce competitiveness in international markets (e.g. Grossman and Helpman, 1991; Amiti and Konings, 2007).

24. Intermediate input tariffs can have adverse effects on both industry structure and trade (Johansson et al., 2014). For instance, OECD estimates suggest that if tariffs on electronics (a sector that relies heavily on imported inputs from the same industry) were to be reduced in a country where such tariffs are high (e.g. Brazil) to the median level in the sample of countries included in the analysis, electronic exports could increase by $26 \%$ (Figure 10). Furthermore, intermediate input tariffs do not only affect exports in the same industry, they also have a sizeable negative effect on exports of downstream industries. For instance, if a country with high tariffs on textiles (e.g. South Africa) were to reduce them to

6. Tariff rebates on intermediate inputs or refunds when the goods are exported exist in some countries. However, often these schemes entail administrative procedures and documentation that in some cases can be more costly than paying the tariff (OECD, 2010a). 
the median level in the sample of countries included in the analysis, exports of clothing from this country, whose inputs embed more than $40 \%$ of textile products, could increase by more than $30 \%{ }^{7}$

Figure 10. Cuts in tariffs on key intermediate inputs boost trade in the same and in downstream industries ${ }^{1}$ $\%$ change in gross exports of tariff cut

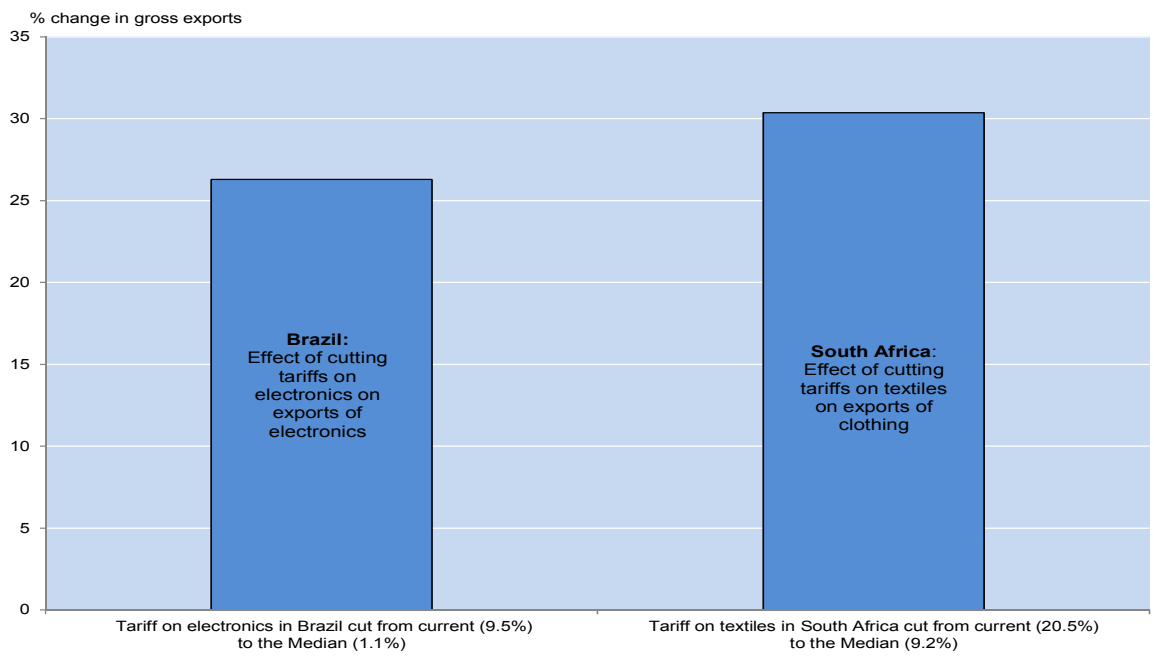

1. The left bar shows how much Brazilian electronics exports could increase if Brazil (the country with highest tariffs on electronics in 2007) would decrease its tariffs on electronics to the median in the distribution of the countries included in the analysis. The right bar shows how much South African clothing exports could increase if tariffs on textiles were cut to the median among the countries included in the analysis (see Johansson et al. 2014 for details).

Source: OECD estimates.

25. The adverse effect of input tariffs on trade has grown over time. This may reflect the increasing importance of global value chains, with the unbundling of production magnifying the impact of tariffs and generating cross-country spillovers that go beyond the effect of tariffs on bilateral trade with direct trading partners (Koopman et al., 2010; OECD, 2012b). In an integrated value chain, imposing tariffs at one stage on a foreign product affects the whole chain of suppliers through backward and forward linkages. Koopman et al., (2010) calculate so-called "tariff-magnification ratios" for manufacturing products and show that taking into account tariffs along all stages of the supply chain raises significantly the effective tariff protection. ${ }^{8}$

\subsection{Sound public institutions can enhance trade in industries with long value chains}

26. Sound public institutions that facilitate contract enforcement, adequately secure property rights, and ensure an impartial judiciary, allow trading partners to overcome trade frictions (e.g. Anderson and Van Wincoop, 2004; Acemoglu et al., 2007; Nunn and Trefler, 2013). Thus, the quality of institutions can enhance aggregate growth by increasing trade. It allows industries that depend more on a large set of intermediate inputs (e.g. through long value chains) or on non-contractible inputs (e.g. intangibles assets) to grow faster (e.g. Nunn and Trefler, 2013; Levchenko 2007). For instance, evidence shows that regulatory quality (measured by the World Bank's index on regulatory quality) can boost trade of

7. These effects may appear large, but it should be noted that the tariff reductions in the example are sizeable, around 10 percentage points.

8. The study found that in 2004 the effective tariff rate was $17 \%$ higher than the nominal rate in the United States, $46 \%$ higher in Korea and as much as $116 \%$ and $171 \%$ higher in China and Mexico, respectively, due to multiple border crossing in trade. 
industries that rely on a large variety of inputs (Johansson et al., 2014). Estimates suggest that improving the regulatory quality from the median to the level of countries with relatively good institutions (i.e. at the $75^{\text {th }}$ percentile of the distribution of countries included in the analysis) could increase exports in industries that rely on a wide variety of inputs (e.g. basic metals or electronics) by around 5\% (Figure 11A). The effect on total exports is, however, modest. Furthermore, the same change in regulatory quality increases total imports on average by $3 \%$, reflecting that the ability to source intermediate inputs and to integrate into global production chains are facilitated by high-quality institutions.

\section{Figure 11. Policies and institutions influence trade and specialisation}

A. Effect of a change in the quality of institutions on total exports and on exports of goods that are strongly dependent on sound institutions ${ }^{1,2}$

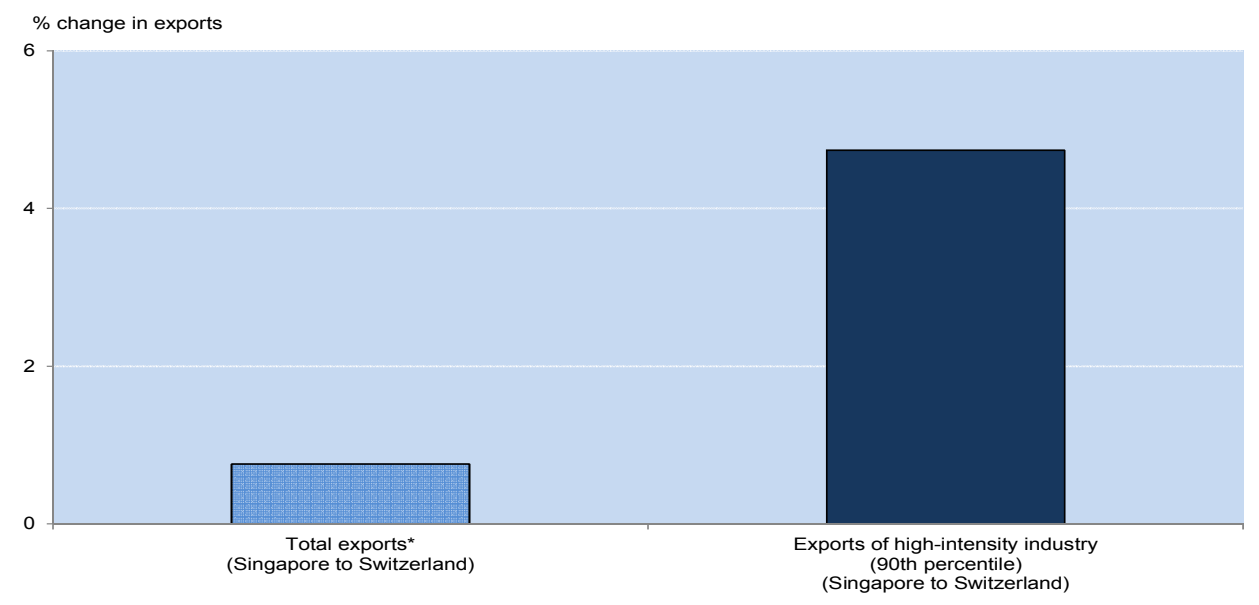

${ }^{*}$ Effect not statistical significant

B. Effect of a change in financial development on total exports and on exports of goods that are strongly dependent on finance $^{1}$

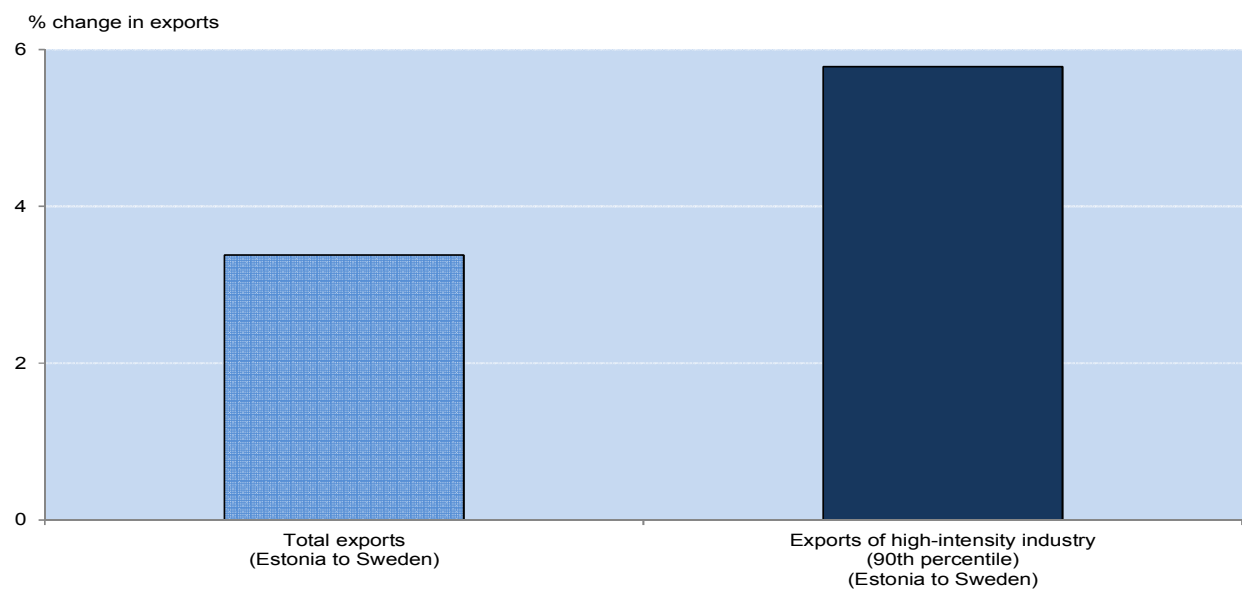

1. The right bars show the percentage change in the value of gross exports of the industry at the $90^{\text {th }}$ percentile level of sensitivity on the policy, when comparing the country at the median with the country at the $75^{\text {th }}$ percentile of the country-level distribution of the policy.

2. Financial development is measured by domestic credit to the private sector as a share of GDP from the World Bank Development Indicators and quality of institutions is measured by the indicator of regulatory quality sourced from the World Bank Governance Indicators. The intensities capture the sensitivity of different industries to the relevant policy and are based on different sources (Johansson et al. 2014 for details).

Source: OECD estimates. 


\subsection{Financial development can alleviate cash constraints and facilitate trade and growth}

27. Well-functioning financial systems can promote long-term growth by reducing information and transactions costs, providing appropriate incentives for business governance and easing external financing constraints that impede firm growth and the efficient allocation of resources (e.g. Levine, 2005; Andrews and Criscuolo, 2013). More developed financial systems can also increase the volume of trade (Chor and Manova, 2012), which in turn can raise growth by, for instance, facilitating access to technology. Firms' ability to export and imports depends on trade costs, including financial costs. By lowering the cost of trade, well-functioning financial system can increase the number of potential trading partners and the volume of trade. Financial development can also affect specialisation by promoting faster growth in industries that depend more on external financing (e.g. Rajan and Zingales, 1998; Beck, 2002). The need for external finance tends to be greater in the start-up phase of firms and particularly in industries with large initial investment and continued investment requirements combined with long cash harvest time (e.g. electronics, pharmaceuticals) (Rajan and Zingales, 1998). These industries also tend to be comparatively more innovative than other industries, adding to aggregate growth.

28. Estimates suggest that financial development (measured by the ratio of private credit to GDP) enhances trade, particularly in goods whose production is highly dependent on external finance (Johansson et al., 2014). For instance, if financial development were to increase from that of the median country to the level of the country at $75^{\text {th }}$ percentile among the countries included in the analysis (e.g. from Estonia to Sweden), this would increase total exports by 3\% (Figure 11B). However, this change could increase exports of industries that are highly dependent on external finance (e.g. electronics) by $6 \%$ (Figure 11B). The same increase in financial development could increase imports by as much as $4 \%$. Thus, wellfunctioning financial markets can create spillovers to trading partners.

\subsection{Market rigidities hinder specialisation}

29. The capacity of countries to reap the full benefits of trade integration by adapting their industrial structure depends on their ability to reallocate resources across sectors and firms. Several studies have found that well-functioning financial, labour and product markets improve the ability to continuously reallocate resources towards their effective use (e.g. Levine, 1997; Andrews and Cingano, 2012; Barone and Cingano, 2011; Arnold et al., 2008), with positive implications for growth.

30. Well-developed financial institutions can enhance the allocation of resources to their most productive use (Levine 1997), and they can also promote faster growth in industries more dependent on external funds. In fact, OECD estimates suggest that financial development would increase the value-added share of industries highly dependent on external finance (Johansson and Olaberría, 2014). For instance, if financial development were to increase from that of the median country to the level of the country at the top quartile (e.g. from Estonia to Sweden), the value-added share of industries highly dependent of external finance would increase by 0.2 percentage points (Figure 12). This change may seem small, but considering that the value added share of GDP, for example, of the electronics industry (which is highly dependent on external financing) is on average $1.5 \%$ across countries, the change is sizeable.

31. Burdensome product market regulation hampers the ability of firms to adjust to rapid change by hindering growth of the most efficient firms and preventing the exit of inefficient ones (Andrews and Cingano, 2012). For example, in industries (e.g. pharmaceuticals, electronics, hotels and restaurants) with naturally higher reallocation needs (measured by firm turnover) stringent regulations can reduce the efficiency of these industries disproportionately. Estimates suggest that a reduction in the stringency of product market regulations from the top quartile (e.g. Russia) to the median (e.g. France) would increase the value-added share of industries with a structurally high turnover by 0.1 percentage points (Figure 12; Johansson and Olaberría, 2014). If firms and industries that require higher firm turnover are also more 
dynamic and fast-growing, flexible regulations can shift resources to these sectors away from more stagnant ones, with positive growth effects (Andrews and Criscuolo, 2013). However, it is important to recognise that flexible regulations can also promote sectors with high turnover that lack dynamism and have low productivity growth (e.g. hotels and restaurants).

32. Employment protection legislation - through its impact on hiring and firing costs - can also affect specialisation by reducing the ease of reallocating workers across firms and sectors, with adverse productivity effects. However, employment regulations, by reducing (involuntary) labour turnover, can also enhance an individual's incentive to invest in firm-specific human and social capital (e.g. Dess and Shaw, 2001) and thereby raise a firm's productivity growth. Recent studies emphasise that, ceteris paribus, industries that naturally require greater job reallocation grow faster (and account for a greater share of GDP) in countries with easier labour market regulations (Cunat and Melitz, 2012), a prediction that is supported by available empirical evidence (e.g. Chor, 2010; Kowalski, 2011). New estimates suggest that easing labour market regulations (measured as OECD's indicator of employment protection on regular contract) from the top quartile (e.g. South Korea) to the median (e.g. Norway) would increase the valueadded share of industries with a structurally high job turnover by 0.15 percentage points (Figure 12). The overall effect of greater specialisation on growth in sectors with high job-turnover depends on the characteristics of these industries, with some of these industries being more likely to add to growth than others.

Figure 12. Policies and institutions influence industrial value-added shares

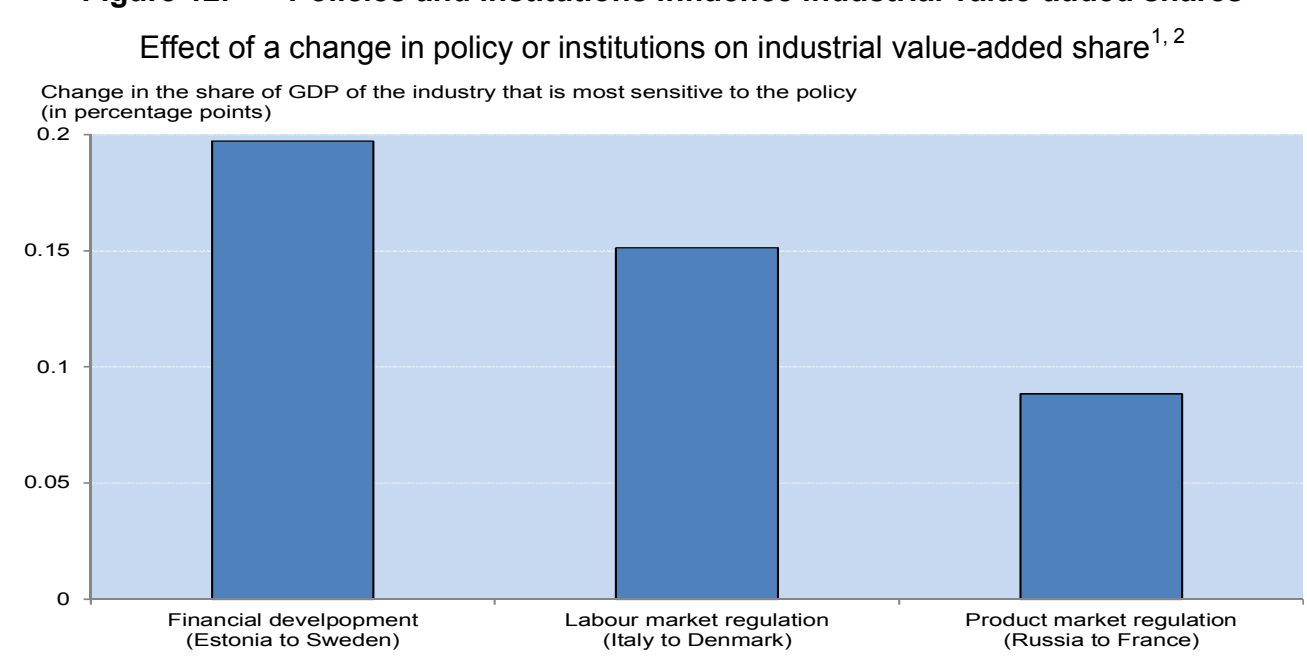

1. The bars show the percentage point increase in the value-added shares of the industry at the $90^{\text {th }}$ percentile level of sensitivity to the policy/institution, when comparing the country at the median with the country at the $75^{\text {th }}$ percentile of the distribution of the policy.

2. Financial development is measured by domestic credit to the private sector as a share of GDP from the World Bank Development Indicators, labour market regulation is measured by the OECD index of employment and protection legislation product market regulation is measured by the OECD index of regulation in product markets (see Johansson and Olaberría, 2014 for details).

Source: OECD estimates.

\subsection{Raising skills can facilitate knowledge-intensive specialisation and affect inequality}

33. By improving the level and quality of education countries can strengthen their relative comparative advantage in knowledge-intensive sectors and thereby increase trade in goods with higher value-added. It could also facilitate specialisation in higher value-added activities within a supply chain, as higher-value-added activities are often concentrated in those parts of the value chain making intensive use of human capital and knowledge-based capital (OECD, 2013a). Estimates suggest that improving the stock of human capital (measured by average years of schooling) from the position of the median country to that of the country at the $75^{\text {th }}$ percentile of the distribution (corresponding to an approximate three years' 
increase in average years of schooling), could increase total exports by $15 \%$ (Figure 1A). This effect can be up to $21 \%$ in industries that are intensive in high-skilled labour (at the $90^{\text {th }}$ percentile), such as electronics (Figure 1B). Thus, a greater stock of human capital could raise trade and facilitate climbing the value-chain towards higher skill and higher value-added activities, with positive effects on growth.

34. Studies suggest that encouraging more students to pursue tertiary education has ambiguous effects on the wage gap between skilled and unskilled workers. These reforms tend to widen income dispersion by increasing the number of high-wage earners (OECD, 2012c). However, research suggests that this effect may be more than offset by a decline in the returns to higher education relative to lower levels of education as the relative supply of higher skilled workers increase (Koske et al., 2012). Lower relative returns could mitigate investment in tertiary education and the supply of skilled workers putting downward pressures on the wage gap. At the same time, continued knowledge-driven growth could mean that the demand for skilled labour may outstrip the supply of skills, and this may lead to a rise in earnings inequality (Braconier. 2014). Furthermore, education policies that promote equity and support disadvantaged students in achieving better academic outcomes may also help reduce income inequality in the future (OECD, 2010b; Braconier et al., 2014).

\section{Trade and specialisation scenarios to 2060}

35. Scenarios of likely developments in trade and specialisation over the next 50 years are based on a framework that combines long-term macro projections for the world economy with a detailed sectoral trade model that replicates the key stylised facts concerning the driving forces of trade and specialisation patterns described in the previous sections. ${ }^{9}$ Macro projections are based on OECD's long-term projections for GDP, saving, investment and current accounts (OECD, 2013b and Johansson et al., 2012) for OECD and non-OECD G20 countries, complemented with projections by Fouré et al., 2012 for other countries. The trade model is a computable general equilibrium (CGE) model designed to analyse the evolution of bilateral trade patterns and sectoral specialisation in the global economy. For tractability, the 147 countries and 57 industries covered in the CGE trade model are aggregated into 26 regions and 25 sectors respectively (see Box 7 and Château et al., 2014 for more details). The combination of aggregate projections, which are based on a growth model, with the more detailed description of behaviour of consumers and firms provided by the CGE model allows highlighting how countries' specialisation is shaped by global trends (e.g. ageing, skill enhancement, capital investment, technology diffusion, etc.) and how structural and macro policies implemented in each country will affect future trade and specialisation patterns, taking into account inter-linkages across countries.

36. Evidence suggests that policies and institutions can affect trade and specialisation. Reflecting this, both the aggregate and the sectoral model used in the analysis embody different channels through which public policies can influence economic behaviour and performance (see Appendix 3 for details). Growth projections account for the impact of developments in labour market and retirement policies (such as reforms to lengthen working lives in line with gains in longevity) on unemployment and labour force participation, regulatory and competition policies on productivity (such as continuing liberalisation of product markets), expansion of educational systems on human capital formation, as well as for the influence of fiscal consolidation (which is assumed to stabilise debt at or below $60 \%$ of GDP) in advanced economies and enhanced welfare policies in emerging economies (i.e. resulting in increased social spending) on savings, investment and current accounts. Besides affecting trade and specialisation through

9. Drawing long-run scenarios is inherently difficult as assumptions have to be made on the future evolution of the drivers of growth and some areas (e.g. repercussions of climate change) cannot be foreseen and incorporated in a model-based analysis. Thus, the numbers presented here should be interpreted as a stylised scenario resulting from a number of assumptions concerning trends and relationships among drivers of specialisation and growth rather than as any attempt at providing a long-run projection. 
growth, a number of these structural and macro policies will also have implications for specialisation by affecting the allocation of resources across sectors. These allocative effects are only partially taken into account in the analysis.

37. The findings in Sections 2 and 3 highlighted the importance of trade barriers for past developments in trade and specialisation. Consistent with this, the projections consider the impact of trade policies on trade and specialisation through their impact on factor prices and trade costs. More specifically, the CGE model relies on detailed data on bilateral protection and trade cost, including tariffs, regulatory barriers in services (i.e. ad valorem tariff equivalents) and agricultural support (e.g. decoupling subsidies from production). The model is calibrated on the current trade policy stance at disaggregate detailed sectoral level for the countries covered in the model. The projections also account for implemented and agreed regional trade agreements (e.g. enlargement of the European Union, ASEAN, etc.) in the baseline. Furthermore, the CGE baseline projections assume that international transaction costs for goods will gradually fall over time reflecting technical progress in handling at customs (see Appendix 3 for details).

38. The remainder of this section is organised as follows. First a baseline scenario for global trade and specialisation up to 2060 is described. Alternative scenarios are then discussed, focusing on how trade policies and accumulation of human capital in emerging economies can affect trade volumes, trade specialisation, GDP and real income.

\section{Box 7. The modelling framework}

The methodology used to design trade scenarios to 2060 combines two models: the long-run growth model in the OECD Economic Outlook (Johansson et al., 2013; OECD, 2013b) and a version of MIRAGE, a multi-country, multisector dynamic model, developed by the Centre d'Etudes Prospectives et d'Informations Internationales (CEPII) (Fontagné and Fouré, 2013, for details see Château et al., 2014).

The long-run growth model

The long-run growth model provides long-run projections for 42 countries for potential output based on a CobbDouglas production function with constant returns to scale featuring physical capital, human capital and labour as production factors plus labour-augmenting technological progress. The model relies on conditional convergence, in which each country is expected to converge to its own steady-state in the long-run. By assuming convergence in total factor productivity and human capital, the model projects trends for the production factors and GDP out to 2060. The degree of convergence in total factor productivity depends on the starting point, with countries farther away from their technology frontier converging faster, but it also depends on the country's own structural conditions and policies (i.e. country-specific technological frontier). In the long run, if all countries grow at the same rate determined by the worldwide rate of technical progress, cross-country GDP per capita gaps would remain, mainly reflecting differences in technology levels, capital intensity and human capital. These in turn partly depend on differences in structural conditions and policies.

Private savings rates for OECD countries reflect demographic developments, captured by old age and youth dependency ratios, with additional effects from fiscal balances, the terms of trade, productivity growth, net oil balances and the availability of credit. Total savings are then determined as the sum of public and private savings, assuming a $40 \%$ offset of any improvement in public savings from reduced private savings. Short-term interest rates vary with the state of the cycle; once the output gap is closed, they depend on the country-specific inflation target, on the growth rate of potential output and on a global balancing premium which keeps the global sum of current account balances stable. The long-run interest rate is determined as a forward combination of short-term interest rates over the next 10 years and a fiscal risk premium. Through the global interest rate balancing premium, movements in long-term interest rates ensure that global saving and investment remain aligned, whereas imbalances at the national level are reflected in current account balances. The fiscal side of the model ensures that government debt-to-GDP ratios stabilise over the medium term. This is achieved through alternative fiscal closure rules for the primary balance which either stabilise debt through a gradual improvement in the primary balance or target a specific debt-to-GDP ratio, which is $60 \%$. Debt service responds to changes in debt and market interest rates, but with lags which reflect the maturity structure of debt.

\section{MIRAGE model}

The projections of the long-run growth model are imposed on MIRAGE-e, a version of the computable general equilibrium (CGE) MIRAGE model dedicated to long-term foresight, trade policy and energy-related analysis. The advantage of the MIRAGE-e model is that it models bilateral trade relations at a detailed level (calibrated on GTAP 
data) and relies on comprehensive measures of bilateral protection and trade barriers sourced from the MAcMap database (Bouët et.al., 2004). These features make it specifically suited for trade policy simulations. MIRAGE-e provides a fully consistent and theoretically founded projection of changes in consumption patterns, resource allocation and sectoral GDP composition, at the regional and country level, for 147 regions of the world, based on a detailed description of bilateral trade flows.

MIRAGE-e, as all CGE models, is micro-founded. The model's micro-founded equations represent the behaviour of agents in a consistent neo-classical framework together with macroeconomic closure rules. In MIRAGE, a representative agent is maximising its utility relatively to the perceived set of prices and firms maximising their profit. Specifically, the demand side is modeled through a representative consumer from each region that maximisses its intra-temporal utility function under its budget constraint. This representative agent saves a part of his income and the rest is spent on goods according to a Linear Expenditure System - Constant Elasticity of Substitution function. Goods are differentiated by their origin, with the substitution between domestic and foreign goods depending on their relative prices given by so-called Armington elasticities. The projected savings rates are imposed on MIRAGE according to the estimations of the long-run growth model, whereas the allocation of investment across sectors remains endogenous. Each sector is modeled as a representative firm, which combines value-added and intermediate consumption in fixed shares. Value-added is a bundle of imperfectly substitutable primary factors (capital, skilled and unskilled labor, land and natural resources) and energy. All primary factor endowments of countries are supposed to be fully employed and their growth rates are determined exogenously from the long-run growth model. Installed capital stock is assumed to be immobile (sector-specific), while investment, which represents the long-run adjusting possibilities of a capital market, is allocated across sectors (perfect mobility) according to their rate of return to capital. Skilled labor is perfectly mobile across sectors, while unskilled labor is imperfectly mobile across agricultural and other sectors. Land is assumed to be imperfectly mobile between agricultural sectors. Natural resources are sector-specific.

\subsection{Global growth will be sustained by emerging economies}

39. Over the next half century, world GDP is projected to grow on average at around $3 \%$ per year with declining rates in many countries. Up until 2030, world growth will be sustained by a rising weight of China and India with high, albeit declining, growth while after 2030 fast growth in Africa is expected to support world growth. The OECD trend GDP growth is projected at about $2 \%$ annually until 2060, and growth in emerging economies will continue to outpace the OECD, but the difference will narrow over coming decades as income levels in emerging economies catch up to those in the OECD. As a result, the next 50 years will see changes in country or region shares in global GDP (Figure 13). The faster growth rates in emerging economies imply that the combined GDP of present non-OECD economies will account for around 60\% of world GDP at current PPPs by 2060, up from about 40\% in 2010 .

Figure 13. Major changes in the composition of world output over the next $\mathbf{5 0}$ years

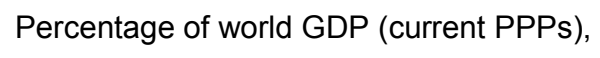

2060
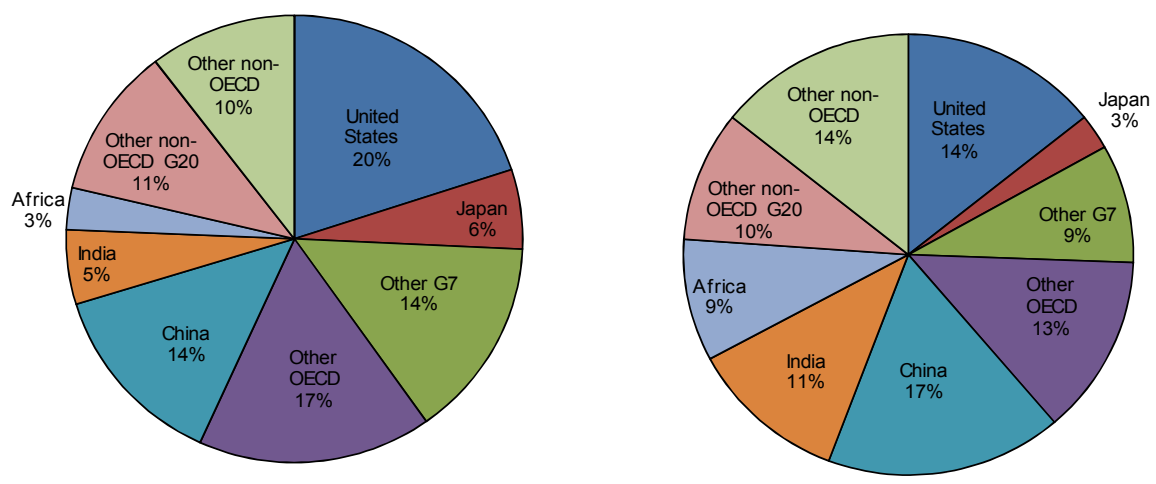

1. World GDP refers to 147 countries

Source: Calculations based on the long-term model and MAGE. 


\subsection{Continuing globalisation over the next half century}

40. Growth in trade (gross exports of goods and services) is expected to continue to outpace GDP growth over the next 50 years with world trade estimated to grow at around $3.5 \%$ annually (compared with $6.9 \%$ over the period 1990-2007). Projections imply that the trade elasticity with respect to GDP is expected to be lower than in the decades before the financial crisis, which partly reflects that the contributors to world growth over the next half century will rely less on export-led growth than in the past decades and partly because the intensity of fragmentation of global value chains is hypothesised to slow down as there are likely physical limits on how much a product and task can be fragmented (Fontagné and Fouré, 2013).

41. In terms of geographical distribution, there will be large shifts in trade patterns, reflecting among other things uneven developments in income across the globe as well as changes in the composition of the consumption basket and relative productivity (Figure 14). China and India are projected to gain market shares in world trade over the next half century, although the rapid growth in China's trade share is expected to slow down after 2030, as GDP growth is slowing. Likewise, Africa, Indonesia and other Asian economies are projected to experience sizeable increases in trade shares, especially after 2030, reflecting rapid growth leading to larger economic size combined with low production costs. These gains in trade shares of emerging and developing economies are mostly at the expense of reduced trade performance within the Euro area. From having accounted for 19\% of world exports in 2012, the Euro area's market share in exports is expected to fall to approximately $12 \%$ by 2060 . By contrast, some OECD economies, including the United States and Canada, are projected to see their trade shares decrease only slightly, reflecting comparatively more favourable growth projections than the euro area.

Figure 14. The share in global exports of non-OECD countries will increase significantly

Gross exports as a share of world exports, \%
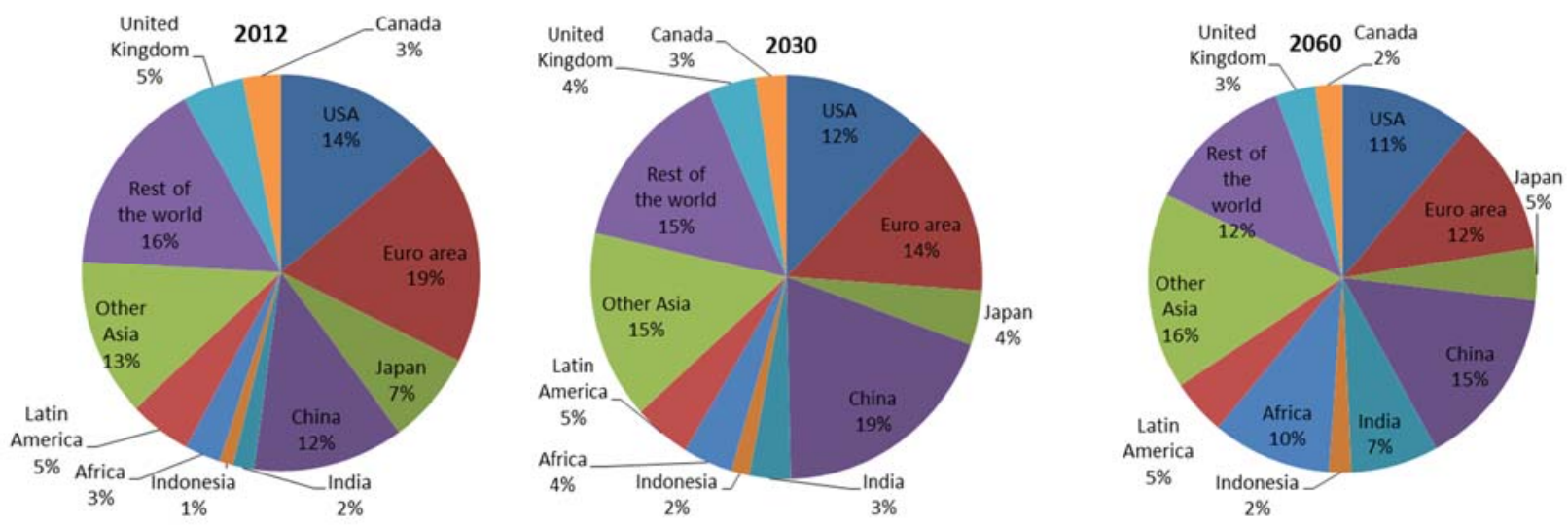

Source: Calculations based on MIRAGE.

42. The changing geographical distribution of trade is mirrored by changes in the relative importance of different constellations of trading partners (Figure 15). While in 2012 about half of total trade in bilateral terms took place within the OECD area, the importance of bilateral trade among OECD members is expected to nearly halve by 2060 . Instead, by 2060 trade among non-OECD economies will more than double, to account for approximately one-third of global trade. For instance, trade among Asian economies increases from around $6 \%$ to $16 \%$ over the projection period. At the same time, OECD economies will increasingly import products from non-OECD economies, whereas the share of global imports of nonOECD from OECD countries will remain more or less unchanged. All in all, over the next 50 years the geographical centre of trade is projected to move away from OECD to non-OECD countries. 
Figure 15. A growing share of trade will occur among non-OECD countries

Gross exports, \%

2012

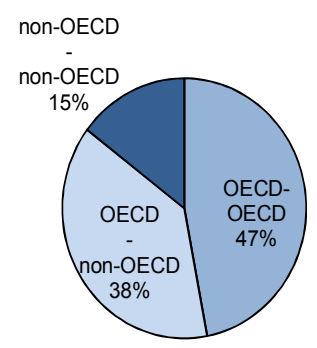

2060

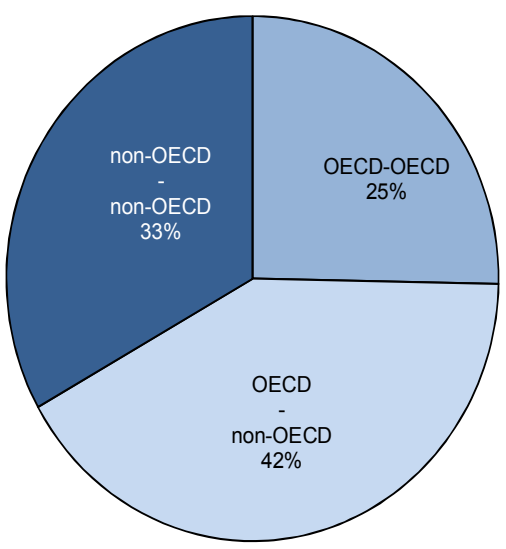

Source: Calculations based on MIRAGE

\subsection{Globalisation and income convergence will influence trade and industrial specialisation}

\section{Shift in trade shares}

43. The relative importance of different countries and regions in specific markets is set to change markedly over the coming decades, driven by diverging growth performance, changes in relative productivity and production prices as well as a reorientation of consumption in emerging economies towards services (Figure 16). Notably, China, India, other Asian economies and Africa are projected to become the dominant players in manufacturing, while most OECD countries are expected to lose ground. For instance, Japan, South Korea and the United States are set to lose their comparative advantage in electronics to China and other Asian countries (see Appendix 4, Figure 1), who could account for as much as $70 \%$ of world exports in electronics by 2060 . However, the long-run trends for detailed sectors should be interpreted with caution, given that the model-based scenario cannot foresee and incorporate developments in all areas.

44. Emerging and developing economies' (e.g. China, India and Africa) world market shares will increase significantly even in service trade, as a result of a shift towards more advanced activities as these economies become wealthier, combined with a larger economic size. The gain in service trade shares in China and India is mostly at the expense of the Euro area, the United States, Japan and the United Kingdom. One explanation for this is that some service sectors are typically characterised by low productivity levels. Therefore, access to low-cost labour matters comparatively more for these sectors than others and, despite rising labour cost in emerging economies, the cost is still lower than in some advanced economies.

45. In the energy sector, a marked shift in the global distribution of trade is expected to occur over the next half century. The trade share of the United States in world energy exports is expected to more than 
triple by 2060, at the expense of the Middle East and the Russian Federation. This large gain reflects investments in technologies to extract and develop new sources of shale gas and oil as compared with the exhaustion of conventional natural reserves in other parts of the world (e.g. IEA, 2012). Alongside the increase in energy trade, the United States maintains competitiveness in complementary industries such as chemicals (see Appendix 4, Figure 1). However, it should be noted that the energy sector is subject to large geopolitical and technological uncertainty over the next half century, making projections particularly vulnerable to unpredicted events.

46. In agriculture, the United States and other Asian countries are expected to remain competitive and their trade share in agricultural exports will increase mostly at the expense of Africa and Latin America.

Figure 16. The relative importance of different countries in specific industries are expected to change ${ }^{1}$

Countries' share in world exports by industry, 2010 and $2060 \%$

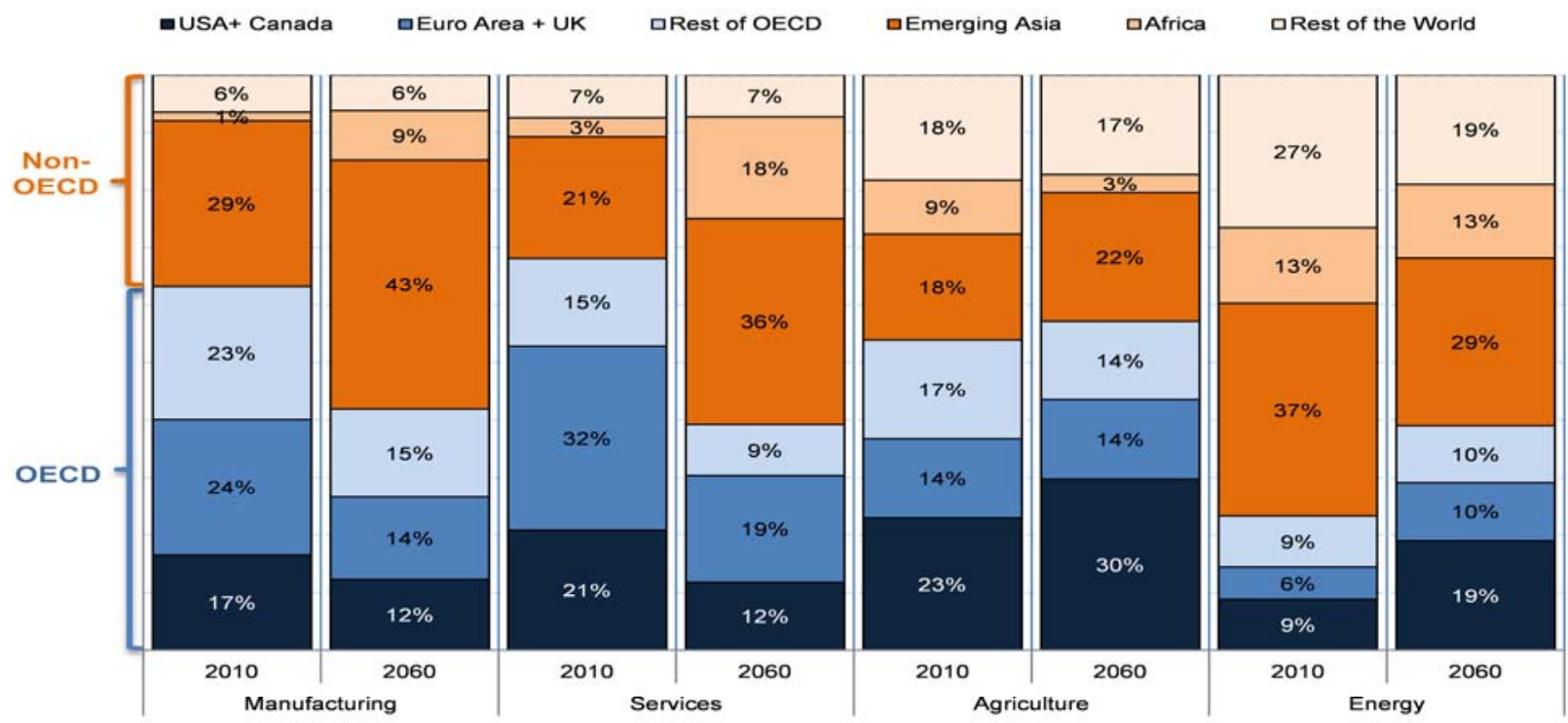

1. Manufacturing includes chemicals rubber and plastic, electronics, food, iron and steel, metal products, other manufacturing, other metals, other minerals, paper and wood, textiles, transport equipment. Service includes business service, transport service, wholesale and retail, public administration and other services. Agriculture includes livestock, rice and crops, other agriculture and other mining. Energy includes coal, crude oil, electricity, gas and refined oil.

Source: Calculations based on MIRAGE.

\subsubsection{The industrial structure in emerging economies gradually becomes similar to that of the OECD}

47. In parallel with the changing trade patterns, the industrial structure (measured as value-added shares of specific sectors in total value-added) will evolve differently across countries and regions depending on changing patterns of domestic and international demand, differences in the accumulation of production factors across countries, the allocation of factors across sectors within countries and countries' international competitiveness. One general trend that stands out in the baseline projection is that most significant changes will occur in emerging economies, whereas the industrial structure will remain relatively stable in OECD countries over the next half century (Figure 17). This largely reflects the development process in lower-income countries with income and living standards catching-up towards levels of higher-income OECD countries, which results in changing domestic demand and consumption 
patterns. Projections also show that trade costs remain large enough in certain industries to prevent a full shift of industrial activities to emerging economies away from OECD.

48. In fast-growing emerging countries past trends are expected to continue over the projection period and the industry mix will continue shifting towards services away from manufacturing, typically low-skilled (e.g. textile, food production etc.). China and India are projected to experience marked increases in the contribution of financial and business services, wholesale and retail and transport services to value added as demand for these services increases with income combined with trade frictions (Figure 17). This largely reflects the development process in lower-income countries with income and living standards catching-up towards levels of higher-income OECD countries, which results in changing domestic demand and consumption patterns.

Figure 17. Industrial structure is set to change in emerging economies

Value-added shares of different sectors in China, India and Indonesia, 2010 and 2060

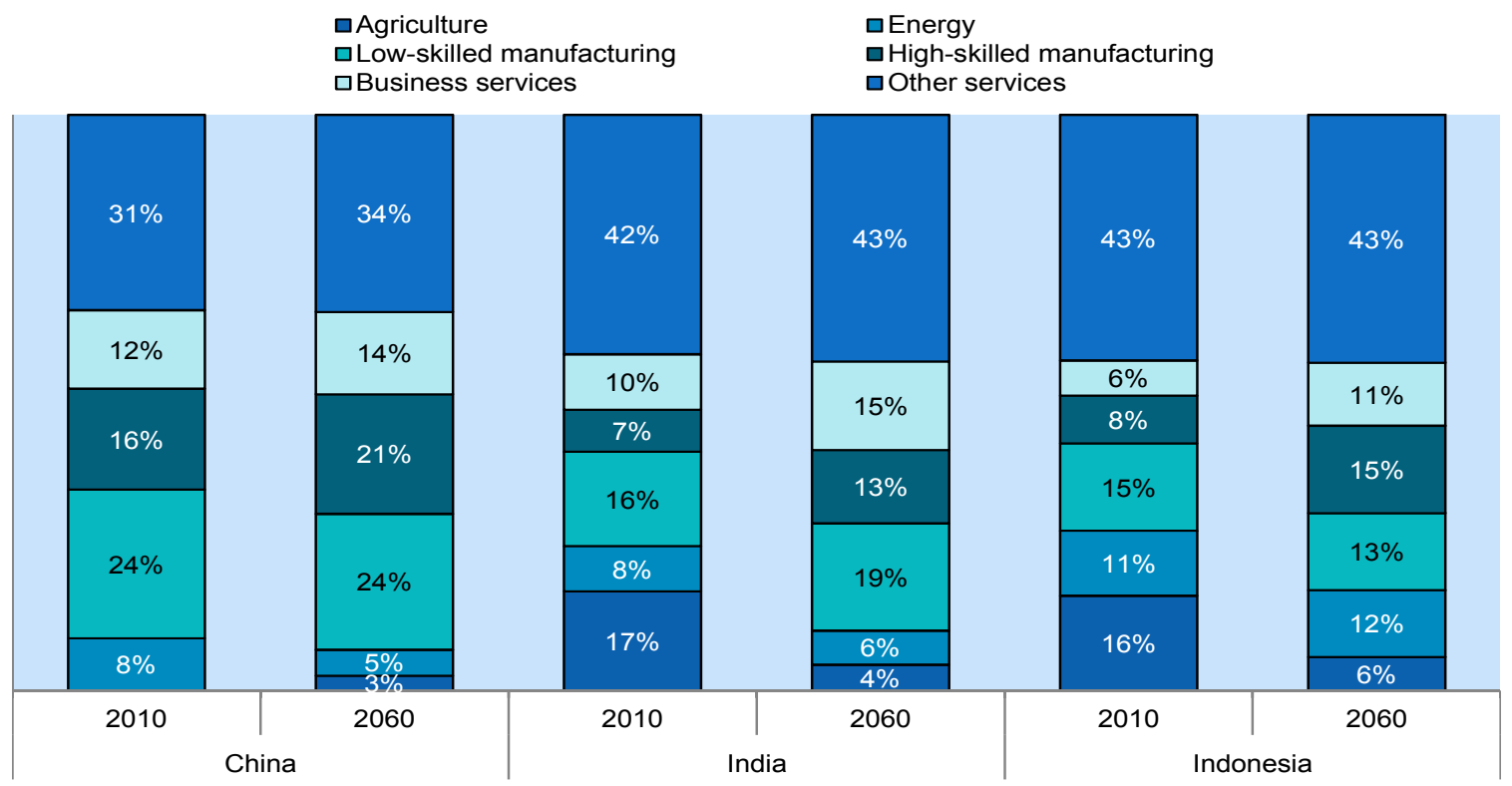

1. Agriculture includes rice and crops, other agriculture and other mining. Energy includes coal, crude oil, electricity, gas and refined oil. Low-skilled (low-technology) manufacturing includes food, textile, paper and wood, other manufacturing, metal products, other metals and other mining. High-skill (high-technology) manufacturing includes chemicals, iron and steel, transport equipment and electronics. Other services include transport service, wholesale and retail, public administration and other services.

Source: Calculations based on MIRAGE.

\subsection{Income convergence will influence wage inequality among and within countries}

49. Over the next 50 years income gaps among countries will narrow. Rapid GDP growth in emerging economies is matched by a tendency of GDP per capita to converge across countries. Between now and 2060, GDP per capita (measured in 2005 PPPs) in India, Philippines and some African countries will increase by more than 7 times, while the increase is around 5 times in Indonesia and China. Over the same period, living standards will roughly double in the highest-income OECD countries. This will lead to a richer and more equal distribution of world income among countries, which will push in the direction of falling absolute poverty.

50. Furthermore, across countries the relative wage of skilled to unskilled labour will change over the next half century, with implications for trade patterns. As highlighted in Braconier et al. (2014) the 
evolution of the relative wage earnings of different workers depends on several factors including the amount of investment in tertiary education. Indeed, the projected relative wage varies with the pace of investment in skills. For example, if educational attainment in emerging economies were to converge at a slower pace (i.e. $50 \%$ slower) than assumed in the baseline due to lower investment in education, the relative wage of skilled to unskilled labour will tend to increase in these countries as compared with the baseline (see below for the implications on trade). Since a sector's production price varies according to its skill intensity less skill-intensive sectors will face a decrease in their price, while more skill-intensive an increase. The induced change in production prices reshapes a country's comparative advantage and this influences trading partners' demand for its goods (as well as for goods originating in all other countries). However, the spillover of lower supply of skilled workers in emerging economies on wage growth in other countries is limited. This reflects a substitution of skilled labour for other production factors mitigating the impact on producer and international prices from the wage change and, in turn, on foreign demand (production and consumption).

51. The distribution of wages across differently skilled workers within countries depends on the supply and demand for skills, the extent of skill-biased technological change, the composition of consumption demand and institutional settings in labour markets and educational systems. Over the next half century educational attainment will continue to improve, increasing the supply of skilled labour, and thereby putting downward pressure on the skill premium. However, as shown in Braconier et al. (2014) continued skill-biased technological progress, with rapidly rising demand for higher skills, is likely to outpace the increase in the supply of skills, leading to increased wage inequality over the next 50 years. If skill-biased specialisation continues at the same pace over the next 50 years as during the period 19952009 , this would more than offset the downward pressure on relative wages stemming from an increased supply of high-skilled workers. Indeed, during the period 1995-2009, the upward pressures of skill-biased specialisation on the relative wage gap between skilled and unskilled workers were on average about 1.5 times greater than the downward impact of increasing supply of high-skilled workers (Figure 9).

\subsection{Trade liberalisation can increase global trade and growth}

52. Despite reductions in market- and non-market barriers to trade during the last decades, particularly for industrial products, significant barriers still remain at the global level. These barriers go beyond tariffs on goods. Regulatory obstacles to trade in services, agricultural subsidies and transaction costs on goods remain large. Removing trade barriers can improve GDP and welfare, while also having side effects on income distribution; for instance, amplifying within-country wage inequality even as it reduces average income gaps across countries. While trade liberalisation can take different forms, the approach in this section is to describe two stylised alternative trade facilitation scenarios, and to gauge the impact of these on global trade, GDP, real incomes, industrial structure and wage inequality over the next 50 years, compared with the baseline long-run scenario described above.

53. Trade liberalisation can occur at global or regional level. It is well known that multilateral negotiations among a large set of countries are inherently difficult, whereas regional trade agreements among a limited group of relatively similar countries can allow for negotiating rules and commitments that go beyond what would be possible in a wider forum. However, a regional agreement can lead to trade discrimination and welfare losses in some countries. To the extent that it generates a diversion of production from efficient producers outside the regional agreement to inefficient ones within the region, it may cause efficiency losses. It can also promote regionalism, potentially hindering trade liberalisation at a global level.

54. Two illustrative scenarios are considered, one with strengthened regional integration among a set of present OECD economies (e.g. the United States, Canada, Mexico, the European Union, Switzerland, 
Iceland, Australia, New Zealand, Japan and Korea), and another with trade liberalisation on a global basis (see Box 8 for details):

- The so-called "regional liberalisation" scenario assumes significant reductions in tariffs and nontariff barriers in services among the members of the free-trade zone, in combination with reductions in transaction costs for goods; at a later stage, in 2030, the free-trade zone is assumed to sign bilateral trade agreements with key partner countries (such as China and India).

- The so-called "partial multilateral agreement" scenario is global but assumes less extensive reductions of trade barriers than in the regional liberalisation.

\section{Box 8. Assumptions in the alternative trade policy scenarios}

The two trade scenarios include the following assumptions:

Regional liberalisation:

- A free-trade agreement (FTA) is established in 2012 between United States, Canada, Mexico (NAFTA), the European Union, Switzerland, Iceland and Liechtenstein (EFTA), Australia, New Zealand, Japan and Korea. Trade barriers (tariffs, transaction costs such as handling at customs and regulatory barriers to trade in services measured by ad valorem tariff equivalents) are progressively phased out in this region.

- In the FTA, tariffs on goods are abolished by 2060 and transaction costs for goods are reduced by $25 \%$ more than in the baseline by 2060 .

- Regulatory barriers in services as measured by ad valorem tariff equivalents converge to half the average intra-European Union level for non-EU countries within the FTA, while barriers between EU members are reduced by a further $10 \%$.

- In 2030, bilateral trade agreements are negotiated with key partners of the FTA including South Africa, The Russian Federation, Brazil, China, India, Indonesia, other ASEAN countries and Chile. With these countries, the FTA bilaterally reduces tariffs by $50 \%$ progressively, until 2060 .

Partial multilateral liberalisation:

- From 2013 tariffs on goods are reduced on a multilateral global basis by $50 \%$ by 2060 and transaction costs are reduced by $25 \%$ more than in the baseline by 2060 .

- Regulatory barriers in services converge to half the average intra-European Union level for non-EU countries within the FTA, while barriers between European Union members are reduced by a further $10 \%$.

- From 2013 agricultural support is reduced by $50 \%$ by 2060 in the European Union, the Unites States, Japan, Korea, Canada and in EFTA countries

\subsubsection{Unevenly distributed increases in trade}

55. Projecting the alternative scenarios reveals mostly positive trade impacts across the globe but illustrates the different outcomes of regional versus multilateral approaches to trade liberalisation. World trade (exports) in the regional and partial multilateral liberalisation is $4 \%$ and $15 \%$ higher in 2060 , respectively, although the gains are distributed unevenly across countries or regions in the two scenarios (Figure 18). While the effect of trade liberalisation in FTA members (mostly OECD economies) is to raise trade by around $7-8 \%$ in both scenarios, non-FTA members (mostly non-OECD countries) only enjoy sizeable increases in trade in the multilateral scenario. For these economies the increase in trade is only about $1 \%$ in the regional liberalisation scenario, while multilateral liberalisation could raise their trade on average by $20 \%$. Nonetheless, as in the baseline, in both scenarios the bulk of all trade still occurs among non-OECD (non-FTA) countries or regions at the end of the projection period. 
Figure 18. Unevenly distributed increases in trade in liberalisation scenarios, 2060

$\%$ increase in gross exports as compared with the baseline by $2060, \%$

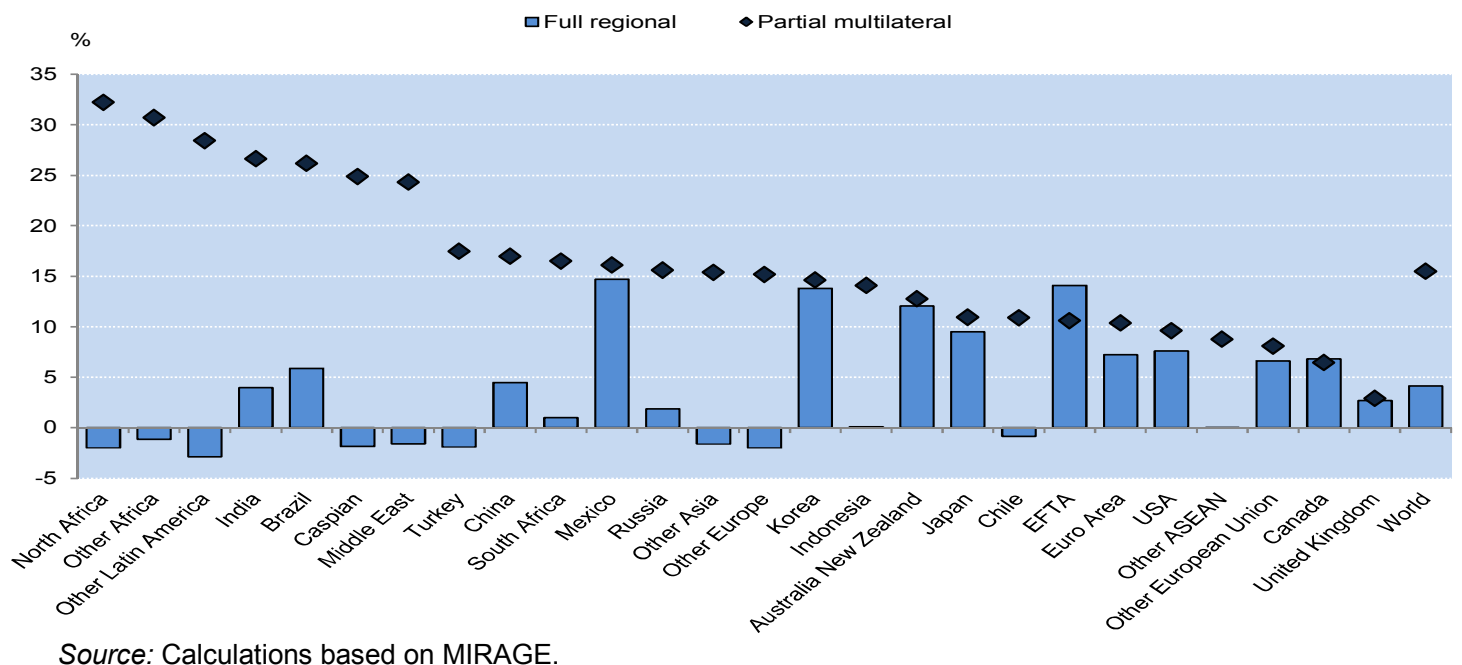

56. This asymmetry in the impact of liberalisation across OECD and non-OECD countries in the two scenarios can be explained by a reorientation of trade and by large trade diversion effects. In the regional liberalisation scenario, a share of potential trade will shift towards members of the FTA (OECD countries) away from non-members (non-OECD countries) (Figure 19). Part of this expansion of trade is replacing former trade of non-members with trade from regional members, as a result of the shift in relative market access conditions. As a result of this trade diversion some non-FTA countries will experience trade losses, particularly those in regions that do not sign a bilateral agreement with the FTA in 2030 (e.g. Africa, Latin America, the Middle East etc.). By contrast, in the partial multilateral scenario trade is instead reoriented away from OECD countries towards the non-OECD area, reflecting comparatively larger reductions in tariffs than in OECD countries (i.e. given that initial tariff levels in the baseline are higher in non-OECD than in OECD), as well as stronger underlying growth performance in this area.

Figure 19. Reorientation of trade towards FTA partners

Export shares in world trade, \%

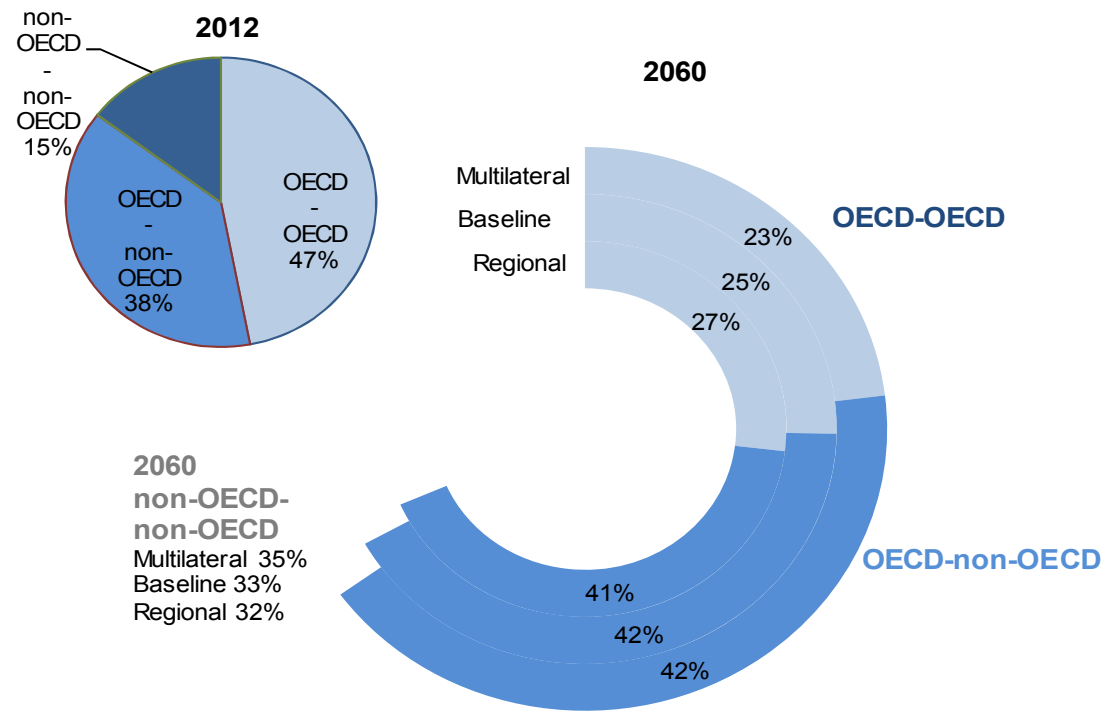

Source: Calculations based on MIRAGE. 


\subsubsection{Trade expansion triggers changes in the industrial structure within countries}

57. Trade liberalisation will increase international competition and induce a reallocation of resources across and within countries and industries, as discussed earlier. However, on the whole, the change over time in the broad industrial structure triggered by deeper trade liberalisation in the two scenarios tends to be moderate compared with that which already occurs in the baseline. This suggests that a larger share of the trade-induced reallocation of activities occurs within rather than between industries.

58. Nonetheless, some interesting patterns emerge. In both alternative scenarios, the industrial structure in the United States tends to shift over time towards agriculture (rice and crops) and food production away from other manufacturing (Figure 20). This reallocation comes about through increased international competitiveness in the export market due to the removal of agricultural support in some countries with currently high levels of support, in combination with an underlying comparative advantage of the United States in this sector due to availability of arable land. By contrast, the removal of agricultural support in the European Union tends to reorient activities in the Euro area away from agriculture towards manufacturing (e.g. the auto industry, other manufacturing, textiles). In Japan, in both scenarios, the industrial structure moves away from agriculture and food production towards manufacturing, particularly transport equipment.

59. Among emerging economies, the change in the industrial structure over the next half century is much more pronounced with partial multilateral liberalisation than with regional liberalisation, consistent with better market access and larger trade gains in the former scenario. One common pattern is a shift towards manufacturing away from agriculture and food production, particularly in the multilateral scenario. For instance, in India and Indonesia, by 2060 the value-added in the electronics sector would increase by more than $8 \%$, compared with baseline. Furthermore, multilateral liberalisation would increase the value-added of the auto industry by around $12 \%$ in India compared with baseline, reflecting a stronger impact of India's competitiveness in labour-intensive low and medium-skilled manufacturing.

Figure 20. Reallocation of industrial activities, 2060

$\%$ increase in value added of industries as compared with the baseline in 2060

The United States

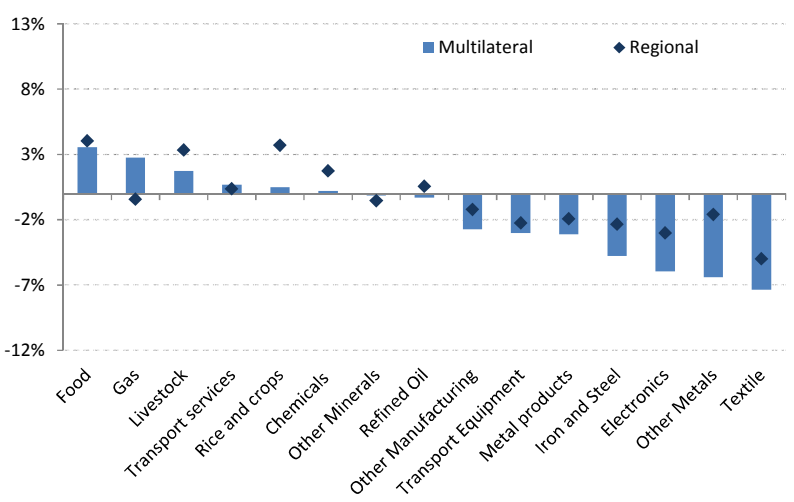

Euro area

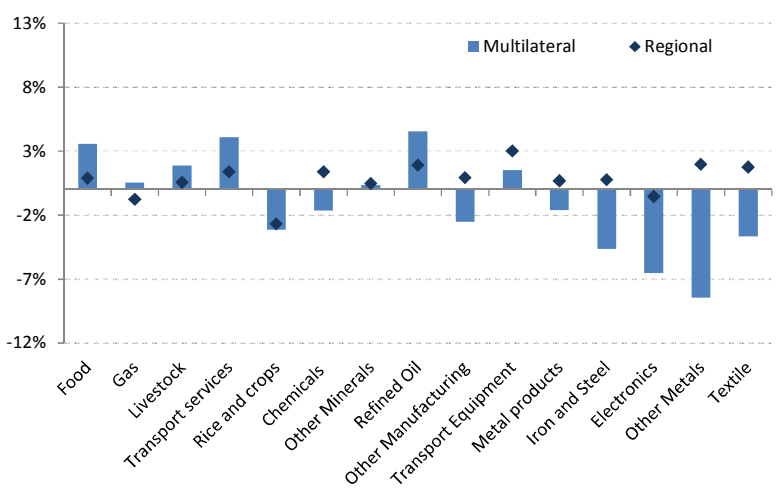



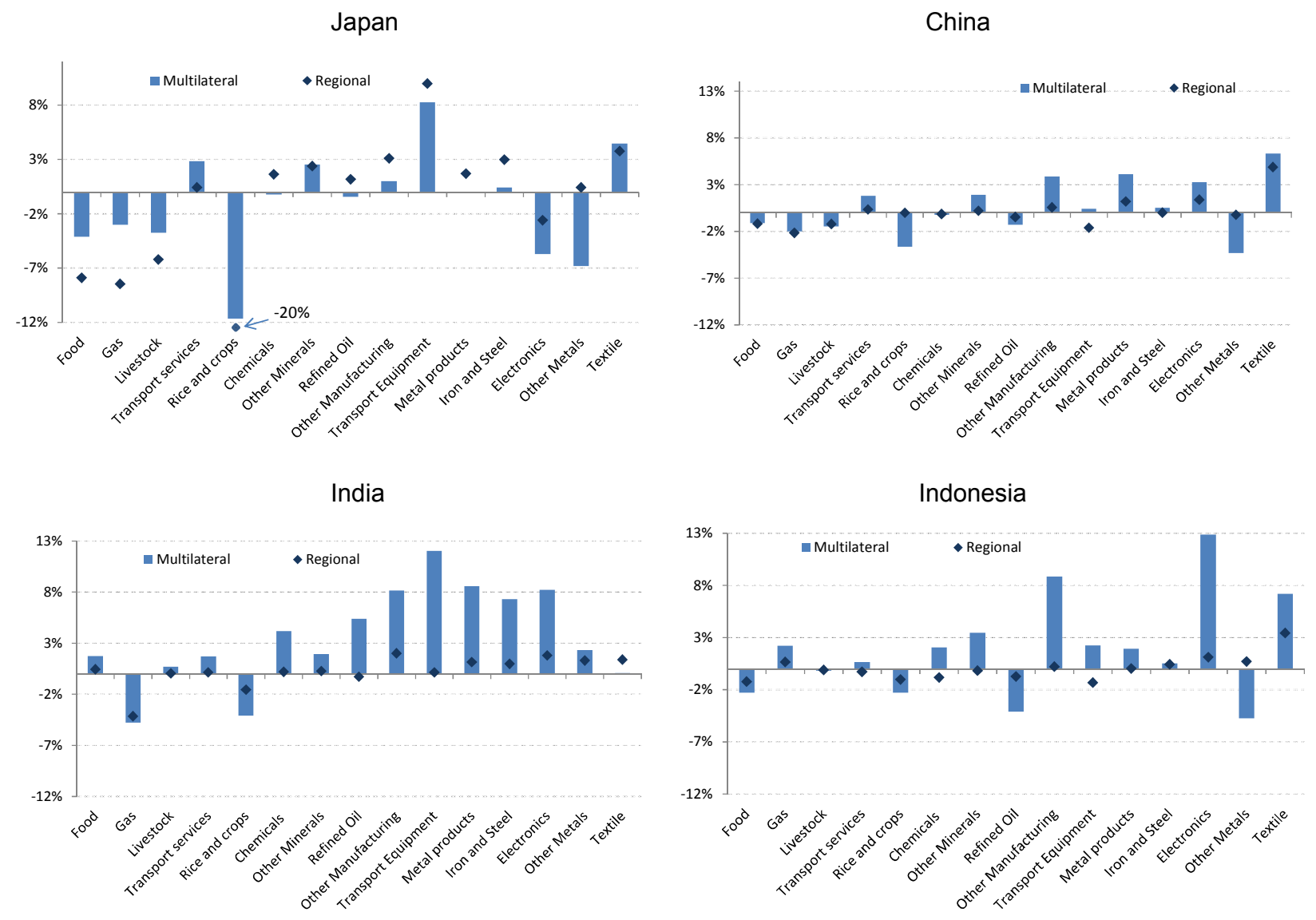

Source: Calculations based on MIRAGE. 


\subsubsection{Reducing trade barriers has a positive impact on real GDP, more so if liberalisation is multilateral}

60. In parallel with the increased trade integration and associated reallocation of resources across sectors to comparatively more efficient ones, long-term real GDP will increase relative to baseline. World GDP in the regional and partial multilateral liberalisation scenarios is $0.6 \%$ and $2.8 \%$ higher in 2060 , respectively. But again, the gains in long-term GDP are unevenly distributed across the globe in the two scenarios. While the change in real GDP in most OECD countries is similar in the two scenarios, the gains are always greater for non-FTA members (mostly non-OECD countries) in the multilateral scenario. Multilateral liberalisation could raise long-term real GDP in India and other Asian regions by more than $4 \%$ by 2060 (relative to baseline) (Figure 21A). The gains in terms of GDP illustrated here may appear modest compared with large changes observed as a result of growth fundamentals (e.g. demography, education, technical progress etc.). However, it should be kept in mind that, while the projections capture only allocative gains, a better trade environment and level playing field are pre-conditions to reap the growth benefits of the mentioned fundamentals. For instance, if feedback effects of increased trade openness on growth in terms of acceleration of productivity catch-up (due to knowledge spillovers and diffusion of technologies) were taken into account in the multilateral liberalisation scenario, GDP would be on average an additional 1.2\% higher in 2060. Thus, world GDP could be as much as 4\% higher in 2060 in the multilateral scenario as compared with baseline. In countries with large scope for productivity catchup, such as emerging economies, the effect of trade openness on productivity could add up to more than $2.5 \%$ to GDP (Figure 21B). For instance, accounting for the effect of rising openness on productivity catch-up, GDP could be $7.6 \%$ and $4.1 \%$ higher by 2060 in India and China, respectively. Even larger effects on GDP could be expected if the full range of dynamic effects were accounted for.

Figure 21. Trade liberalisation increases GDP and welfare, 2060

A. \% increase in real GDP of trade liberalisation as compared with the baseline by 2060

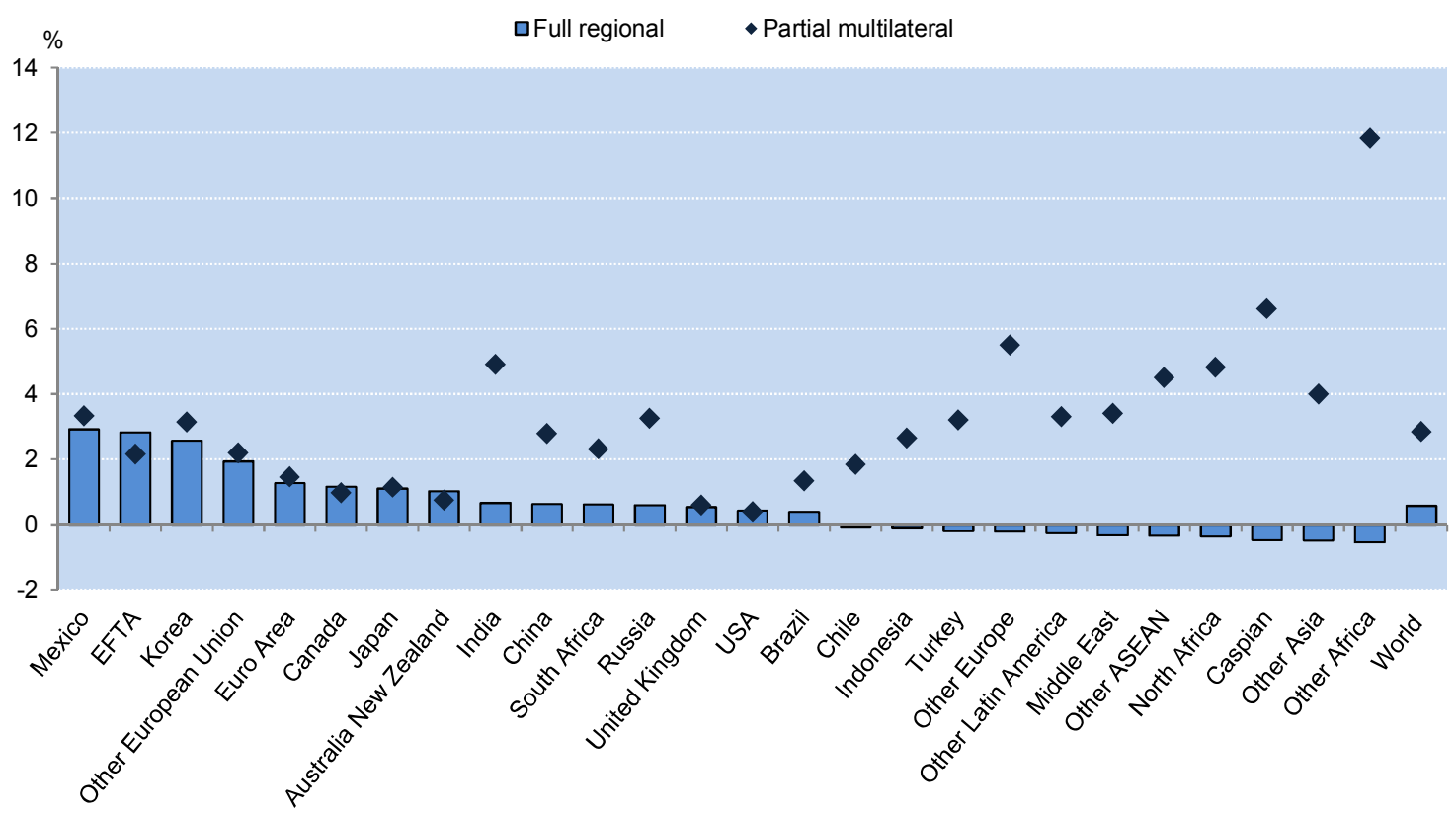




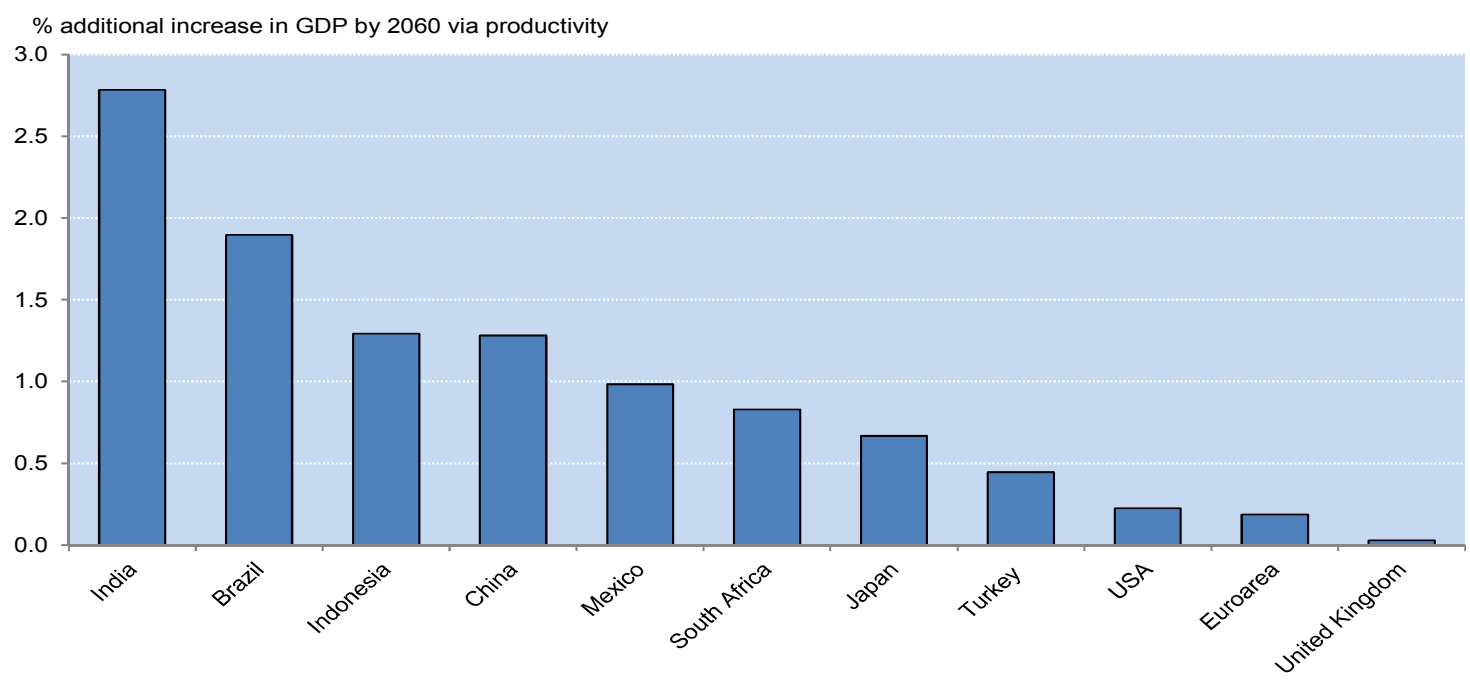

Source: Calculations based on MIRAGE and the Long-Term Growth model.

\subsubsection{Pressures on skill premia tend to increase as trade barriers are removed}

61. Relative wages will be affected by trade liberalisation since the demand for different types of skills changes as the volume and composition of bilateral trade is altered. Overall, there is a tendency for the wage gap between skilled and unskilled workers to widen in both advanced and emerging economies in the trade liberalisation scenarios relative to baseline. In most cases, upwards pressures on skill premia are stronger in the multilateral liberalisation scenario than in the regional one, reflecting greater reallocation of resources across industries and countries towards higher-skilled activities. ${ }^{10}$ Generally, however, the pressures are moderate (Figure 22). Stronger pressures on wage premia are observed in the Euro area and Japan, as demand shifts from low-skilled sectors such as crops towards higher-skilled auto industry, oil refinery and other manufacturing, as well in some other advanced economies (e.g. the United Kingdom and EFTA countries). Pressures on wages of skilled workers are also significant in Indonesia due to the strong reorientation of production towards the relatively high-skilled electronic sector, in combination with comparatively lower up-skilling than in some other emerging economies (e.g. China).

10. It should be kept in mind that the model does not account for any feedback from skill premia to the supply, which could have implications for wage gaps. Also, any existence of shared rents in protected sectors prior to the trade liberalisation is not taken into account. 
Figure 22. Liberalisation puts pressure on skill premia

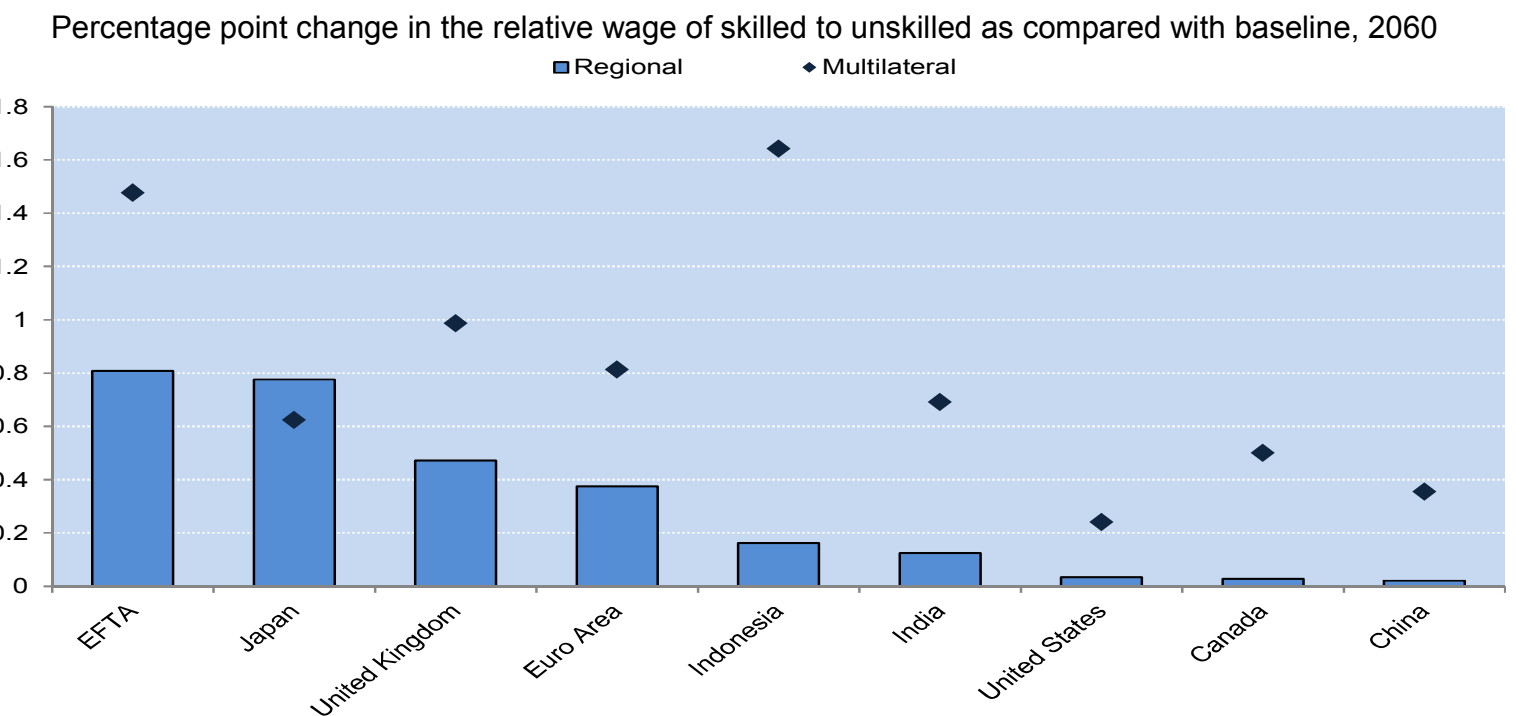

Source: Calculations based on MIRAGE.

\subsection{The speed of up-skilling in emerging economies influences trade and specialisation}

62. The speed of up-skilling has important implications for trade and specialisation across countries. To highlight this, this section compares the baseline trade projection with one in which China, India and Indonesia are assumed to approach the global frontier level of education much more slowly than in the baseline scenario (i.e. by 2060 average years of schooling are around 1.2 years lower than in the baseline). ${ }^{11}$ Changes in the stock of human capital influence aggregate growth and it relative factor prices, especially in these emerging economies, thereby affecting trade and specialisation across countries via scale, gravity and competition effects (Figure 23). Indeed, world trade is some 2\% lower by 2060 in the slower up-skilling scenario as compared with the baseline, mainly driven by decreases in Indian, Indonesian and Chinese exports (ranging between 6-11\%).

11. In this lower up-skilling scenario, the educational attainment of the young cohort in China, India and Indonesia will converge to the frontier level of education at a speed that is $50 \%$ slower than assumed in the baseline macro projections. 
Figure 23. Effects on trade of lower up-skilling in emerging economies, 2060

$\%$ change in gross exports as compared with the baseline by 2060

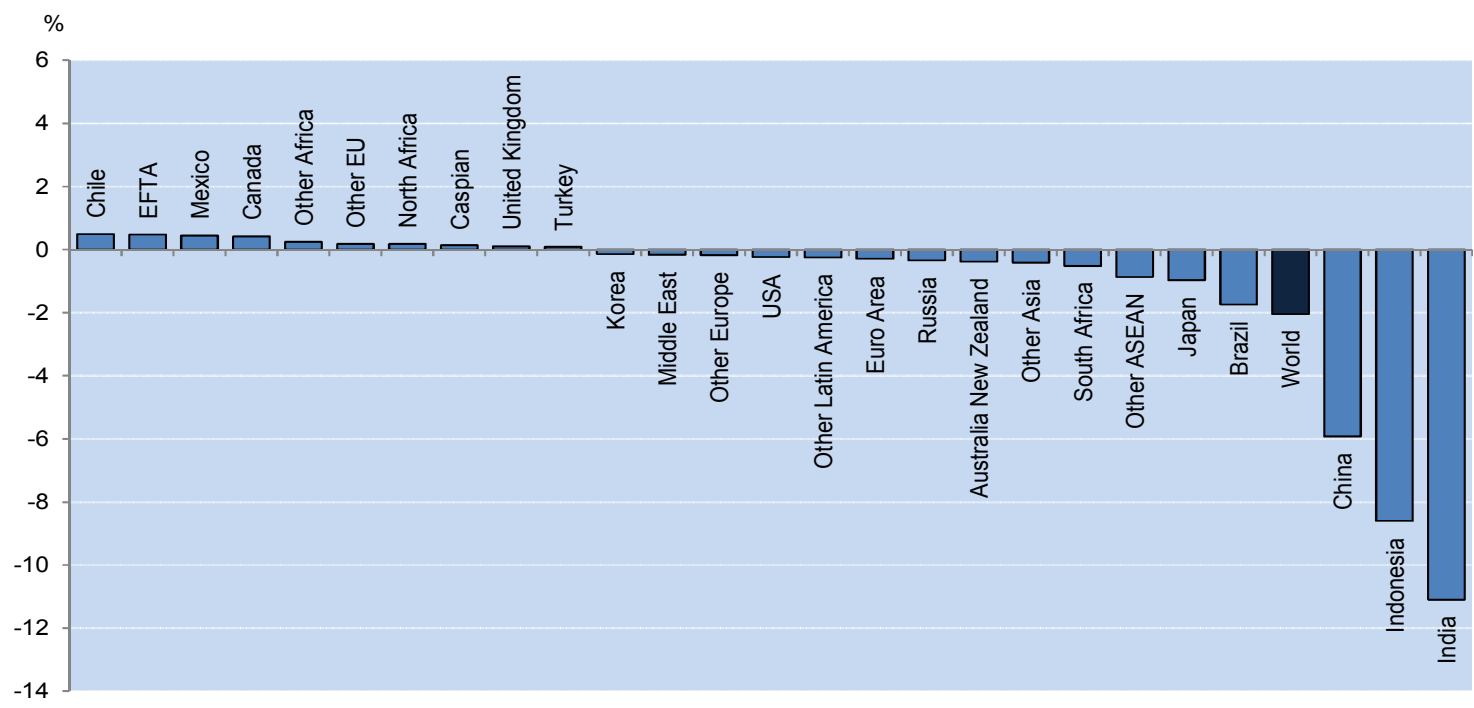

Source: Calculations based on MIRAGE.

63. Slower up-skilling in emerging economies implies that the reorientation of trade and production towards higher-value-added manufacturing and services away from lower-skill activities occurs at a slower pace than in the baseline. For instance, in India and Indonesia by 2060 exports of business services and electronics would be $25 \%$ and $10 \%$ lower, respectively, whereas exports of agricultural goods would be $5 \%$ and $15 \%$ higher, respectively, compared with the baseline (Figure 24). By contrast, slower up-skilling in emerging economies implies that advanced economies (e.g. the United States, Japan and the Euro area) maintain their relative competitiveness in products that are intensive in human capital, such as electronics, business services and other manufacturing.

Figure 24. Slower up-skilling in emerging economies slows down their restructuring towards higher skilled activities, 2060

$\%$ change in volume of industrial exports as compared with the baseline in 2060

China

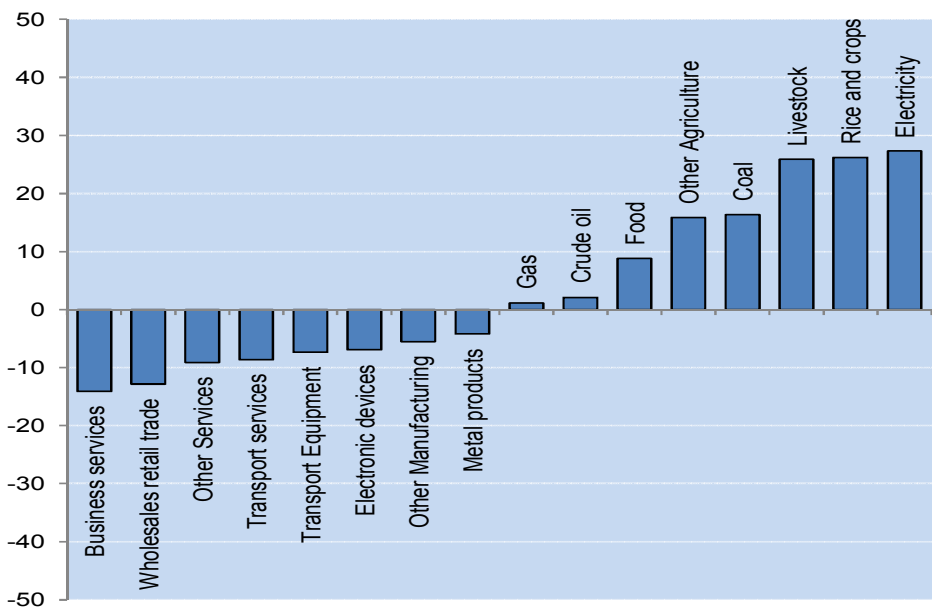




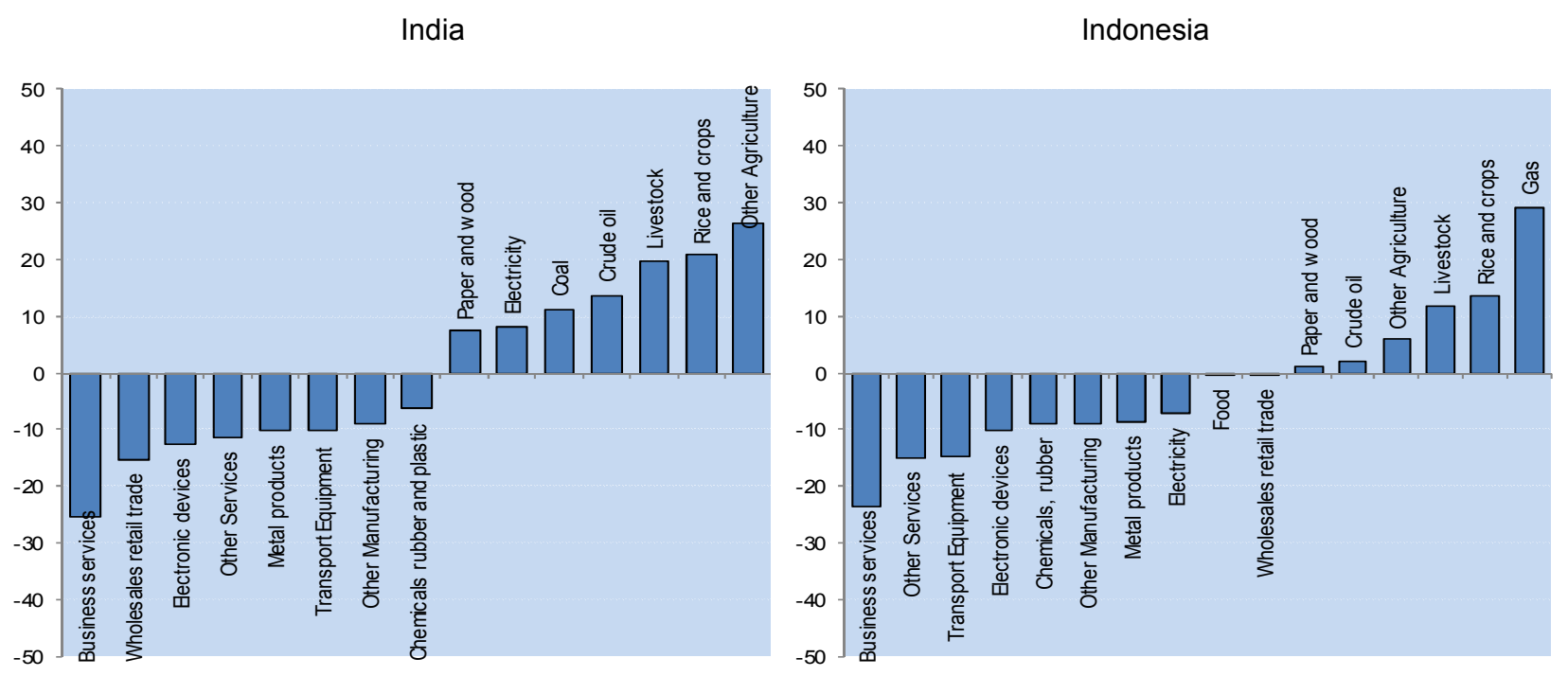

Source: Calculations based on MIRAGE. 


\section{REFERENCES}

Acemoglu, D. (2003), "Patterns of Skill Premia”, Review of Economic Studies, Vol. 70.

Acemoglu, D. and D. Autor (2011), "Skills, Tasks and Technologies: Implications for Employment and Earnings", Handbook of Labor Economics, Vol. 4, Part B, Edited by D. Card and O. Ashenfelter.

Acemoglu, D., A. Pol and E. Helpman (2007), "Contracts and Technology Adoption", The American Economic Review, Vol. 97(3).

Aghion, P. and P. Howitt (1998), Endogenous Growth Theory, Cambridge: Mass.: The MIT Press.

Amable, B. (2000), "International Specialization and Growth", Structural Change and Economic Dynamics No. 11.

Amiti, M. and J. Konings (2007), "Liberalization, Intermediate Inputs, and Productivity: Evidence from Indonesia, The American Economic Review, Vol. 97, No. 5.

Anderson, J.E. and E. van Wincoop, (2004), "Trade Costs", Journal of Economic Literature, Vol. 42, No. 3.

Andrews, D. and C. Criscuolo (2013), "Knowledge-Based Capital, Innovation and Resource Allocation", OECD Economics Department Working Papers, No. 1046, OECD, Paris.

Andrews, D. and F. Cingano (2012), "Public Policy and Resource Allocation: Evidence from Firms in OECD countries", OECD Economics Department Working Papers, No.996, OECD, Paris.

Arnold, J., G. Nicoletti and S. Scarpetta (2008), "Product Market Policies, Allocative Efficiency and Productivity: a Cross-Country Analysis", OECD Economics Department Working Papers, No. 616, OECD, Paris.

Autor, D., L. Katz and A. Krueger (1998), "Computing Inequality: Have Computers Changed the Labor Market?”, Quarterly Journal of Economics, Vol. 113, No. 4, MIT Press, pp. 1169-1213.

Autor, D.H., F. Levy and R. J., Murnane (2003), "The Skill Content of Recent Technological Change: An Empirical Exploration”, Quarterly Journal of Economics, 116(4).

Baldwin, R. (2006), "Globalisation: the Great Unboundling(s)", Economic Council of Finland working paper.

Baldwin, R. and F. Robert-Nicoud (2010), "Trade-in-Goods and Trade-in-Tasks: An Integrating Framework, NBER Working Papers 15882, National Bureau of Economic Research.

Barone, G. and F. Cingano (2011), "Service Regulation and Growth: Evidence from OECD Countries", The Economic Journal, Vol. 121, Issue 555.

Beck, T. (2002), “Financial Development and International Trade. Is There a Link?”, Journal of International Economics 57. 
Behrens, K., G. Corcos.and G. Mion (2011), “Trade Crisis? What Trade Crisis?”, CEPR Discussion Paper No. 7956.

Bems, R., R.C. Johnson and K-M. Yi, (2012), “The Great Trade Collapse”, NBER Working Papers 18632, National Bureau of Economic Research.

Blum, B. (2008), "Trade, Technology, and the Rise of the Service Sector: The Effects on U.S. Wage Inequality", Journal of International Economics, 74 (2008).

Borchert, I. and A. Mattoo (2009), "The Crisis-Resilience of Services Trade", The Service Industries Journal, Taylor and Francis Journals, Vol. 30(13).

Braconier, H, Nicoletti, G. and B. Westmore (2014), "Policy Challenges for the Next 50 years", OECD Economics Department Policy Papers, No. 9, OECD Publishing, Paris.

Bricongne, J-C., L. Fontagné, G. Gauliera, D. Taglioni and V. Vicard (2012), "Firms and the Global Crisis: French Exports in the Turmoil", Journal of International Economics, Vol.87.

Bussière, M., G. Callegari, F. Ghironi, G. Sestieri and Y. Yaman (2011), "Estimating Trade Elasticities: Demand Composition and the Trade Collapse of 2008-09", NBER Working Papers 17712, National Bureau of Economic Research.

Chateau J., L. Fontagné, J. Fouré, A. Johansson and E. Olaberría (2014), “Trade Patterns in the 2060 World Economy”, OECD Economics Department Working Papers, No. 1142, OECD Publishing.

Chor, D. (2010), "Unpacking Sources of Comparative Advantage: A Quantitative Approach", Journal of International Economics, Vol. 82 (2010) 152-167.

Chor, D. and K. Manova (2012), "Off the Cliff and Back? Credit Conditions and International Trade during the Global Financial Crisis", Journal of International Economics, Elsevier, Vol. 87(1).

Cunat, A. and M. J. Melitz (2012), "Volatility, Labor Market Flexibility, and the Pattern of Comparative Advantage", Journal of the European Economic Association 10: 225-254.

Dalum, B., K. Laursen and B. Verspagen (1999), "Does Specialization Matter for Growth?", Industrial and Corporate Change, Vol. 8, Oxford University Press.

Dess, G.G., and J.D. Shaw (2001), "Voluntary Turnover, Social Capital, and Organizational Performance", Academy of Management Review, 26(3).

Eaton, J., S.Kortum, B. Neiman and J. Romalis (2011), "Trade and the Global Recession", NBER Working Papers 16666, National Bureau of Economic Research.

Egger, P., M. Larch, K.E. Staub and R. Winkelmann (2011), "The Trade Effects of Endogenous Preferential Trade Agreements", American Economic Journal: Economic Policy 3.

Emran, S. and J. Stiglitz, (2005), "On Selective Indirect Tax Reform in Developing Countries", Journal of Public Economics 89.

Escaith, H., N. Lindenberg and S. Miroudot (2010), "International Supply Chains and Trade Elasticity in Times of Global Crisis", Staff Working Paper ERSD-2010-08, World Trade Organisation. 
Feenstra R.C. and G. H. Hanson (1996), "Globalization, Outsourcing, and Wage Inequality", The American Economic Review, Vol. 86, No. 2, Papers and Proceedings of the Hundredth and Eighth Annual Meeting of the American Economic Association.

Felbermayr, G., M. Larch and W. Lechthaler (2009), "Unemployment in an Interdependent World", CESifo Working Paper, No. 2788.

Fontagné, L. and J. Fouré, (2013), “Opening a Pandora's Box: Modelling World Trade Patterns at the 2035 Horizon”, CEPII Working Paper, No. 22.

Fontagné, L. et al. (2014), “Trade Patterns in the 2060 World Economy”, OECD Economics Department Working Papers, No 1142, OECD Publishing, Paris.

Fouré, J., A. Bénassy-Quéré and L. Fontagné (2012), "The Great Shift: Macroeconomic projections for the world economy at the 2050 horizon", Working Papers 2012-03, CEPII Research Center.

Freund, C. (2009), "The Trade Response to Global Downturns: Historical Evidence”, World Bank Policy Research Working Paper, No. 5015, World Bank.

Greenwood, J. (1999), "The Third Industrial Revolution: Technology, Productivity, and Income Inequality”, Economic Review, Federal Reserve Bank of Cleveland.

Grossman, G.M. and E. Helpman (1991), "Quality Ladders in the Theory of Growth," The Review of Economic Studies, Vol. 58: 43-61.

Grossman, G.M. and E. Rossi-Hansberg (2006), "The Rise of Offshoring: It's Not Wine for Cloth Anymore", The New Economic Geography: Effects and Policy Implications, Federal Reserve Bank of Kansas City.

Grossman, G.M. and E. Rossi-Hansberg (2008), "Trading Tasks: A Simple Theory of Offshoring", American Economic Review, American Economic Association, Vol. 98(5).

Harrison, A. and A. Rodriguez-Clare (2009), "Trade, Foreign Investment, and Industrial Policy for Developing Countries", Handbook of Trade Economics.

Hausmann, R., J. Hwang and D. Rodrik (2007), "What You Export Matters”, Journal of Economic Growth, Vol.12:1-25.

Heckscher, E.F. and B, Ohlin (1991), "Heckscher-Ohlin Trade Theory", Cambridge, MA, MIT Press.

Helpman, E., and O. Itskhoki (2010), "Labor Market Rigidities, Trade and Unemployment", Review of Economic Studies, 77(3).

Hummels, D. (2007), "Transportation Costs and International Trade in the Second Era of Globalization", Journal of Economic Perspectives, Vol. 21, No. 3.

IEA (2012), “World Energy Outlook 2012”, OECD Publishing.

Johansson, $\AA$ and E. Olaberria (2014), "New Evidence on the Determinants of Industrial Specialisation", OECD Economics Department Policy Papers, No. 1112, OECD Publishing, Paris. 
Johansson, Å, P. Kowalski, E. Olaberria and D. Pellegrino (2014), "What explains the volume and composition of trade? Industrial evidence from a panel of countries", OECD Economics Department Policy Papers, No. 1128, OECD Publishing, Paris.

Johansson, Å., Y. Guillemette, F. Murtin, D. Turner, G. Nicoletti, G., de la Maisonneuve, C., Bagnoli,F., Bousquet, G., and F. Spinellie (2013), "Long-Term Growth Scenarios", OECD Economics Department Working Papers, No. 1000, OECD, Paris.

Katz, L. and K. Murphy (1992), "Changes in Relative Wages, 1963-1987: Supply and Demand Factors", Quarterly Journal of Economics, Vol. 107, No. 1, MIT Press, pp. 35-78.

Kierzenkowski, R. and I. Koske (2012), "Less Income Inequality and More Growth - Are they Compatible? Part 8. The Drivers of Labour Income Inequality - A Literature Review", OECD Economics Department Working Papers, No. 931, OECD, Paris.

Koopman, R., W. Powers, Z. Wang and S.J. Wei (2010), "Give Credit Where Credit Is Due: Tracing Value Added in Global Production Chains", NBER Working Papers 16426, National Bureau of Economic Research.

Korinek J. and P. Sourdin (2010), "Clarifying Trade Costs: Maritime Transport and Its Effect on Agricultural Trade", Applied Economic Perspectives and Policy, Vol. 32, No. 3, Oxford University Press, Oxford.

Koske, I., J. Fournier and I. Wanner (2012), "Less Income Inequality and More Growth - Are They Compatible? Part 2. The Distribution of Labour Income", OECD Economics Department Working Papers, No. 925, OECD, Paris.

Kowalski, P. (2011), "Comparative Advantage and Trade Performance: Policy Implications", OECD Trade Policy Working Papers, No. 121, OECD, Paris.

Krugman, P. (1980), "Scale Economies, Product Differentiation, and the Pattern of Trade", American Economic Review, American Economic Association, vol. 70(5).

Lanz, R., S. Miroudot and H. K. Nordås (2011), "Trade in Tasks", OECD Trade Policy Working Papers, No. 117, OECD Publishing.

Levchenko, A.A. (2007), "Institutional Quality and International Trade", Review of Economic Studies, Oxford University Press, Vol. 74(3), pp. 791-819.

Levchenko, A.A., L.T. Lewis and L.L. Tesar (2010), "The Collapse of International Trade During the 2008-2009 Crisis: In Search of the Smoking Gun”, NBER Working Paper No. 16006, National Bureau of Economic Research.

Levine, R. (1997), “Financial Development and Economic Growth”, Journal of Economic Literature. Vol. 35.

Levine, R. (2005), "Finance and Growth: Theory and Evidence", Handbook of Economic Growth, in: P. Aghion and S. Durlauf (ed.), Handbook of Economic Growth, edition 1, Vol. 1, chapter 12, Elsevier.

Los, B., M.P. Timmer and G. de Vries (2014), "The demand for skills 1995-2008: A global supply chain perspective", OECD Economics Department Working Papers, No 1141, OECD, Paris. 
Miroudot, S., R. Lanz and A. Ragoussis (2009), "Trade in Intermediate Goods and Services", OECD Trade Policy Working Papers, No. 93, OECD Publishing.

Moïse, E. and F. Le Bris, (2013), "Trade Costs: What have we Learned? A Synthesis Report", OECD Trade Policy Paper, No. 150, OECD Publishing, Paris.

Moïse, E., T. Orliac and P. Minor (2011), "Trade Facilitation Indicators: The Impact on Trade Costs", OECD Trade Policy Papers, No. 118.

Mollick, A.V. (2012), "Income Inequality in the U.S.: The Kuznets Hypothesis Revisited", Economic Systems, Elsevier, Vol. 36(1).

Nicoletti, G., S. Golub, D. Hajkova, D. Mirza and K-Y. Yoo (2003), "Policies and International Integration: Influences on Trade and Foreign Direct Investment", OECD Economics Department Working Papers, No. 359, OECD Publishing.

Nunn, N. and D. Trefler (2013), "Domestic Institutions as a Source of Comparative Advantage", NBER Working Papers No. 18851, National Bureau of Economic Research.

OECD (2003), "The Doha Development Agenda: Tariffs and Trade", OECD Policy Brief, OECD Publishing, Paris.

OECD (2005), "The Benefits of Liberalising Product Markets and Reducing Barriers to International Trade and Investment in the OECD", OECD Economics Department Working Papers, No. 463, OECD Publishing.

OECD (2010a), "Trade and Economic Effects of Responses to the Economic Crisis", OECD Trade Policy Studies, OECD Publishing.

OECD (2010b), Going for Growth, Economic Policy Reforms 2010, Chapter 5, OECD Publishing, Paris.

OECD (2011a), "Globalisation, Comparative Advantage and the Changing Dynamics of Trade", OECD Publishing, Paris.

OECD (2011b), “Divided We Stand Why Inequality Keeps Rising”, OECD Publishing, Paris.

OECD (2012a), “Mapping Global Value Chains”, TAD/TC/WP/RD(2012)9.

OECD (2012b), "Trade Policy Implications of Global Value Chains: Contribution to the Synthesis Report on Global Value Chains", TAD/TC/WP(2012)31.

OECD (2012c), Going for Growth, Economic Policy Reforms 2012, Chapter 5, OECD Publishing, Paris.

OECD (2013a), Interconnected Economies: Benefitting from global value chains, OECD Publishing, Paris.

OECD (2013b), OECD Economic Outlook No. 93, OECD Publishing, Paris.

Rajan, R.G. and L. Zingales (1998), "Financial Dependence and Growth", American Economic Review, Vol. 88, 559-586.

Rivera-Batiz, L.A. and P.M. Romer (1991), "International Trade with Endogenous Technological Change", European Economic Review, Elsevier, Vol. 35(4). 


\section{ECO/WKP(2014)32}

Van Reenen, J. (2011), "Wage Inequality, Technology and Trade: 21st Century Evidence”, Centre for

Economic Performance occasional papers, CEPOP28, Centre for Economic Performance, London School of Economics and Political Science. 


\section{APPENDIX 1: DETERMINANTS OF TRADE IN VALUE-ADDED}

1. There are conceptual differences between gross exports and exports of value-added. However, their determinants appear to be qualitatively and quantitatively similar. To illustrate this, Appendix Table 1 reports the results of additional estimations performed in this study following the methodology described in Box 6. Here the analysis compares the results obtained using yearly data of both gross exports and value-added exports from the OECD Trade in Value-Added database (TiVA), covering 57 countries and 21 manufacturing industries for 1995, 2000, 2005, 2008 and 2009. In the first column of Appendix Table 1 the dependent variable is gross exports and in the second, exports of value-added. While the size of the coefficients is slightly different, these differences are not statistically significant. Other estimates also feature similar properties but for space considerations they are not shown. These findings are consistent with a recent OECD study that estimated the determinants of export specialisation (as measured by Revealed Comparative Advantage) in gross and value-added terms, and found that the impact of the various determinants of specialisation are similar, regardless of whether specialisation is measured in gross or value-added terms (OECD, 2013a). Given that the determinants of gross exports and value-added exports appear to be similar, the report relies on estimations of gross exports as described in Box 6 as the data spans more years than value-added exports.

Appendix Table 1. Determinants of gross exports and value-added exports

\begin{tabular}{|c|c|c|}
\hline VARIABLES & $\begin{array}{l}\text { Gross } \\
\text { Exports }\end{array}$ & $\begin{array}{l}\text { Value added } \\
\text { exports }\end{array}$ \\
\hline Stock of capital per worker * intensity of capital & $\begin{array}{l}0.3959^{* * *} \\
(5.170)\end{array}$ & $\begin{array}{l}0.3347^{* * *} \\
(3.854)\end{array}$ \\
\hline Stock of high skill workers * intensity in skilled workers & $\begin{array}{l}0.0380^{* * *} \\
(4.042)\end{array}$ & $\begin{array}{l}0.0531^{* * *} \\
(5.586)\end{array}$ \\
\hline $\begin{array}{l}\text { Financial development * industry dependence on external } \\
\text { finance }\end{array}$ & $\begin{array}{c}0.0193^{* *} \\
(2.563)\end{array}$ & $\begin{array}{c}0.0121^{* *} \\
(2.642)\end{array}$ \\
\hline Distance & $\begin{array}{l}-0.8249^{* * *} \\
(-43.933)\end{array}$ & $\begin{array}{l}-0.8075^{\star \star \star} \\
(-42.561)\end{array}$ \\
\hline Contiguity & $\begin{array}{l}0.4806^{\star * *} \\
(10.945)\end{array}$ & $\begin{array}{l}0.5231^{* * *} \\
(11.844)\end{array}$ \\
\hline Common language & $\begin{array}{l}0.1249^{* * *} \\
(2.744)\end{array}$ & $\begin{array}{l}0.1194^{\star \star} \\
(2.543)\end{array}$ \\
\hline Constant & $\begin{array}{l}9.2566^{* * *} \\
(43.481)\end{array}$ & $\begin{array}{l}9.1287^{* * *} \\
(42.361)\end{array}$ \\
\hline Industry fixed effects & Yes & Yes \\
\hline Importer-year fixed effects & Yes & Yes \\
\hline Exporter fixed effects & Yes & Yes \\
\hline Observations & 90,816 & 90,816 \\
\hline
\end{tabular}

1. VAExp denotes value-added exports, with the other variables are defined as in Box 6 . 


\section{APPENDIX 2: SPECIALISATION AND WAGE INEQUALITY}

1. This Appendix briefly describes the empirical approach used to investigate the influence of skillbiased specialisation on the wage gap between skilled and unskilled labour. The empirical literature has identified a number of factors as potential explanation of wage inequality developments such as trade integration, skill-biased technological change, supply of different skills and labour market institutions (Feenstra and Hanson, 1996; Van Reenen, 2011; Kierzenkowski and Koske, 2012). Drawing on the existing literature and recent OECD work (OECD, 2011b), the influence of skill-biased specialisation on the wage gap between skilled and unskilled labour is explored by estimating a reduced-form equation according to:

$$
\log \left(\text { Wage Inequality }_{i t}\right)=\alpha+\beta S B S_{i t}+\rho \text { StockHK }_{i t}+\varphi \text { Global }_{i t}+\gamma T e c h_{i t}+\delta C V_{i t}+\theta_{i}+\theta_{t}+\varepsilon_{i t}
$$

where wage inequality is measured by the ratio of hourly compensation of high-skilled workers to lowskilled workers sourced from the World-Input Output Database (WIOD). Subscript $i$ denotes country and $t$ year. The explanatory variables include:

- $\quad S B S$ is the measure of skill-biased specialisation. High-skilled (low-skilled) specialisation is measured by country as the sum of value added of the four industries that are the most intensive in the use of high-skilled (low-skilled) labour as share of total value added. As a robustness check, the analysis uses a continuous measure of specialisation created as the weighted sum of industry value added, where the weights are each industry's skill-intensity in production. The specialisation measures are based on data from the World-Input Output Database (WIOD).

- $\quad$ StockHM is the stock of human capital measured as the share of the population with secondary and tertiary education sourced from the OECD Long-term Database.

- Global is a trade openness indicator and is measured as the ratio of the sum of exports and imports to GDP sourced from OECD Economic Outlook.

- Tech is an indicator of technology measured by total factor productivity sourced from the OECD Long-Term Database.

- $\quad C V$ is a set of control variables that may influence wage gaps including the share of female employment and the growth of GDP to capture cyclical fluctuations in aggregate demand and labour market institutions.

2. Equation 1 is estimated by a fixed-effects model with both country-specific effects $\theta_{i}$ and yearspecific effects $\theta_{t}$ to capture common global shocks and business cycle effects respectively. The dependent variable and most explanatory variables are logarithm-transformed. The estimation covers 35 low- and high-income countries over the time period 1995 to 2009.

3. Appendix Table 2 columns 1-4 report the results using the baseline specialisation measure, while columns 5-6 report the robustness results using the alternative specialisation measure. The effect of highskilled specialisation is positive and significant while the effect of low-skilled specialisation is negative and significant in all specifications, even accounting for technological change. This suggests that skillbiased specialisation in value-added contributes to explain cross-country differences in wage inequality. In line with existing evidence an increase in the supply of skilled workers is found to mitigate wage inequality. The coefficient on trade is never significant, consistent with empirical studies highlighting that 
skill-biased technological progress appears to have been more successful in explaining the rise in wage inequality than trade. Labour market settings were in general non-significant.

Appendix Table 2. Determinants of gross exports and value-added exports

\begin{tabular}{|c|c|c|c|c|c|c|}
\hline & 1 & 2 & 3 & 4 & 5 & 6 \\
\hline & Baseline & $\begin{array}{l}\text { Skill-biased } \\
\text { Specialisation }\end{array}$ & $\begin{array}{l}\text { Secondary } \\
\text { education }\end{array}$ & $\begin{array}{c}\text { TFP: } \\
\text { technical } \\
\text { change }\end{array}$ & $\begin{array}{c}\text { Skill- } \\
\text { biased } \\
\text { Specialis } \\
\text { ation }\end{array}$ & $\begin{array}{l}\text { TFP: } \\
\text { technical } \\
\text { change }\end{array}$ \\
\hline \multicolumn{7}{|l|}{ Supply of skill: } \\
\hline Stock of high skilled workers & $\begin{array}{c}-0.1730^{\star * \star} \\
(-3.807)\end{array}$ & $\begin{array}{c}-0.2011^{* * *} \\
(-4.331)\end{array}$ & $\begin{array}{c}-0.1837^{\star \star \star} \\
(-4.058)\end{array}$ & $\begin{array}{l}-0.0917 \\
(-1.580)\end{array}$ & $\begin{array}{c}-0.162^{\star * *} \\
(0.046)\end{array}$ & $\begin{array}{l}-0.077 \\
(0.055)\end{array}$ \\
\hline Stock of medium skilled workers & & & $\begin{array}{c}-0.3714^{\star \star \star} \\
(-5.535)\end{array}$ & $\begin{array}{c}-0.3317^{\star \star \star} \\
(-3.927)\end{array}$ & $\begin{array}{c}-0.297^{\star * *} \\
(0.070)\end{array}$ & $\begin{array}{c}-0.313^{\star \star *} \\
(0.089)\end{array}$ \\
\hline \multicolumn{7}{|l|}{ Specialisation } \\
\hline Specialisation in high-skilled industries & & $\begin{array}{c}0.0141^{\star \star \star} \\
(3.345)\end{array}$ & $\begin{array}{c}0.0134^{\star \star *} \\
(3.286)\end{array}$ & $\begin{array}{c}0.0163^{\star \star *} \\
(3.045)\end{array}$ & & \\
\hline Specialisation in low-skilled industries & & $\begin{array}{c}-0.0166^{\star * \star} \\
(-3.888)\end{array}$ & $\begin{array}{c}-0.0232^{\star \star \star} \\
(-5.376)\end{array}$ & $\begin{array}{c}-0.0165^{\star \star} \\
(-2.507)\end{array}$ & & \\
\hline Alternative specialisation indicator & & & & & $\begin{array}{l}0.049^{\star \star} \\
(0.020)\end{array}$ & $\begin{array}{l}0.055^{\star \star} \\
(0.026)\end{array}$ \\
\hline \multicolumn{7}{|l|}{ Controls: } \\
\hline$\overline{\text { Trade openness }}$ & $\begin{array}{l}0.0330 \\
(0.911)\end{array}$ & $\begin{array}{l}0.0220 \\
(0.625)\end{array}$ & $\begin{array}{l}0.0005 \\
(0.015)\end{array}$ & $\begin{array}{l}-0.0339 \\
(-0.850)\end{array}$ & $\begin{array}{c}0.014 \\
(0.036)\end{array}$ & $\begin{array}{l}-0.040 \\
(0.041)\end{array}$ \\
\hline Share of female in labour force & $\begin{array}{l}-0.1019 \\
(-0.566)\end{array}$ & $\begin{array}{l}-0.1867 \\
(-1.048)\end{array}$ & $\begin{array}{l}0.0325 \\
(0.183)\end{array}$ & $\begin{array}{l}0.0448 \\
(0.183)\end{array}$ & $\begin{array}{c}0.185 \\
(0.190)\end{array}$ & $\begin{array}{c}0.266 \\
(0.247)\end{array}$ \\
\hline Growth of GDP & $\begin{array}{l}0.0031^{*} \\
(1.854)\end{array}$ & $\begin{array}{c}0.0038^{* *} \\
(2.363)\end{array}$ & $\begin{array}{c}0.0048^{\star * *} \\
(3.034)\end{array}$ & $\begin{array}{l}0.0028 \\
(1.443)\end{array}$ & $\begin{array}{l}0.004^{* *} \\
(0.002)\end{array}$ & $\begin{array}{c}0.000 \\
(0.002)\end{array}$ \\
\hline GDP per capita in PPP & $\begin{array}{l}0.0093 \\
(0.233)\end{array}$ & $\begin{array}{c}-0.1244^{\star \star \star} \\
(-2.674)\end{array}$ & $\begin{array}{c}-0.0937^{\star \star} \\
(-2.056)\end{array}$ & $\begin{array}{c}-0.3835^{\star \star \star} \\
(-3.484)\end{array}$ & $\begin{array}{c}0.046 \\
(0.042)\end{array}$ & $\begin{array}{c}-0.275^{\star \star} \\
(0.112)\end{array}$ \\
\hline Technical progress & & & & $\begin{array}{c}0.3643^{* \star *} \\
(3.269)\end{array}$ & & $\begin{array}{c}0.382^{\star \star \star *} \\
(0.117)\end{array}$ \\
\hline Constant & $\begin{array}{l}0.7846 \\
(0.932)\end{array}$ & $\begin{array}{c}2.2939^{\star \star \star} \\
(2.695)\end{array}$ & $\begin{array}{l}0.9992 \\
(1.162)\end{array}$ & $\begin{array}{l}0.5800 \\
(0.482)\end{array}$ & $\begin{array}{l}-1.094 \\
(0.928)\end{array}$ & \\
\hline Observations & 524 & 524 & 524 & 420 & 524 & 524 \\
\hline R-squared & 0.173 & 0.230 & 0.271 & 0.251 & 0.206 & 0.206 \\
\hline Number of ncountry & 35 & 35 & 35 & 31 & 35 & 35 \\
\hline Country FE & Yes & Yes & Yes & Yes & Yes & Yes \\
\hline Year FE & Yes & Yes & Yes & Yes & Yes & Yes \\
\hline
\end{tabular}

z-statistics in parentheses

${ }^{\star * *} p<0.01,{ }^{* *} p<0.05,{ }^{*} p<0.1$ 


\section{APPENDIX 3: POLICY ASSUMPTIONS IN THE BASELINE}

1. The baseline macro-scenario includes the following assumptions (OECD, 2013b and Johansson et al., 2012 for details):

Monetary and fiscal policy:

- Policy interest rates continue to normalise as output gaps close and beyond that are directed to converge on a neutral real short-term rate, which in turn follows the potential growth rate of the economy.

- The target for inflation is generally taken to be $2 \%$, with the following exceptions: Australia, Poland, Iceland and Norway target 2.5\%; Chile, Hungary, Mexico and Korea target 3\%; Argentina, China, India and Russia target 4\%; Brazil, Indonesia and South Africa target $4.5 \%$; and Turkey targets $5 \%$.

- For those countries with initial gross general government debt in excess of $60 \%$ of GDP, fiscal policy is directed towards convergence on this debt level. Otherwise, for countries where debt is initially below the $60 \%$ threshold, fiscal policy is directed to stabilising the gross government debt ratio. To achieve these objectives for the debt ratio, fiscal consolidation is assumed to take place through a gradual improvement in the underlying primary balance, with a cap on consolidation in any single year of $1 / 2$ percentage point of GDP.

Structural policy:

- Recently legislated pension reforms involving an increase in the normal retirement age by 2030 are assumed to be implemented as planned, and the participation rates of older workers adjusted accordingly. In countries where no such reforms have been undertaken, retirement behaviour is assumed to reflect only effects coming from a rising education level. Beyond 2030 the share of active life in life expectancy is assumed to remain constant; thus, the legal pensionable age is implicitly assumed to be indexed to longevity.

- Structural unemployment in OECD countries gradually returns to the lowest value estimated between 2007 and 2013. Unemployment in non-OECD countries, where the level is currently above the OECD average, is assumed to gradually converge to the OECD average, while remaining unchanged in countries currently below the OECD average.

- The long-term trend increase in average years of schooling per worker is assumed to continue in all countries, and is estimated to have a modest positive effect on aggregate labour force participation.

- In countries where regulations are currently more restrictive that the average observed in the OECD area in 2011, product market and trade regulations are assumed to gradually converge towards this average regulatory stance, while for other countries they remain unchanged.

- For non-OECD countries, a gradual increase in public spending on social protection is assumed, amounting on average to an increase of four percentage points of GDP to a level of provision similar to the average OECD country. It is further assumed that this is financed in a way in which there is no effect on public saving. 
2. The baseline detailed dynamic general equilibrium framework includes the following assumptions:

- Transaction cost for goods are reduced in two stages. From 2012 and until 2035, transaction costs are assumed to gradually decline by $25 \%$. From 2035 costs are assumed to further be reduced by 20 percentage points, to decline in total by $45 \%$ in 2060 .

- A decoupling of the Common Agricultural Policy is included. Thus, support on crops and other agricultural goods and livestock are cut by $75 \%$ and $50 \%$ in 2006 , respectively.

- Implemented and agreed trade agreements including the enlargement of the European Union (EU-28), European Union-Korea, the ASEAN, the ASEAN-Australia and New Zealand, the ASEAN-China, The ASEAN-India, the ASEAN-Japan, and the ASEAN-Korea agreements are accounted for in the baseline. 


\section{APPENDIX 4: ADDITIONAL DATA}

Appendix Figure 1: Trade shares in selected industries, 2010 and 2060

$\%$ of world exports

Electronics

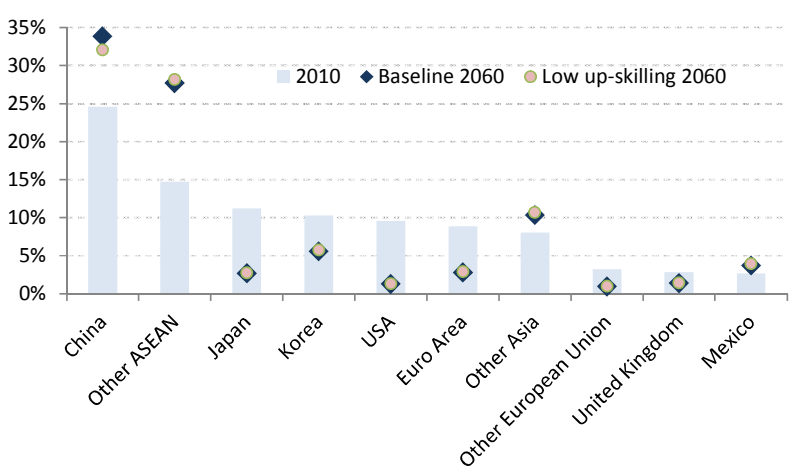

Chemicals

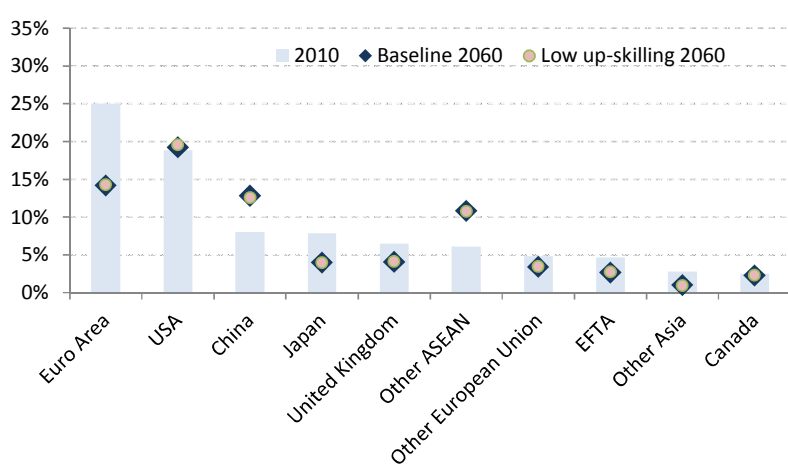

Wholesale retail

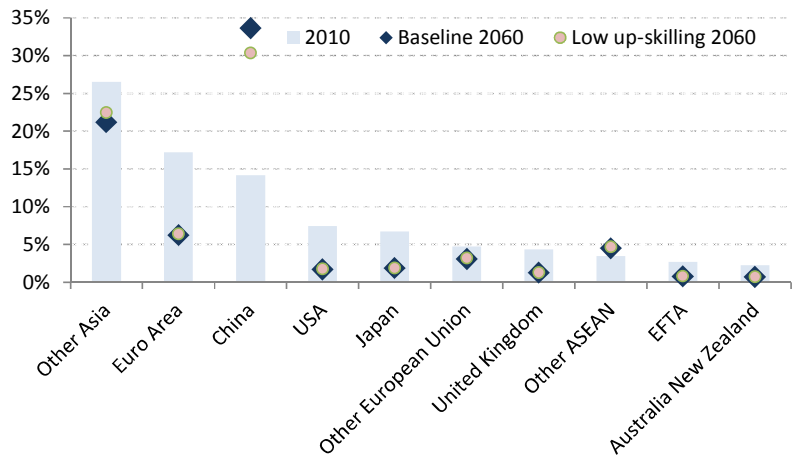

Transport equipment

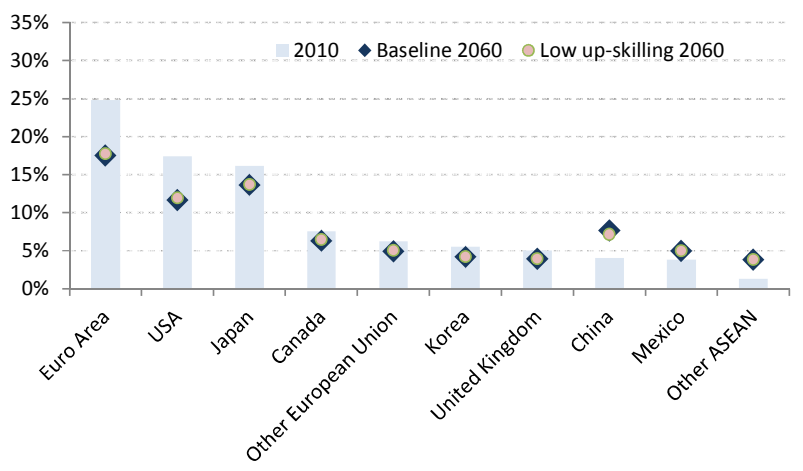

Transport services

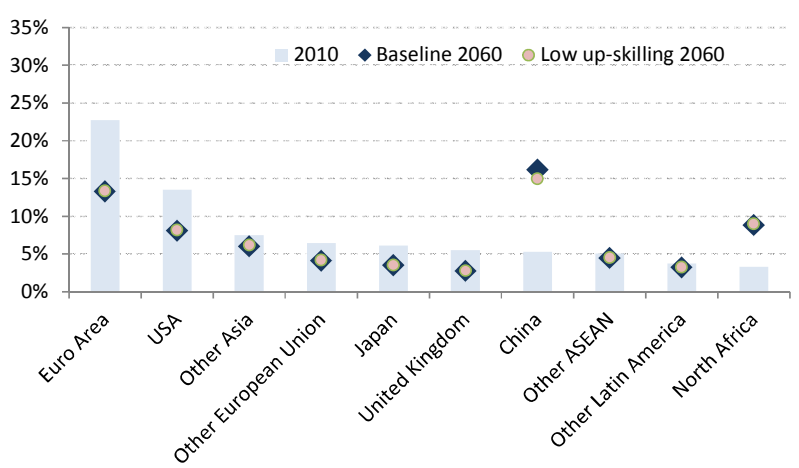

Business services

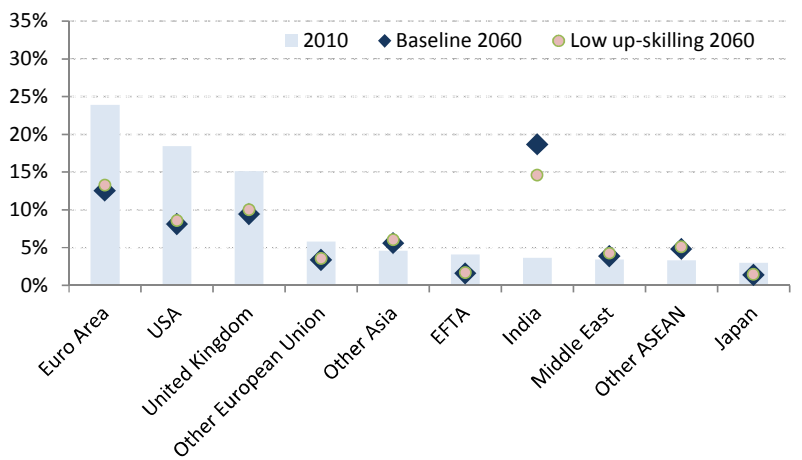




\section{WORKING PAPERS}

The full series of Economics Department Working Papers can be consulted at www.oecd.org/eco/workingpapers

1135. Consequences of climate change damages for economic growth - a dynamic quantitative assessment

(July 2014) by Rob Dellink, Elisa Lanzi, Jean Chateau, Francesco Bosello, Ramiro Parrado and Kelly de Bruin

1134. Comparing the robustness of PAYG pension schemes

(July 2014) by Falilou Fall

1133. Overcoming vulnerabilities of pension systems (July 2014) by Falilou Fall and Debbie Bloch

1132. Overcoming vulnerabilities of health care systems

(July 2014) by Mauro Pisu

1131. Overcoming vulnerability of unemployment insurance schemes

(July 2014) by Jon Pareliussen

1130. Vulnerability of social institutions: Lessons from the recent crisis and historical episodes (July 2014) by Falilou Fall, Mauro Pisu, Jon Pareliussen and Debbie Bloch

1129. An update of the OECD international trade equations (June 2014) by Myriam Morin and Cyrille Schwellnus

1128. What explains the volume and composition of trade? Industrial evidence from a panel of countries

(June 2014) by Asa Johansson, Przemyslaw Kowalski, Eduardo Olaberria and Dario Pellegrino

1127. Do resources flow to patenting firms: cross-country evidence from firm level data

(June 2014) by Dan Andrews, Chiara Criscuolo and Carlo Menon

1126. Macroprudential policy tools in Norway: Strengthening financial system resilience

(June 2014) by Yosuke Jin, Patrick Lenain and Paul O’Brien

1125. Strengthening competition in Poland

(June 2014) by Balász Égert and Antoine Goujard

1124. Making the labour market work better in Poland

(June 2014) by Hervé Boulhol

1123. Enhancing competition and the business environment in Hungary

(June 2014) by Alvaro Pina

1122. Tackling labour mismatches and promoting mobility in Hungary

(June 2014) by Stéphane Sorbe

1121. Local public finances and municipal reform in Finland

(June 2014) by Christophe André and Clara Garcia 
1120. The economic consequences of ageing: the case of Finland (June 2014) by Christine de la Maisonneuve, Christophe André, Clara Garcia and Vincent Koen

1119. Making the most of skills in Denmark (June 2014) by Stéphanie Jamet and Vincent Koen

1118. Trade specialisation and policies to foster competition and innovation in Denmark (June 2014) by Müge Adalet McGowan

1117. Policies for making the Chilean labour market more inclusive (June 2014) by Aida Caldera Sanchez

1116. Spillover effects from exiting highly expansionary monetary policies

(May 2014) by Łukasz Rawdanowicz, Romain Bouis, Jérôme Brezillon, Ane Kathrine Christensen and Kei-Ichiro Inaba

1115. Economic policies and microeconomic stability: A literature review and some empirics (April 2014) by Paula Garda and Volker Ziemann

1114. How to improve Israel's health-care system (April 2014) by Philip Hemmings

1113. How to improve taxes and transfers in Israel (April 2014) by Philip Hemmings

1112. New evidence on the determinants of industrial specialisation (April 2014) by Asa Johansson and Eduardo Olaberria

1111. Economic growth from the household perspective: GDP and income distribution developments across $O E C D$ countries (April 2014) by Orsetta Causa, Sonia Araujo, Agnès Cavaciuti, Nicolas Ruiz and Zuzana Smidova

1110. Would a growth slowdown in emerging markets spill over to high-income countries? A quantitative assessment (April 2014) By Patrice Ollivaud, Elena Rusticelli and Cyrille Schwellnus

1109. Short-term indicator models for quarterly GDP growth in the BRIICS: A small-scale bridge model approach (April 2014) by Thomas Chalaux and Cyrille Schwellnus

1108. The prudential regulation of financial institutions: why regulatory responses to the crisis might not prove sufficient

(March 2014) by William R. White

1107. OECD forecasts during and after the financial crisis: a post mortem (March 2014) by Nigel Pain, Christine Lewis, Thai-Thanh Dang, Yosuke Jin and Pete Richardson 